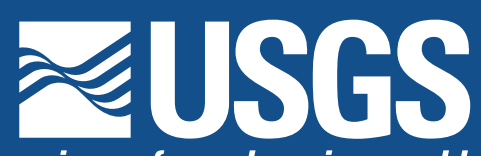

science for a changing world

National Water Quality Program

Depth of Groundwater Used for Drinking-Water Supplies in the United States

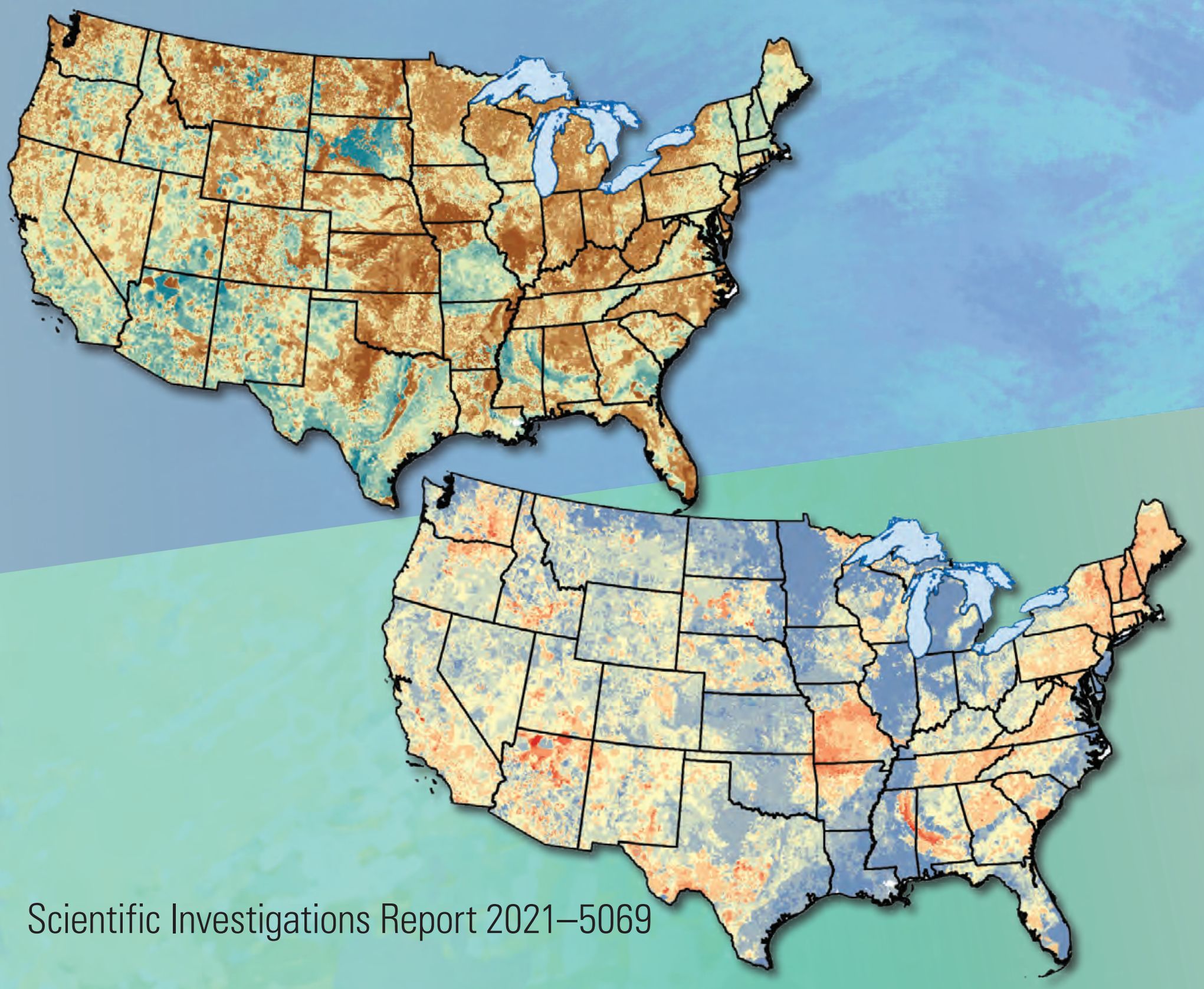

U.S. Department of the Interior

U.S. Geological Survey 
Cover. Moving median of the depth to the bottom of the open interval (top) and the open interval length (bottom) from domestic-supply wells in the conterminous United States; from figures 14 and 15 of this report. 


\section{Depth of Groundwater Used for Drinking-Water Supplies in the United States}

By James R. Degnan, Leon J. Kauffman, Melinda L. Erickson,

Kenneth Belitz, and Paul E. Stackelberg

National Water Quality Program

Scientific Investigations Report 2021-5069 


\section{U.S. Geological Survey, Reston, Virginia: 2021}

For more information on the USGS - the Federal source for science about the Earth, its natural and living resources, natural hazards, and the environment—visit https://www.usgs.gov or call 1-888-ASK-USGS.

For an overview of USGS information products, including maps, imagery, and publications, visit https://store.usgs.gov/.

Any use of trade, firm, or product names is for descriptive purposes only and does not imply endorsement by the U.S. Government.

Although this information product, for the most part, is in the public domain, it also may contain copyrighted materials as noted in the text. Permission to reproduce copyrighted items must be secured from the copyright owner.

Suggested citation:

Degnan, J.R., Kauffman, L.J., Erickson, M.L., Belitz, K., and Stackelberg, P.E., 2021, Depth of groundwater used for drinking-water supplies in the United States: U.S. Geological Survey Scientific Investigations Report 2021-5069, 69 p., https://doi.org/10.3133/sir20215069.

Associated data for this publication:

Kauffman, L.J., Degnan, J.R., Belitz, K., Stackelberg, P.E., and Erickson, M.L., 2021, Data for depth of groundwater used for drinking-water supplies in the United States: U.S. Geological Survey data release, https://doi.org/10.5066/P94640EM.

ISSN 2328-0328 (online) 


\section{Contents}

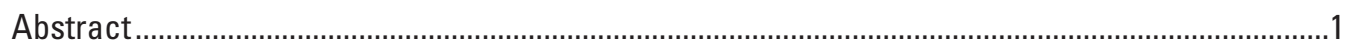

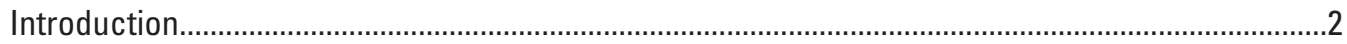

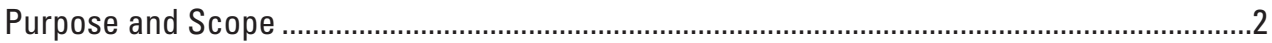

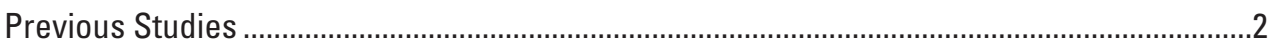

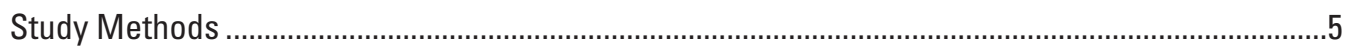

Compilation, Processing, and Quality Assurance of Well Data ................................................

Aggregation of Hydrogeologic Settings.............................................................................

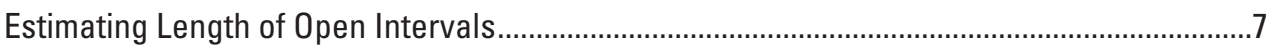

Generation of Open Interval Grids .........................................................................................

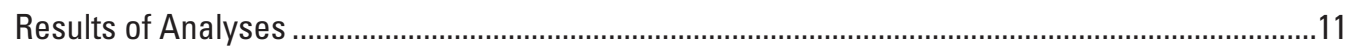

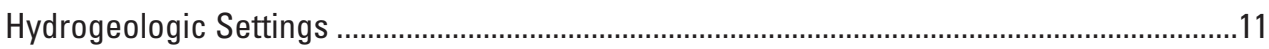

Sources and Density of Well Data ..........................................................................................

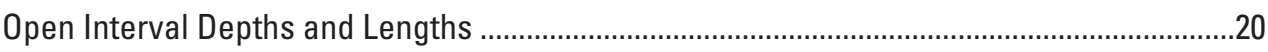

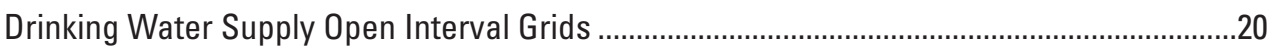

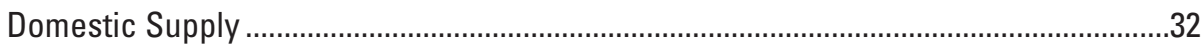

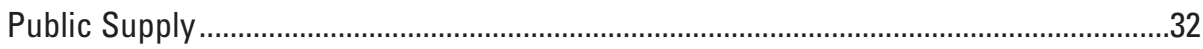

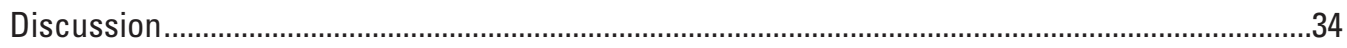

Effect of Overlying Sediment on Depths of Open Intervals in Wells ....................................34

Characteristics of Wells in Glacial Aquifer Systems ...........................................................

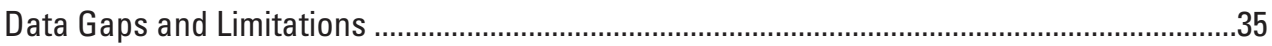

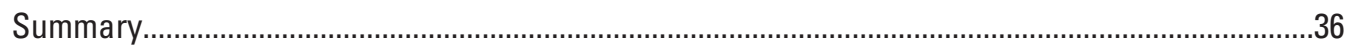

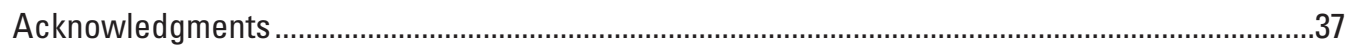

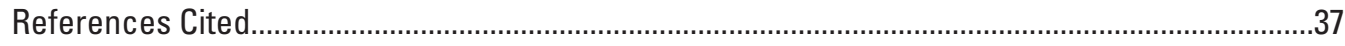

Appendix 1. Hydrogeologic Settings in Principal Aquifers and Secondary

Hydrogeologic Regions of the United States.........................................................................58

\section{Figures}

1. Maps of the conterminous United States showing principal aquifers and secondary hydrogeologic regions.................................

2. Maps showing the distance from a cell within a grid required to reach five wells with sufficient information to compute a median value for the bottom of the open interval for domestic- and public-supply wells in the conterminous United States.

3. Maps showing the distance from a cell within a grid required to reach five wells with sufficient information to compute a median value for the open interval length for domestic- and public-supply wells in the conterminous United States.

4. Maps showing examples of secondary hydrogeologic regions that were combined with principal aquifers in the Puget Sound, Colorado Plateau, and Valley and Ridge principal aquifers.

5. Map showing the locations of glacial, coarse glacial, and stream valley alluvial sediments in the conterminous United States. 
6. Pie charts showing the proportions of area with and without sediment overlying secondary hydrogeologic regions and principal aquifers in the conterminous United States.

7. Bar graphs showing the median depth to the bottom of open interval in wells used for drinking water for domestic- and public-supply wells in the conterminous United States

8. Bar graphs showing the median length of the open interval in wells used for drinking water for domestic- and public-supply wells in the conterminous United States

9. Maps showing the median depth to the top of the open interval of wells used for drinking water for each hydrogeologic setting by domestic- and public-supply wells in the conterminous United States.

10. Maps showing the median depth to the bottom of the open interval of wells used for drinking water for each hydrogeologic setting by domestic- and public-supply wells in the conterminous United States.

11. Maps showing the median length of the open interval in wells used for drinking water for each hydrogeologic setting by domestic- and public-supply wells in the conterminous United States

12. Graphs showing an example of a bimodal relation between open interval length and well depth for domestic-supply wells in the Basin and Range basin-fill aquifer.....28

13. Maps showing the moving median of the depth to the top of the open interval of domestic- and public-supply wells in the conterminous United States.

14. Maps showing the moving median of the depth to the bottom of the open interval of domestic- and public-supply wells in the conterminous United States

15. Maps showing the moving median of the open interval length of domestic- and public-supply wells in the conterminous United States.

16. Maps showing the differences between the moving median grids for depth to the top and bottom and length of the open interval in domestic- and public-supply wells in the conterminous United States.

\section{Tables}

1. Numbers of wells for which well depth and open interval data were compiled, by data source and type of well

2. Numbers of hydrogeologic settings, and area, by lithology, for principal aquifers and secondary hydrogeologic regions

3. Number and density of wells, and median values for depths to top and bottom, and lengths of open interval, by type of region and lithology for all wells and wells in hydrogeologic settings without overlying sediment for domestic- and public-supply wells.

4. Numbers of wells with median values for depth to top and bottom, and length of open interval by type of region and lithology, for wells with overlying sediment for domestic- and public-supply wells 


\title{
Depth of Ground water Used for Drinking-Water Supplies in the United States
}

\author{
By James R. Degnan, Leon J. Kauffman, Melinda L. Erickson, Kenneth Belitz, and Paul E. Stackelberg
}

\section{Abstract}

Groundwater supplies 35 percent of drinking water in the United States. Mapping the quantity and quality of groundwater at the depths used for potable supplies requires an understanding of locational variation in the characteristics of drinking-water wells (depth and open interval). Typical depths of domestic- and public-drinking-water supply wells vary by and within aquifer across the United States. The depths to the top and bottom of the zones from which drinking water is withdrawn are important predictor variables in regional- and national-scale statistical water models, but spatially extensive maps of the depths to drinking-water-supply sources are not consistently available in modeled regions. Therefore, it was necessary to generate a set of grids representing surfaces of the approximate common depth and length of open intervals in the wells from which water is withdrawn for domestic- and public-drinking-water supply (withdrawal zones) within the conterminous United States.

Well data (about 7.6 million records) were compiled from several sources, including the U.S. Geological Survey's National Water Information System (600,922 records), the U.S. Environmental Protection Agency's Safe Drinking Water Information System dataset (66,540 records, primarily public-supply wells), a groundwater ambient monitoring dataset (31,448 records, primarily domestic-supply wells), individual State data $(6,096,503$ records), a national brackish aquifer study $(96,885$ records), and a glacial aquifer study (729,564 records).

Fifty-seven principal aquifers and 65 secondary hydrogeologic regions have been designated in the conterminous United States. The principal aquifers and secondary hydrogeologic regions vary in depth, thickness, lithology, and transmissivity characteristics. Some principal aquifers underlie secondary hydrogeologic regions, and may in turn be overlain by glacial sediment or basin and valley fill aquifers, which may also be used as drinking-water sources. The principal aquifer and secondary hydrogeologic region polygons were merged with overlying sediment polygons, where present, including glacial sediment, coarse glacial sediment, and stream valley alluvium (alluvium) polygons, to generate unique hydrogeologic settings across the conterminous United States. A total of 288 distinct hydrogeologic settings resulted from the merging of principal aquifer, secondary hydrogeologic region, glacial sediment, coarse glacial sediment, and alluvium polygons.
Each well was assigned to a hydrogeologic setting on the basis of location. Hydrogeologic setting well groupings were used to guide calculations of the median value for well depth and depth to and length of open intervals across the hydrogeologic setting. Where well data were sparse or missing, wells from hydrogeologic settings with similar well construction properties, geology, physiography, and topography were grouped and used to calculate the moving median depth (if less than five wells in a 100-kilometer [62.1-mile] radius) and to estimate open interval length (if not available within hydrogeologic setting). Grids were generated to represent what might be considered as the "typical" or "median" domestic- and public-supply well in an area. The well properties are defined with moving median grids of top depth, bottom depth, and length of open interval at a 1-square-kilometer (0.38-square-mile) grid cell scale.

Median depths and open intervals of domestic- and public-supply wells varied by lithology of the hydrogeologic setting and overlying sediment. Overall, the median depths were 142 feet (43.3 meters) for all domestic-supply wells and 202 feet (61.6 meters) for all public-supply wells. The median open intervals were 21 feet (6.4 meters) for domestic-supply wells and 49 feet (14.9 meters) for public-supply wells. The shallowest median bottom open interval depths for domesticsupply wells were in the secondary hydrogeologic regions with coarse glacial sediment, which suggests that the wells are most commonly completed in the permeable coarse glacial sediment and not in the underlying secondary hydrogeologic region. Public-supply wells were completed at relatively shallow median depths when drilled in permeable sediment that overlie secondary hydrogeologic regions. When public-supply wells were completed in principal aquifers, the median depths were typically greater than wells completed in secondary hydrogeologic regions.

Well data used in this study were limited to those available from national or State digital databases. Several qualityassurance checks were performed during data compilation, but a comprehensive quality assurance inspection for each of the data sources was outside the scope of this study. Grids defining typical open intervals in domestic- and public-supply wells are presented. Although there are many places where multiple aquifers are stacked, these results correspond primarily to the aquifer with the highest documented number of wells for each use. 


\section{Introduction}

Worldwide, groundwater supplies 50 percent of drinking water (Zekster and Everett, 2004), and in the United States, it supplies 35 percent of drinking water (Dieter and others, 2018). The use of groundwater as a potable supply is limited, however, where its quality is adversely affected by anthropogenic and geogenic contaminants (Nordstrom, 2002; Foster and Chilton, 2003). Mapping the quantity and quality of groundwater at the depths from which it is pumped from domestic- and public-supply wells requires an understanding of the characteristics of these well types, such as the depths and lengths of their open intervals (whether through a well screen or an open borehole) in aquifers and the water-bearing rocks or unconsolidated materials in which the wells are completed. The presence of geogenic contaminants varies, in part, by aquifer depth and type across the United States (Ayotte and others, 2011), and thus the variability in the depth of domesticand public-supply wells used for drinking water is of concern for resource and consumer protection and for the assessment of data gaps (Yager and others, 2018).

Depths to the top and bottom of open intervals in wells from which water is withdrawn for drinking water are important variables in statistical models used to predict groundwater quality regionally (Ayotte and others, 2016; Ransom and others, 2017; Rosecrans and others, 2017a, b, 2018; Erickson and others, 2018), and across the United States (Nolan and Hitt, 2006; Ayotte and others, 2017; Stanton and others, 2017). Several regional- and national-scale machine-learning models are being developed for the purpose of making water-quality predictions and maps of the depths relevant to drinking water supply (for example, Ransom, 2019; Erickson and others, 2021). Spatially extensive maps of depths to groundwater used for drinking-water supplies are not consistently available in modeled regions. Therefore, it was necessary to generate a set of grids that represent the surfaces of the approximate depth and length of the open interval of a typical well used for drinking-water supply (withdrawal zone) across the conterminous United States. Depending on the lithology of the material in which a well is completed, the open interval may represent a well screen (generally in unconsolidated rock) or an open borehole (generally in consolidated rocks). Both well depth and open interval vary by the type of water use, the hydrogeology, and the type of well (screened or open borehole), so it was important to separately define the domestic-supply withdrawal zone and the public-supply withdrawal zone.

The objectives of the study described here were to (1) inventory well-construction data, (2) inventory top depth, bottom depth, and length of open intervals of wells on a regional scale, (3) estimate missing open intervals, and (4) generate moving median grids of top depth, bottom depth, and lengths of open intervals of typical domestic and public-supply wells across the conterminous United States. This study is presented in the context of hydrogeologic settings (fig. 1), which are an aggregate of a principal aquifer (U.S. Geological Survey, 2003) or a secondary hydrogeologic region (Belitz and others, 2019b) with overlying sediment (if present). Hydrogeologic settings were used as a way of grouping wells that might be expected to be similar.

\section{Purpose and Scope}

This report describes the data sources and the methods used to gather and summarize the data on the typical depth to groundwater used for drinking-water supplies in the conterminous United States. Depths to the top and bottom of the open intervals of wells used for drinking water are important variables in statistical models used to predict groundwater quality (Rosecrans and others, 2017a). Such statistical modeling studies use continuous grid maps of variables to generate maps of water quality and contaminant conditions. A coast-to-coast set of continuous grids representing depths of open intervals in typical wells were generated to help facilitate the modeling efforts. The grids are presented as static map figures and interactive maps in this report; data are available in Kauffman and others (2021).

\section{Previous Studies}

Well depth and aquifer depth were identified as significant statistical variables in models of groundwater quality in previous regional and national modeling efforts, but spatially extensive maps of depths to drinking-water supplies are not consistently available in modeled regions. Degradation of drinking-water quality from high arsenic concentrations was found to increase with depth in North Carolina, but maps of spatially varying depth were cited as a limitation and future research area in a statewide modeling effort (Kim and others, 2011). Depth to the drinking water supply was an influential variable in a multicounty arsenic modeling effort in the glacial aquifer in north-central United States (Minnesota), but only regional-scale median depths were available for probability mapping (Erickson and others, 2018). Detailed aquifer depth information subsequently became available (Yager and others, 2018), however, and was an important variable for more recent preliminary mapping of high concentrations of arsenic and manganese in glacial aquifers across the northern United States (Erickson and others, 2021). A national study using a logistic regression to develop probability maps of high concentrations of arsenic identified the depths of domestic wells and aquifers as data gaps (Ayotte and others, 2017). Depths of domestic- and public-supply wells commonly were similar, but public-supply wells were generally deeper, such as in the High Plains principal aquifer (Bruce and Oelsner, 2001) and in a four-State study of well characteristics and arsenic concentrations (Erickson and Barnes, 2005). A study covering the entire glaciated region of the United States also found that depths of domestic- and public-supply wells were similar, but in hydrogeologic terrains where sediments are thickest, publicsupply wells were deeper (Erickson and others, 2019). 


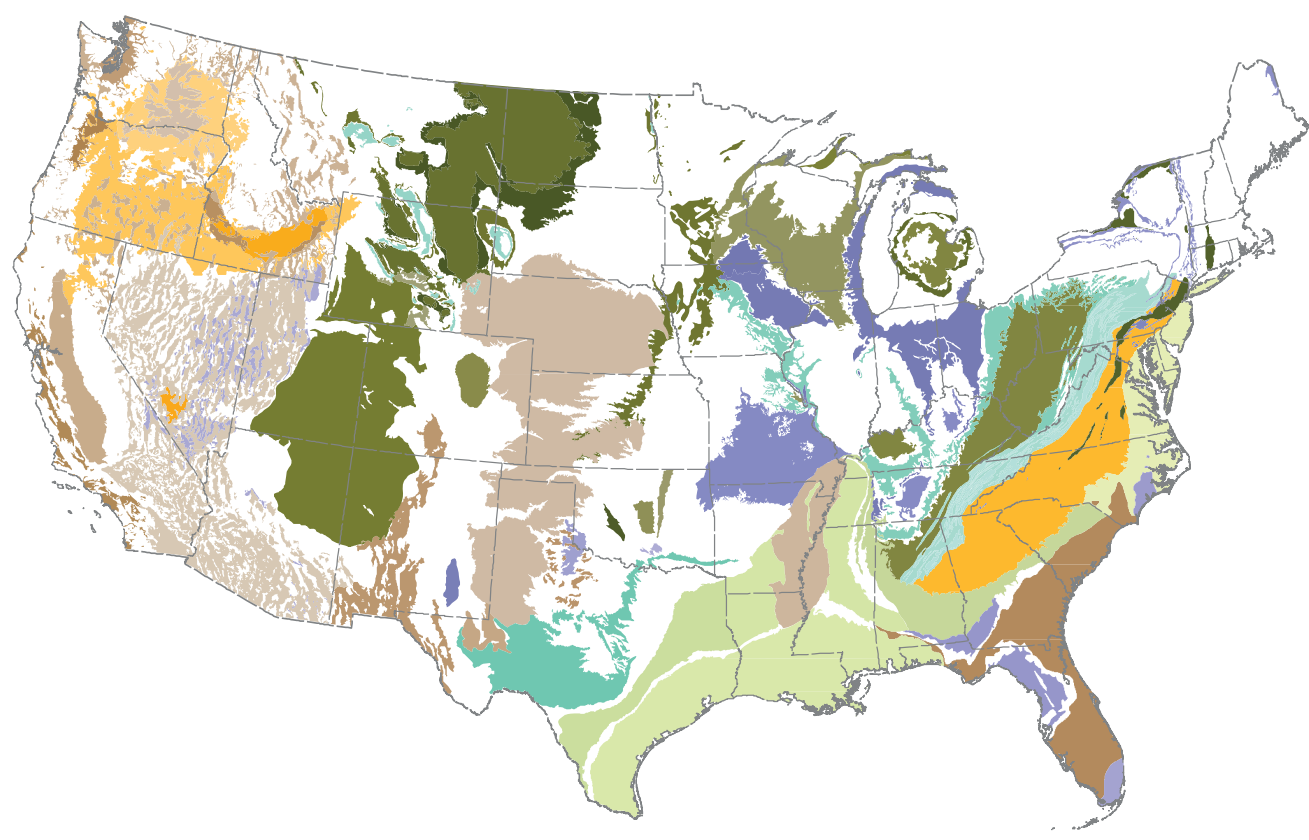

B

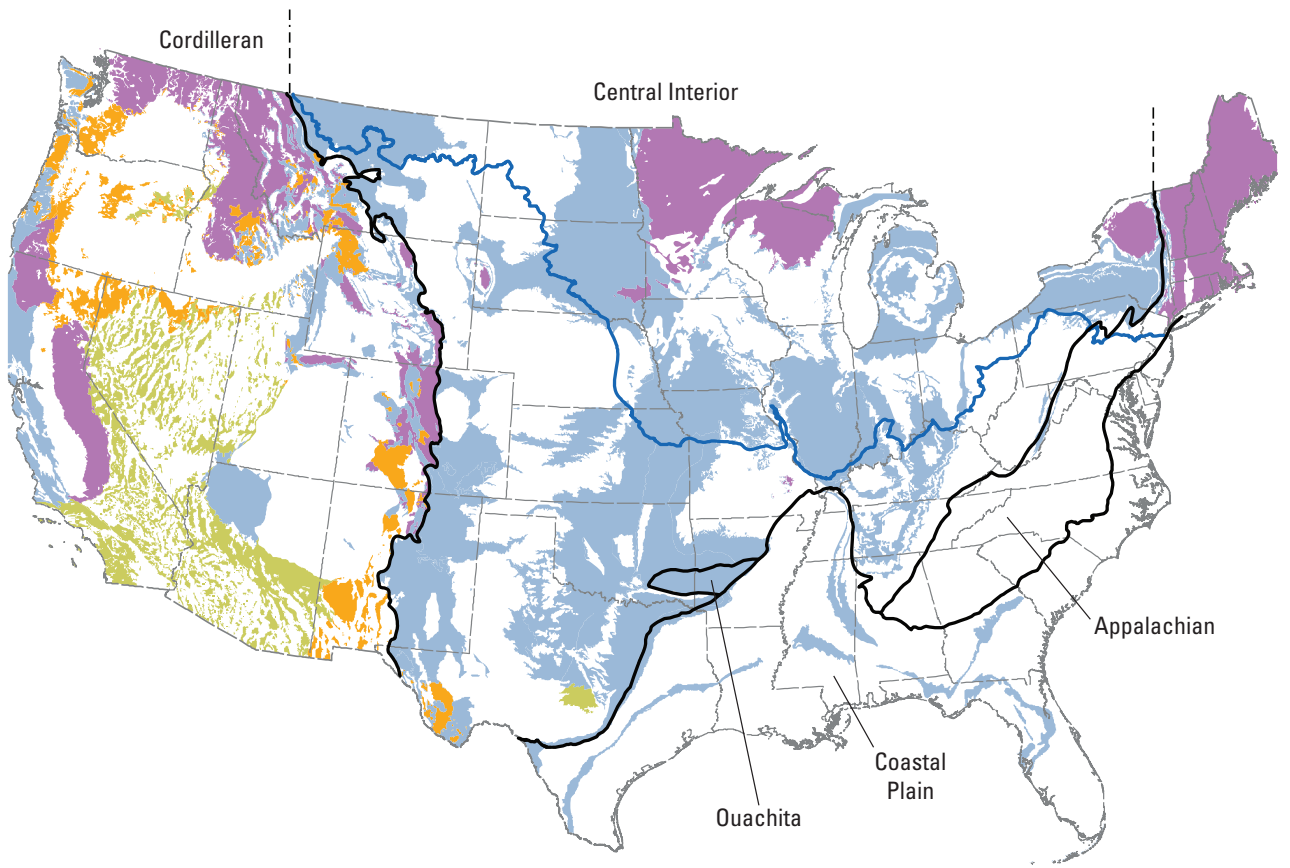

EXPLANATION

General lithology of principal aquifer

Unconsolidated sand and gravel aquifer

Semiconsolidated sand and gravel aquifer

Sandstone aquifer

Sandstone and carbonate rock aquifer

Carbonate rock aquifer

Igneous and metamorphic rock aquifers
EXPLANATION

General lithology of secondary hydrogeologic region

Crystalline

Mixed

Sedimentary

Volcanic

Geologic province boundary with province name

Southern most extent of Laurentide ice sheet

Figure 1. Maps of the conterminous United States showing $A$, principal aquifers, categorized by general lithology (shading differentiates individual principal aquifers) and $B$, secondary hydrogeologic regions classified by primary lithology (modified with permission from Belitz and others, 2019b). 
Nationwide, depths to productive aquifers that supply potable water are inherently variable, as has been described in several publications, for example, U.S. Geological Survey (2003). The 57 principal aquifers and 65 secondary hydrogeologic regions identified in the conterminous United States differ in depth, thickness, lithology, and transmissivity characteristics. Some secondary hydrogeologic regions overlie principal aquifers, and both are sometimes overlain by glacial sediment or basin and valley fill, which also may be used as drinking-water supply sources. The likelihood of encountering brackish groundwater is also depth-dependent across most of the country, with deeper wells more likely to yield water containing high concentrations of dissolved solids (Stanton and others, 2017). All these factors can influence the depth and length of the open intervals of wells.

Semiconsolidated sand aquifers are common along the southern and eastern coastal regions of the United States, including the coastal lowlands aquifer system along the gulf coast and the North Atlantic Coastal Plain aquifer system along the central Atlantic coast. These aquifer systems are composed of semihorizontal layers that comprise multiple semiconsolidated sand aquifers interbedded with aquitards, and the layers can have spatially varying thicknesses and depths. For example, the North Atlantic Coastal Plain aquifer system has thin and shallow layers to the west that become thicker and deeper to the east (Masterson and others, 2016). Additionally, hydrologic and water-quality characteristics can vary within each aquifer layer, resulting in variability in the typical depths of the layer developed for different types of water use, whether domestic or public supply (Brown and others, 2019; Degnan and others, 2020).

Sandstone, sandstone and carbonate, and carbonate principal aquifers and secondary hydrogeologic regions are present throughout the country, with principal aquifers generally having hydrogeologic properties more conducive to larger well yields and water-supply volumes (Miller, 1999). Examples in the western part of the country include the Colorado Plateaus aquifers (Robson and Banta, 1995), the upper Tertiary aquifers, and the coast ranges secondary hydrogeologic regions (Belitz and others, 2019b). In the central part of the country examples include the Cambrian-Ordovician aquifer system, the Ozark Plateaus aquifer system, and interior Permian secondary hydrogeologic region. The Pennsylvanian aquifers, the Floridan aquifer system, and the gulf coastal secondary hydrogeologic region are examples in the eastern and southeastern parts of the country (Miller, 1990). These aquifers and aquifer systems commonly are layered sedimentary units that include low permeability confining or semiconfining units between aquifers. Water quality and hydraulic conductivity can vary spatially and with depth, and parts of the aquifer systems contain highly mineralized water or have relatively low permeability. Carbonate rocks can have intergranular porosity as well as significant secondary porosity from large solution openings such as channels that resulted from dissolution weathering.
Crystalline or volcanic principal aquifers and secondary hydrogeologic regions are present primarily in the northwestern, western, north-central, and northeastern parts of the country. Examples include the basaltic-rock aquifers of the Pacific Northwest and the Columbia Plateau, the Sierra Nevada, the Canadian Shield, and the Northern Appalachian Mountains secondary hydrogeologic regions. The thickness and hydrologic characteristics of these aquifers vary greatly based on the nature of the environment of placement (for example, volcanic ash fall as opposed to volcanic flows) and the age, degree of weathering, and fracturing of the rocks.

Unconsolidated basin and valley fill overlying some principal aquifers are composed of sand and gravel deposits, sometimes interbedded with fine-grained materials. These overlying sediment aquifers can be spatially extensive and vary in thickness and hydrologic properties. Examples include California's Central Valley, the Basin and Range in the southwestern United States, and the High Plains Aquifer in the central United States. The typical depths of the aquifers used for water supply vary with water table depth, type of water use, and water capacity requirements (Miller, 1999).

In the northern part of the United States, within the glaciated areas that cover parts of 24 States, glacial sediments can be an important source of drinking water. The thickness and hydraulic conductivity of glacial sediments vary from very thin coverage (meters) in the Northeast and in areas with significant topographic relief to very thick (tens to hundreds of meters) in the Midwest and in far western Washington (Yager and others, 2018; Erickson and others, 2019). Large areas of the northeastern United States rely on thin, discontinuous till and fractured bedrock for drinking water supplies. Thick deposits of permeable stratified sediments in the southern part of the glaciated area, along the coasts, and in narrow valleys throughout are also developed for drinking-water supplies.

Machine-learning water-quality models of constituents of concern are in development for several important drinkingwater aquifers in the glacial aquifer systems in the northern United States, with the goal of mapping water quality at depths relevant to drinking-water supply (Stackelberg and others, 2021). Several preliminary or published national- and regional-scale groundwater quality models found that depth was an influential model predictor. One study (Ransom, 2019) found that predicted nitrate concentrations across the United States are dependent upon depth. Another study (DeSimone and others, 2020) found that predicted $\mathrm{pH}$ and redox conditions were depth dependent in the North Atlantic Coastal Plain aquifer system, and a study in California (Rosecrans and others, 2017b) found that depth was an important predictor variable for redox conditions in the Central Valley. In the glacial aquifers system in the Midwest, anoxic redox conditions and high concentrations of arsenic and manganese were more likely at deep depths (Erickson and others, 2021). Another study (Stackelberg and others, 2021) generated depth to drinking-water supply grids to help predict $\mathrm{pH}$ in the glacial aquifer system and mapped $\mathrm{pH}$ predictions at typical domestic- and public-drinking-water supply depths. 
Thus, the depth to the withdrawal zone in wells that supply drinking water differs across the country because of the inherent variability in the characteristics and conditions of hydrogeologic settings. A national-scale grid of typical depths for domestic- and public-drinking-water supply will allow better local, regional, and national-scale predictions and mapping of areas of concern or hazards to sources of drinking water.

\section{Study Methods}

The depths to open intervals in drinking-water supply wells vary by aquifer and region, and the availability and reliability of the information can be expected to vary by dataset and source. The open interval is defined as the length and top and bottom depth of zone within a well from which water is withdrawn through a well screen or open borehole. The well depth is the bottom of the completed well, which is not always as deep as the original hole depth. Hole depth is always the same or deeper than well depth. Hydrogeologic settings were aggregated from existing aquifer information and used to organize and interpret results. Missing values for depth to the top and lengths of open intervals were estimated on the basis of information gleaned from analysis of combinations of well depth and screen depth and length for each defined hydrogeologic setting. Grids describing the open intervals of typical domestic- and public-supply wells were developed from the processed data for the wells.

\section{Compilation, Processing, and Quality Assurance of Well Data}

Well construction and location data were compiled from records for about 7.2 million domestic wells and 428 thousand public-supply wells across the conterminous United States. The data were obtained from several sources, including the National Water Information System (NWIS; U.S. Geological Survey, 2019), a national brackish aquifer study (Stanton and others, 2017), a glacial aquifer study (Bayless and others, 2017), and many individual State datasets (table 1). The individual State data commonly included information from wellconstruction databases developed from drillers' logs. In addition to individual State datasets, State data were also a part of the USGS National Water-Quality Assessment (NAWQA) Project's National Groundwater Aggregation database (NGA), which included data from the Safe Drinking Water Information System (U.S. Environmental Protection Agency, 2013) from each State and ambient groundwater monitoring programs. The diverse nature of data sources required standardization of data fields used to store information about well construction. To that end, the interrelated NWIS data fields such as casing

Table 1. Numbers of wells for which well depth and open interval data were compiled, by data source and type of well.

[National Water Information System (NWIS) data are from U.S. Geological Survey (2019); glaciated data are from Bayless and others (2017); National Groundwater Aggregation (NGA) and individual State data are from Kauffman and others (2021); brackish data are from Stanton and others (2017). \%, percent]

\begin{tabular}{|c|c|c|c|c|c|}
\hline \multirow{3}{*}{ Data source } & \multicolumn{2}{|c|}{ All wells, number of wells } & \multicolumn{3}{|c|}{ After duplicates removed } \\
\hline & \multirow{2}{*}{ With depth } & \multirow{2}{*}{ With open interval } & \multicolumn{2}{|c|}{ Number of wells } & \multirow{2}{*}{$\begin{array}{l}\text { Percentage of wells, with } \\
\text { open interval }\end{array}$} \\
\hline & & & With depth & With open interval & \\
\hline \multicolumn{6}{|c|}{ Domestic-supply wells } \\
\hline NWIS & 523,719 & 293,143 & 417,228 & 227,552 & $54.50 \%$ \\
\hline Glaciated & 683,552 & 274,972 & 298,079 & 142,734 & $47.90 \%$ \\
\hline NGA & 31,448 & 2,164 & 11,474 & 1,259 & $11.00 \%$ \\
\hline Brackish & 73,003 & 26,488 & 30,747 & 11,884 & $38.70 \%$ \\
\hline Individual State data & $5,881,441$ & $3,640,523$ & $4,979,594$ & $3,105,800$ & $62.40 \%$ \\
\hline Total & $7,193,163$ & $4,237,290$ & $5,737,122$ & $3,489,229$ & $60.80 \%$ \\
\hline \multicolumn{6}{|c|}{ Public-supply wells } \\
\hline NWIS & 77,203 & 48,502 & 63,106 & 40,675 & $64.50 \%$ \\
\hline Glaciated & 46,012 & 31,275 & 28,892 & 19,898 & $68.90 \%$ \\
\hline NGA & 66,540 & 14,871 & 33,875 & 9,204 & $27.20 \%$ \\
\hline Brackish & 23,882 & 13,343 & 10,237 & 5,191 & $50.70 \%$ \\
\hline Individual State data & 215,062 & 114,748 & 184,380 & 99,415 & $53.90 \%$ \\
\hline Total & 428,699 & 222,739 & 320,490 & 174,383 & $54.40 \%$ \\
\hline \multicolumn{6}{|c|}{ All wells } \\
\hline Total & $7,621,862$ & $4,460,029$ & $6,057,612$ & $3,663,612$ & $60.50 \%$ \\
\hline
\end{tabular}


length, open interval length, depth to the bottom and top of open interval, depth of well bottom, and depth of hole bottom were used to hold appropriate data from other databases. This resulted in different data-collection and preservation protocols, which in turn led to data standardization procedures necessary for this study. Data and statistics from different sources were reviewed, processed, and combined into domestic- and publicsupply datasets. Data sources, the fields used to define the standardized descriptions of the open intervals (top and bottom depths and total length), and summary statistics are published in Kauffman and others (2021). Automated data-quality checks included scripts to compare well construction and location information and to identify duplicates for removal. Duplicates were defined as wells within the same 328 by $328 \mathrm{ft}$ (100 by $100 \mathrm{~m}$ ) grid cell with the same reported bottom depth of the open interval. In cases where duplicates were identified, one of the wells was kept (with preference given to a record containing the depth to the top of the open interval), and the remainder were removed.

Among the various data sources, different types of data fields, field names, and levels of data consistency existed. For each data source, fields were evaluated and prioritized for defining, insofar as possible, the depth to the top and bottom of the open interval. An algorithm was developed to create, prioritize, and populate commonly named fields for the characteristics of open intervals. The depth to the bottom of the open interval was populated first because, in some instances, that value was used to compute the depth to the top of the open interval. When populating the depth to the bottom of the open interval, fields directly related to the bottom depth of the screen or open hole were used whenever provided. If those data were not available, then the information on total well depth was used, followed by information on hole depth. In NWIS, hole depth is equal to or greater than the finished well depth (U.S. Geological Survey, 2019). Fields directly related to the top of the screen or open hole were used first to populate the depth to the top of the open interval. If those data were not available, the depth to the top of the open interval was calculated by subtracting a reported screen or open hole length from the bottom depth. If those data fields were not available, the reported bottom casing depth or length was used. A field defining the open interval length was populated by calculating the difference between the bottom depth and top depth of the open interval. If fields for the top depth or the open interval were not available, the open interval was estimated as described in the "Estimating Length of Open Intervals" section of this report. If a bottom depth was not available, that well was not included in the dataset.

A series of quality-assurance and decision steps were implemented to identify and correct processing errors resulting from differences in the way the various data sources describe the top and bottom depths of the open interval. The process of digitizing well records can lead to transcription errors or misinterpretations of what is recorded on the paper records; these data checks were an attempt to minimize this type of error, but some errors will still remain in the final dataset. In cases in which a scanned version of the well records was available, it appears that the open interval length was at times recorded as the depth to the bottom of the open interval (usually a screen). The quality-assurance steps, in order of how they were implemented to compile the final data, were as follows.

1. If the preferred method of identifying and populating the bottom of the open interval field resulted in a depth value that was four times less than that obtained by using an alternative method (for example well depth or hole depth), then the deeper measurement was used.

2. If the bottom depth was less than the top depth and the alternative value of bottom depth was greater than the top depth, then the alternative value of bottom depth was used to populate the field.

3. If the top depth was greater than the bottom depth and the top depth was equal to the alternative bottom depth, then it was assumed that the bottom and top depths were switched so they were reversed.

4. If the bottom depth was less than 20 feet (ft) and the top depth was greater than $20 \mathrm{ft}$, then the top depth was used for the bottom depth and the top depth was set to null.

5. If the top depth was greater than the bottom depth and none of the above conditions were met, then the top and bottom depths were reversed.

\section{Aggregation of Hydrogeologic Settings}

Polygonal areas coincident with boundaries of previously defined principal aquifers (U.S. Geological Survey, 2003) and secondary hydrogeologic regions (Belitz and others, 2019b) were merged with polygons representing areas of permeable overlying sediment, where present, including those representing glacial sediment, coarse glacial sediment, and stream valley alluvium (alluvium), to generate unique hydrogeologic settings across the conterminous United States. The intent of these unique hydrogeologic settings was to differentiate areas on the basis of expected depth of drinking water supplies. Maps of glacial deposits, on which stratified-coarse material was differentiated, were originally developed to support regional productivity and water-quality mapping efforts (Bayless and others, 2017; Haj and others, 2018; Yager and others, 2018). The alluvium polygons were defined in areas south of the maximum extent of glaciation that were mapped either as alluvial sediments or coarse-grained proglacial sediments (Soller and others, 2009). Geographic information system (GIS) polygon files of all hydrogeologic settings are from Kauffman and others (2021).

Each well was assigned to a hydrogeologic setting on the basis of its location, and hydrogeologic setting well groupings were used to assess well depth and open interval data. Open intervals were estimated on the basis of data from within the hydrogeologic setting where a well was located, as described 
below. When well data were sparse or missing, wells from hydrogeologic settings with similar well construction properties, geology, physiography, and topography were grouped for depth or open interval analysis.

In many instances, well records did not include enough information to directly determine the open interval length. In all cases, however, the records selected contained data on depths to the bottom of the open interval, well, or hole. Cumulative distribution functions (CDFs) of the lengths of open intervals in nearby or adjacent wells with known or calculated open interval lengths were used to estimate open intervals for wells without those data. This procedure was followed only if data on the depth to the bottom of the open interval and on the geologic setting at adjacent wells were sufficiently similar. For example, the Mann-Whitney-U test (Mann and Whitney, 1947; Helsel and Hirsch, 2002) was used to determine if the CDFs of bottom depths of the open intervals for one hydrogeologic setting were similar to those for a hydrogeologic setting with missing open interval length data. Three tests were computed for each pair of CDFs using the function mannwhitneyu (SciPy, 2020): the first test compared the two CDFs directly with a two-sided test; a one-sided test was done to see if the CDF being compared was less than 90 percent of the base CDF; and the third test was done to determine if the $\mathrm{CDF}$ being compared was greater than 110 percent of the base CDF. A $p$-value of 0.05 was used to indicate statistical significance.

\section{Estimating Length of Open Intervals}

Data for either the bottom of the open interval or the total well depth were available in the records for all wells that were included in the analyses for this report. In 41 percent of the records, data for the length of the open interval were missing. The length of the open interval was estimated when the value was missing and also when there was no information on the depth to the top of the open interval from which a length could be calculated. A relation between the bottom depth and length of the open interval was defined for each hydrogeologic setting by a two-slope linear function (described in detail in this section) developed on the basis of data for wells for which both bottom depth and length data were available. When well records did not include the length of the open interval, the value was estimated using the two-slope linear function for the hydrogeologic setting and the bottom depth of the open interval for each well.

Four parameters described the two-slope linear function used to represent the relation between the depth of the bottom of the open interval $(b)$ to the length of the open interval $(l)$. The first parameter was the y-intercept $\left(l_{0}\right)$, which had to be a value of 1 or greater. The second and third parameters were the slope values for each of the two linear segments $\left(m_{1}\right.$, $m_{2}$ ). Both slopes had to be greater than 0 , and the slope of the second segment had to be greater than the first. The final parameter is the breakpoint $(s)$ where the second line begins. For $\mathrm{b}<\mathrm{s}$,

$$
l=l_{0}+m_{1} b, \text { and }
$$

for $b>s$,

$$
l=l_{0}+m_{1} s+m_{2}(b-s) .
$$

The data points were split into bins to minimize the effect of outliers in fitting a line to the data. Median values of each bin were used in the fitting process. The number of bins varied based on the number of data points. If there were more than 10,000 data points, the number of bins was calculated as the square root of the total number. For data points numbering between 500 and 10,000, 100 bins were used. For data points numbering between 31 and 500, the number of bins was calculated by dividing by 3 and converting to an integer. More than 30 data points were required to fit a line.

An equation to describe the relation between the bottom depth and the length of the open interval was defined separately for domestic- and public-supply wells for each hydrogeologic setting. When fewer than 30 data points were available in a hydrogeologic setting, additional data points were added from neighboring hydrogeologic settings that were similar (CDFs were within 10 percent). If there were still fewer than 30 points after adding points from similar neighbors, the relation was based on all the wells in hydrogeologic settings with the same lithology and overlying sediment type.

\section{Generation of Open Interval Grids}

An empirical approach was used to create grids that represent the surfaces of open intervals of a "typical" well. In this report, maps of grids (also known as rasters) are used to represent surfaces of the depths to the top and bottom and the lengths of the open intervals in domestic- and public-supply wells from which drinking water is withdrawn. Data from well records were used to map open intervals of wells by hydrogeologic setting across the conterminous United States. Each grid cell was assigned a hydrogeologic setting value from the center of the cell. A moving-median algorithm was used to create the grids because it functions as a smoothing algorithm on the individual data points, minimizing the effect of outliers.

Three moving-median open interval grids were generated for a 1-kilometer (km; 0.62-mile [mi]) grid across the conterminous United States for both public- and domestic-supply wells. A minimum target of five wells was used to compute the median value assigned to each cell and for each grid. Initially, all the wells in a cell that belonged to the same hydrogeologic setting as the cell center were selected. Additional wells were needed when the number of wells was less than five. The search radius for additional wells was increased systematically to a maximum distance of 101 cells (a 100-km [62.1-mi] 
radius; figs. 2 and 3 ) from the original cell or to the radius at which the target number of wells in the same hydrogeologic setting was obtained. The expanding-radius, moving-median grid-interpolation technique was similar to methods used in the glacial-aquifer hydrogeologic framework mapping project (Yager and others, 2018). If five wells were not available within a 100-km (62.1-mi) radius within the hydrogeologic setting, then the cell was assigned the median value of the entire hydrogeologic setting.

Grids were first calculated on the basis of available data for the actual top depth, bottom depth, and length of the open interval. A second version of the grids was created by merging actual data with estimated values for top depth and length of the open interval. Then, hybrid grids were created by merging data from the two versions, according to the following rules: Values based entirely on actual open interval data were given priority and were exclusively used when the well density was higher than five wells in a 10-km (6.21-mi) radius. Estimated values were combined with actual values to create hybrid grids when the search radius to find five wells with actual data on the top depth of the open interval was $10 \mathrm{~km}(6.21 \mathrm{mi})$ more than the search radius to find five wells with either an actual or estimated top depth of the open interval.
For some hydrogeologic settings, no public-supply well data were available. If a hydrogeologic setting contained data for fewer than 10 wells, then the data for the wells in that hydrogeologic setting were combined with those in another hydrogeologic setting to create typical-well open interval grids. In these cases, the CDF comparison steps were used to determine which neighboring hydrogeologic setting well construction data were suitable to include.

A variable smoothing algorithm was applied to the open interval grids to account for uncertainty in well locations, hydrogeologic setting boundaries, and areas with low data density. Smoothing minimized steep gradients in the open interval depth and thickness grids that occur across hydrogeologic setting boundaries. The smoothing was adjusted by a smoothing factor based on well spatial density. The smoothing factor is calculated dividing the distance to reach the five nearest wells by 10 and then adding plus 1 . For example, if the distance to reach five wells is $40 \mathrm{~km}(24.9 \mathrm{mi})$, then each cell was assigned the value obtained by averaging across two cells in each direction, or a 5 -square-kilometer $\left(\mathrm{km}^{2} ; 1.92\right.$-squaremile $\left[\mathrm{mi}^{2}\right]$ grid of $1-\mathrm{km}^{2}\left(0.38-\mathrm{mi}^{2}\right)$ cells. This procedure helps to minimize local anomalies while maintaining the overall structure of the data. 
A. Domestic-supply wells

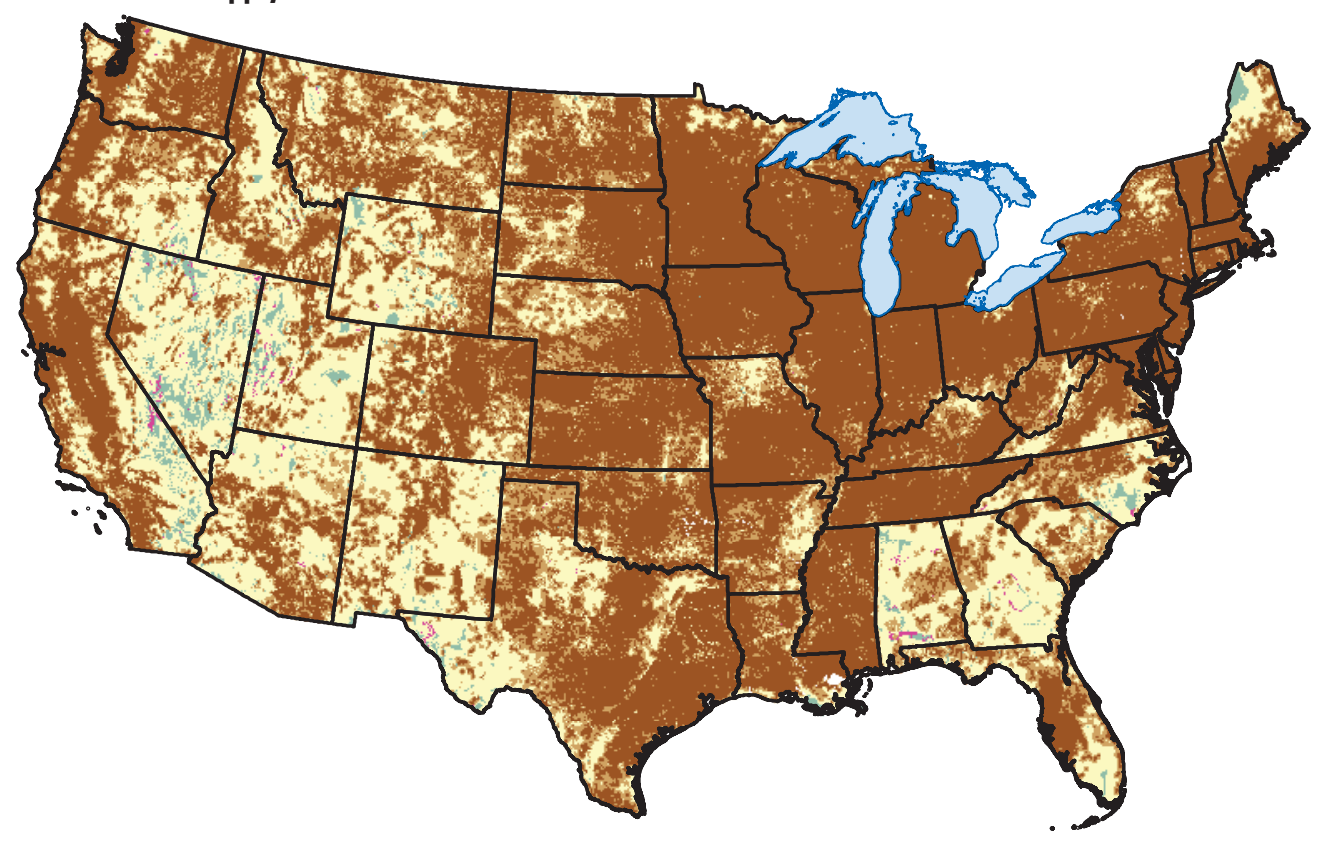

EXPLANATION

Distance to encounter five wells, in kilometers 0 to 5

More than 5 to 10

More than 10 to 50

More than 50 to 100

More than 100

\section{B. Public-supply wells}

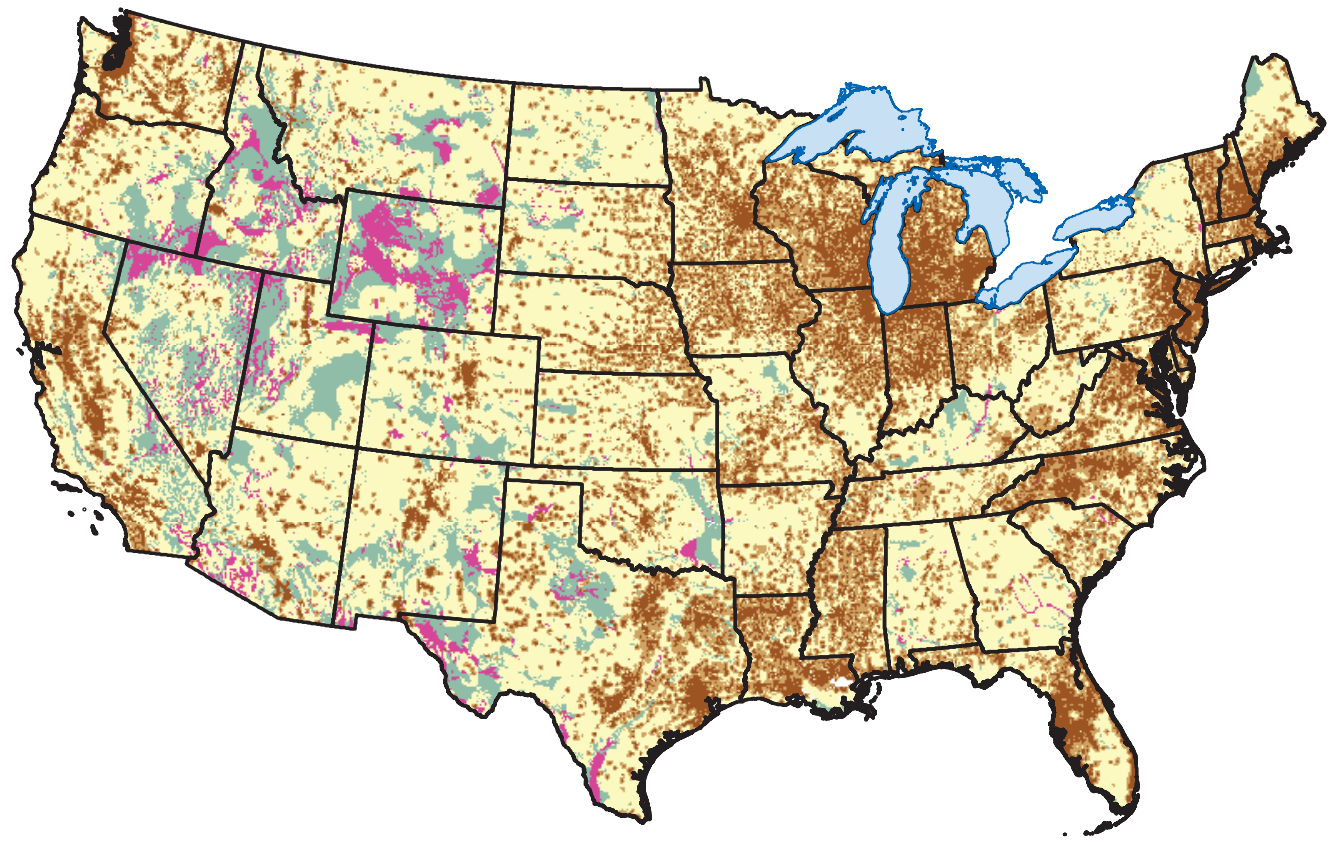

Figure 2. Maps showing the distance from a cell within a grid required to reach five wells with sufficient information to compute a median value for the bottom of the open interval for $A$, domestic-supply wells and $B$, public-supply wells in the conterminous United States. Grids presented here are also accessible in an interactive searchable map at https://doi.org/10.3133/sir20215069. 
A. Domestic-supply wells

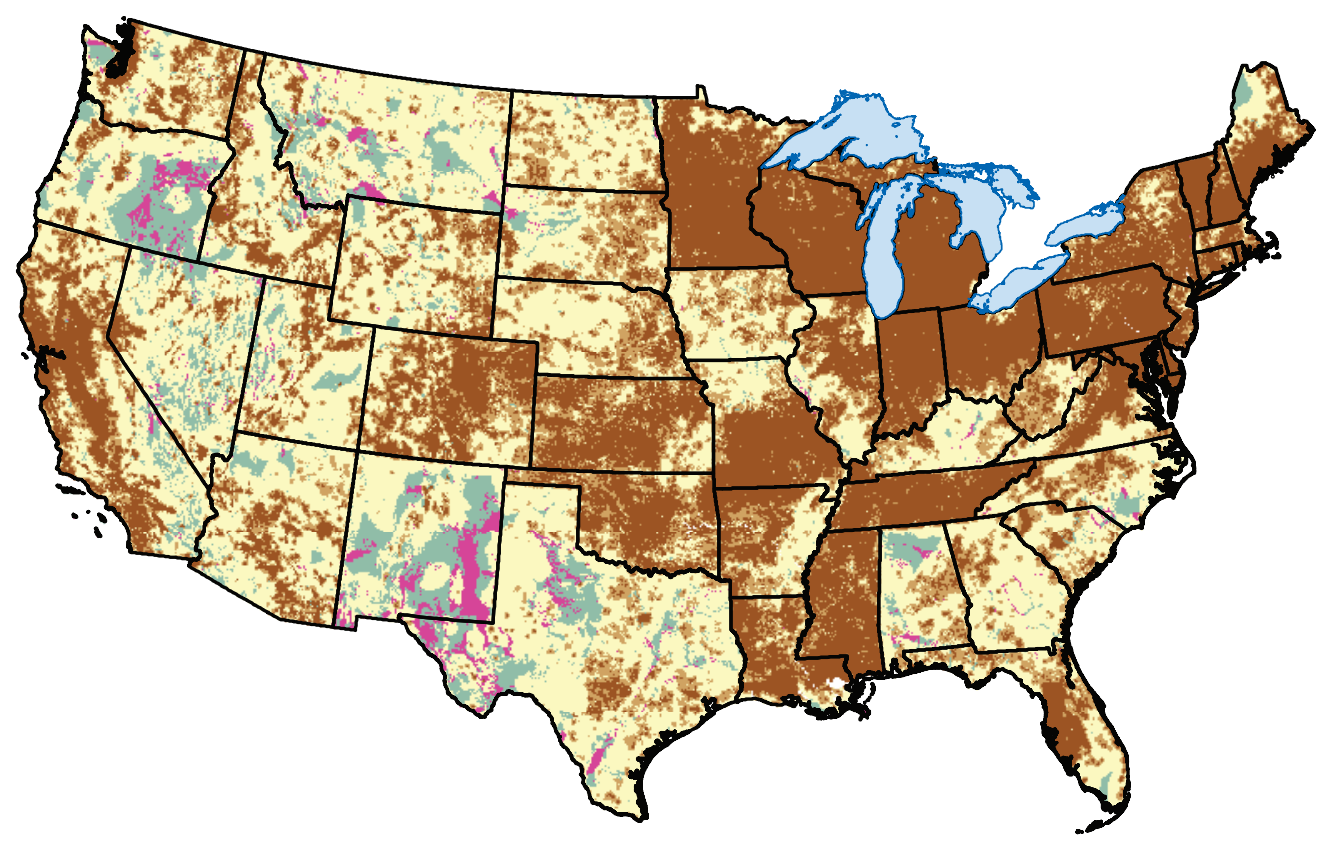

EXPLANATION

Distance to encounter five wells, in kilometers

0 to 5

More than 5 to 10

More than 10 to 50

More than 50 to 100

More than 100

\section{B. Public-supply wells}

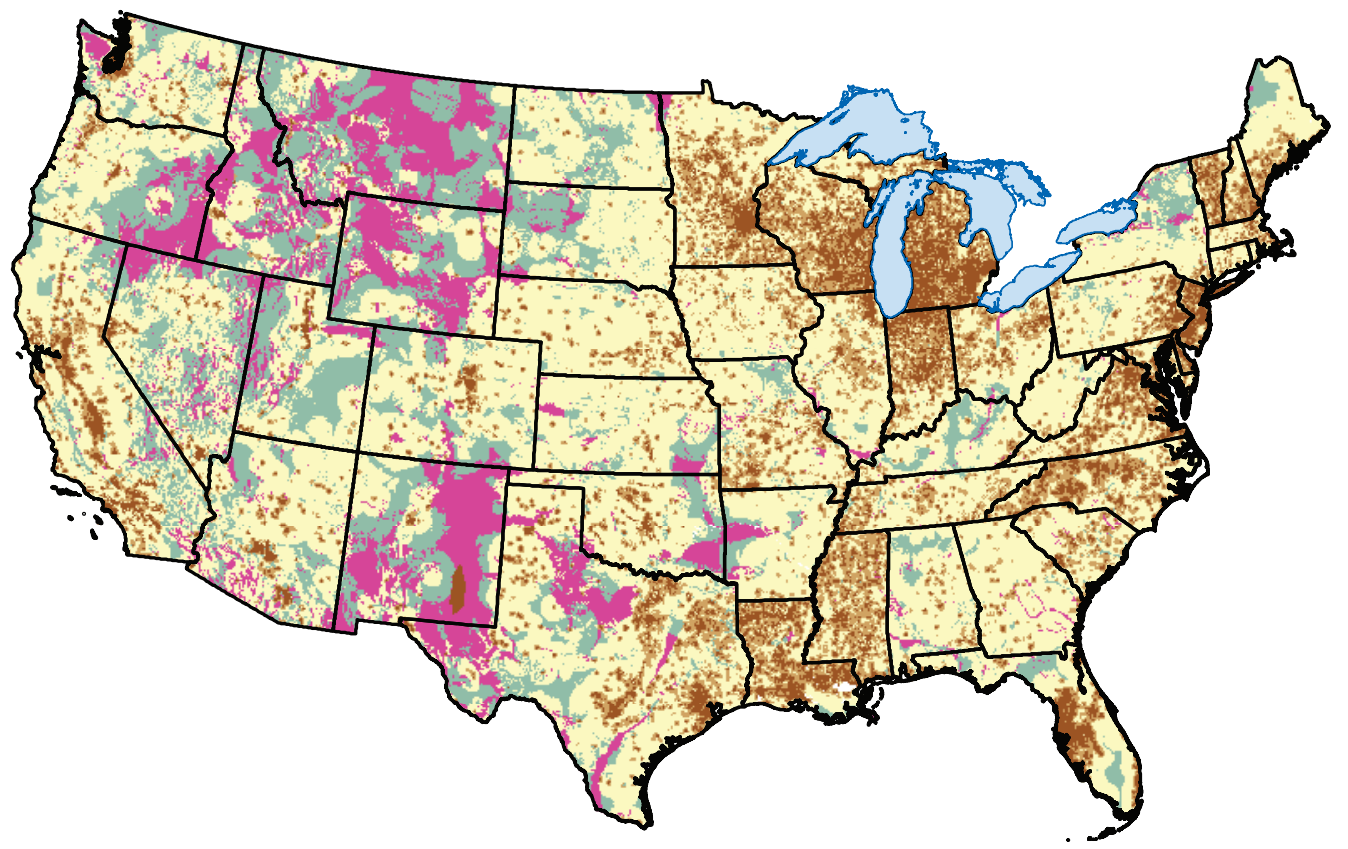

Figure 3. Maps showing the distance from a cell within a grid required to reach five wells with sufficient information to compute a median value for the open interval length for $A$, domestic-supply wells and $B$, public-supply wells in the conterminous United States. Grids presented here are also accessible in an interactive searchable map at https://doi.org/10.3133/sir20215069. 


\section{Results of Analyses}

Hydrogeologic settings were used to provide a framework for processing the well data and to organize summaries of the data. Grids were generated to represent data density and surfaces of approximate common depth and length of open intervals in the wells from which water is withdrawn for domestic- and public-drinking-water supply (withdrawal zones) within the conterminous United States.

\section{Hydrogeologic Settings}

Geospatial datasets of principal aquifers, secondary hydrogeologic regions, and overlying sediments including glacial sediment, coarse glacial sediment, and stream valley alluvium (alluvium) were merged to create a hydrogeologic setting dataset for the entire United States (fig. 1.1A-I). Principal aquifer designations and boundaries in the current [2021] geospatial dataset include changes that have occurred since extents of the principal aquifers were published in the Groundwater Atlas of the United States (Miller, 1999). For example, in the eastern United States, the Piedmont and Blue Ridge crystalline-rock aquifers were added (fig. 1.1B). The Pacific Northwest basaltic-rock aquifers were generalized by combining the northern California volcanic-rock aquifers, Pliocene and younger basaltic-rock aquifers, Miocene basalticrock aquifers, and volcanic and sedimentary-rock aquifers into one. The Pacific Northwest basin-fill aquifers were divided into separate Columbia Plateau basin-fill, Snake River basinfill, and Pacific Northwest basin-fill aquifers. The PugetWillamette Lowland aquifer system was also divided into the Puget Sound aquifer system (fig. $4 A$ ) and the Willamette lowland basin-fill aquifer.

The secondary hydrogeologic regions originally included three small areas with an "x" prefix (Belitz and others, 2019b) that were interpreted to be areas that likely should have been grouped with the corresponding principal aquifer. For this work, these areas were combined with the principal aquifers. The secondary hydrogeologic regions combined with principal aquifers were "xPuget Sound," "xColorado Plateau," and "xValley and Ridge" (fig. 4). Fifty-seven principal aquifers and 65 secondary hydrogeologic regions were intersected with glacial sediment, coarse glacial sediment, and alluvium overlying sediment data (fig. 5) to generate 288 distinct hydrogeologic setting areas (fig. 1.1A-I; table 2). Secondary hydrogeologic regions had more area with overlying sediment, including glacial sediment and coarse glacial sediment, but principal aquifers had more overlying alluvium (fig. $6 \mathrm{~A}$ and $B$ ).

Principal aquifers cover about 20 percent more area of the United States than secondary hydrogeologic regions (table 2), but the same number of hydrogeologic settings (144) have been designated in each type of setting. Sandstone and unconsolidated deposits of sand and gravel make up the largest principal aquifer areas (15.1 and 18.7 percent, respectively), and sedimentary lithologies make up the largest area of secondary hydrogeologic regions (25.5 percent). Hydrogeologic settings with overlying sediment accounted for a large portion but less than half the total hydrogeologic setting areas.

\section{Sources and Density of Well Data}

Across the Nation, the sources and density of wells for which construction records show either depth or open interval data or both vary widely. National, regional, and State datasets, including NWIS, were useful for filling in gaps in States with little or no publicly available well data (table 1). Few data were available in several hydrogeologic settings, and in some hydrogeologic settings, no data were available for public-supply wells. Maps showing the density of well depth and open interval data (in terms of distance to nearest five wells with available data) illustrate the spatial variability of those data (figs. 2 and 3). Records for depth and open interval in domestic-supply wells outnumber those for public-supply wells by more than 17 to 1 . About half the compiled well records for each well use have open interval information (table 1). Individual State datasets provided more data than all other sources combined.

The total number of well records (duplicates removed) from the five data sources with depth information was $5,737,122$ for domestic-supply wells and 320,490 for publicsupply wells (table 1). The average density of wells overall was 1.9 wells per square mile for domestic-supply wells and 0.11 well per square mile for public-supply wells (table 3 ), though the spatial distribution of the wells was variable.

Records for about 3.5 million domestic-supply wells and 174,000 public-supply wells included data sufficient to determine the length of open intervals (table 3 ). Because fewer well records were available with open interval length data compared with data for depth, the average density in the number of wells with open interval length data decreased to 1.2 wells per square mile for domestic-supply wells and 0.06 well per square mile per square mile for public-supply wells (table 3 ).

Large areas for which very few well data were available were identified throughout the country. Most of these areas coincide with regions of low population, but in some areas, any existing data were not publicly available or accessible. In the eastern United States, large swaths of mostly uninhabited forest in northwestern Maine, for example, had a very low well density (figs. $2 A$ and $B$ ). Well density, or at least available data for wells, was also very low in southern Florida, western Alabama, and southeastern North Carolina (more than 50- to $100 \mathrm{~km}$ [31.1 to $62.1 \mathrm{mi}$ ] to encounter five domestic-supply wells). In the West, western Texas, southern and northeastern New Mexico, northwestern and southwestern Arizona, southeastern California, eastern Oregon, and most of Nevada and Utah had low well densities compared with other regions (figs. $2 A$ and $B$ ). Overall, spatial patterns in actual domesticsupply well density closely matched those indicated with estimates of domestic-supply well density available from a previous study by Johnson and others (2019). 


\section{A. Puget Sound}

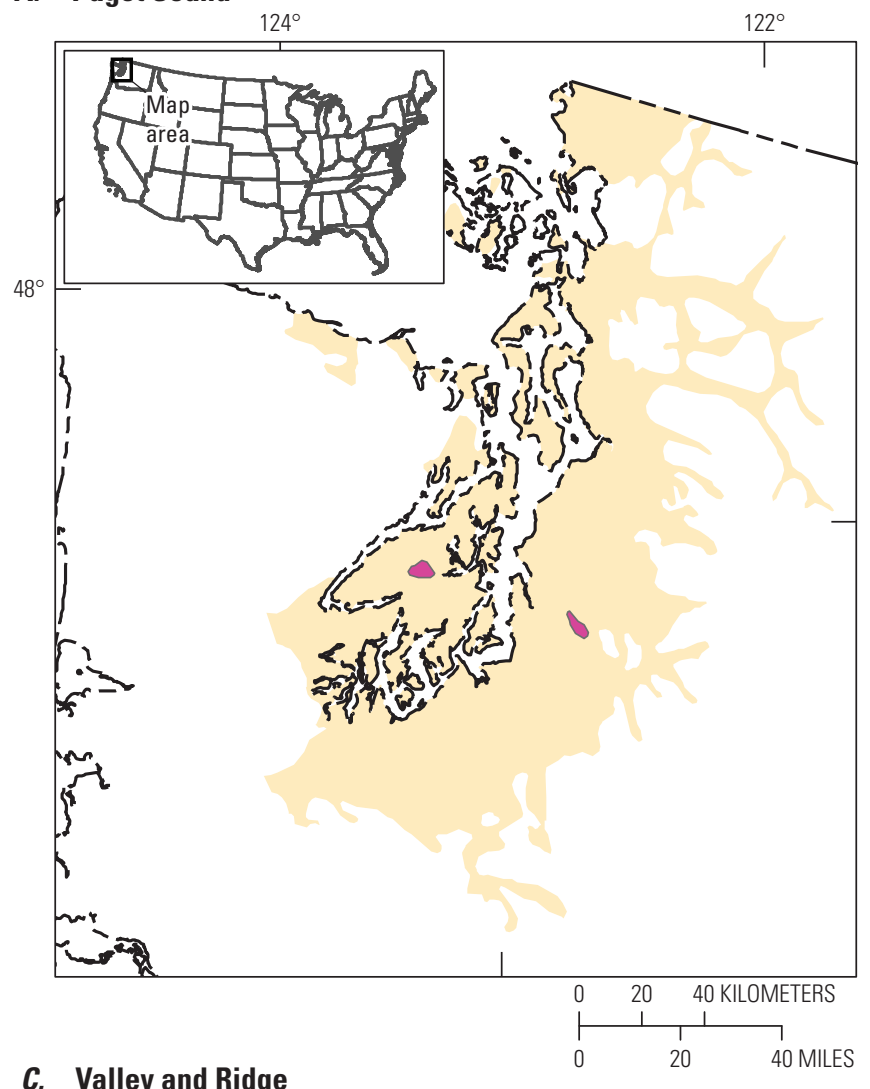

C. Valley and Ridge

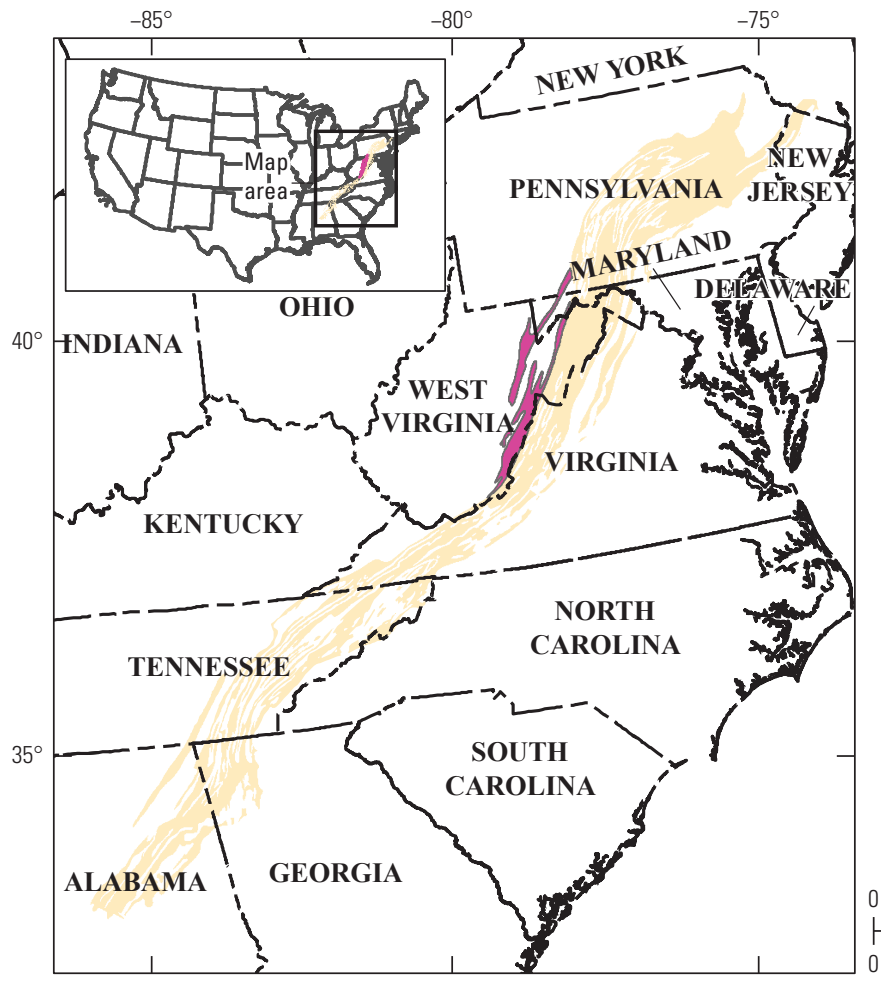

\section{B. Colorado Plateau}

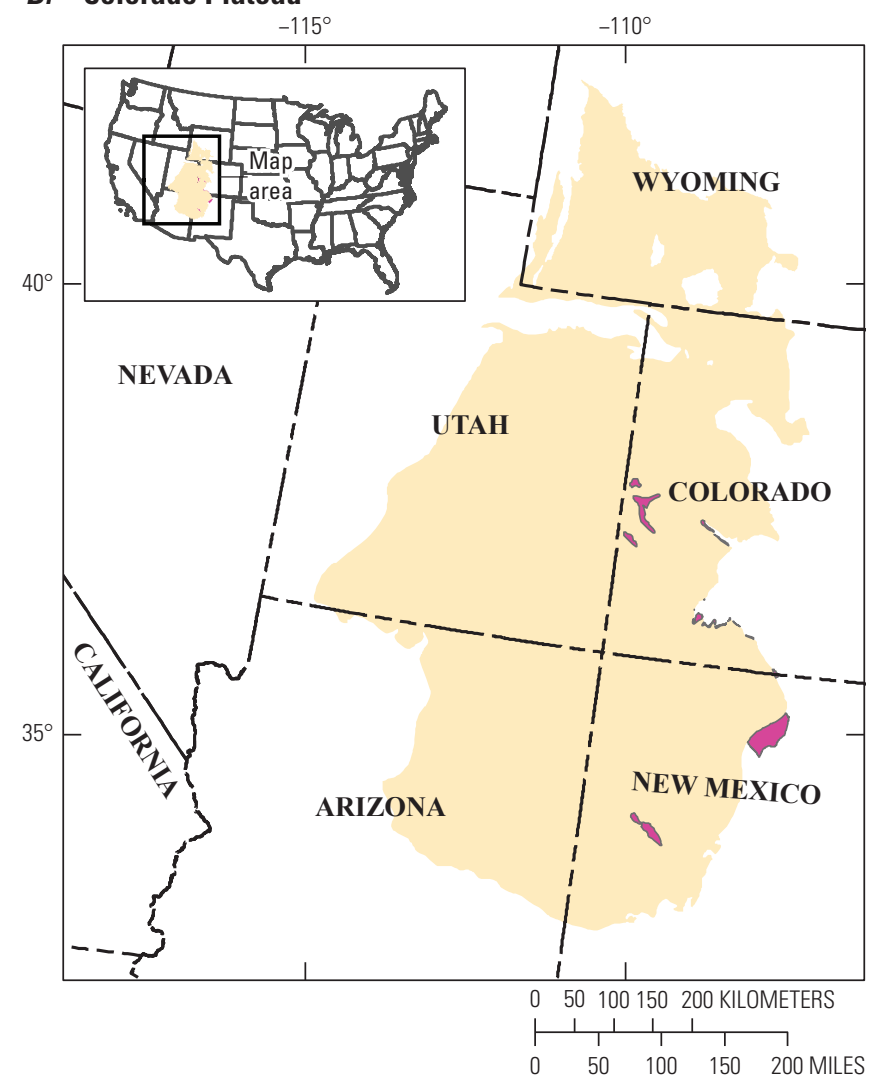

\section{EXPLANATION}

Principal aquifer

"x" secondary hydrogeologic region to combine

State boundary

0 50100150200 KILOMETERS

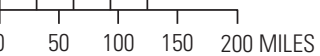

Base modified from U.S. Geological Survey, scale 1:1,000,000

Figure 4. Maps showing examples of secondary hydrogeologic regions that were combined with principal aquifers in the $A$, Puget Sound, $B$, Colorado Plateau, and $C$, Valley and Ridge principal aquifers. 


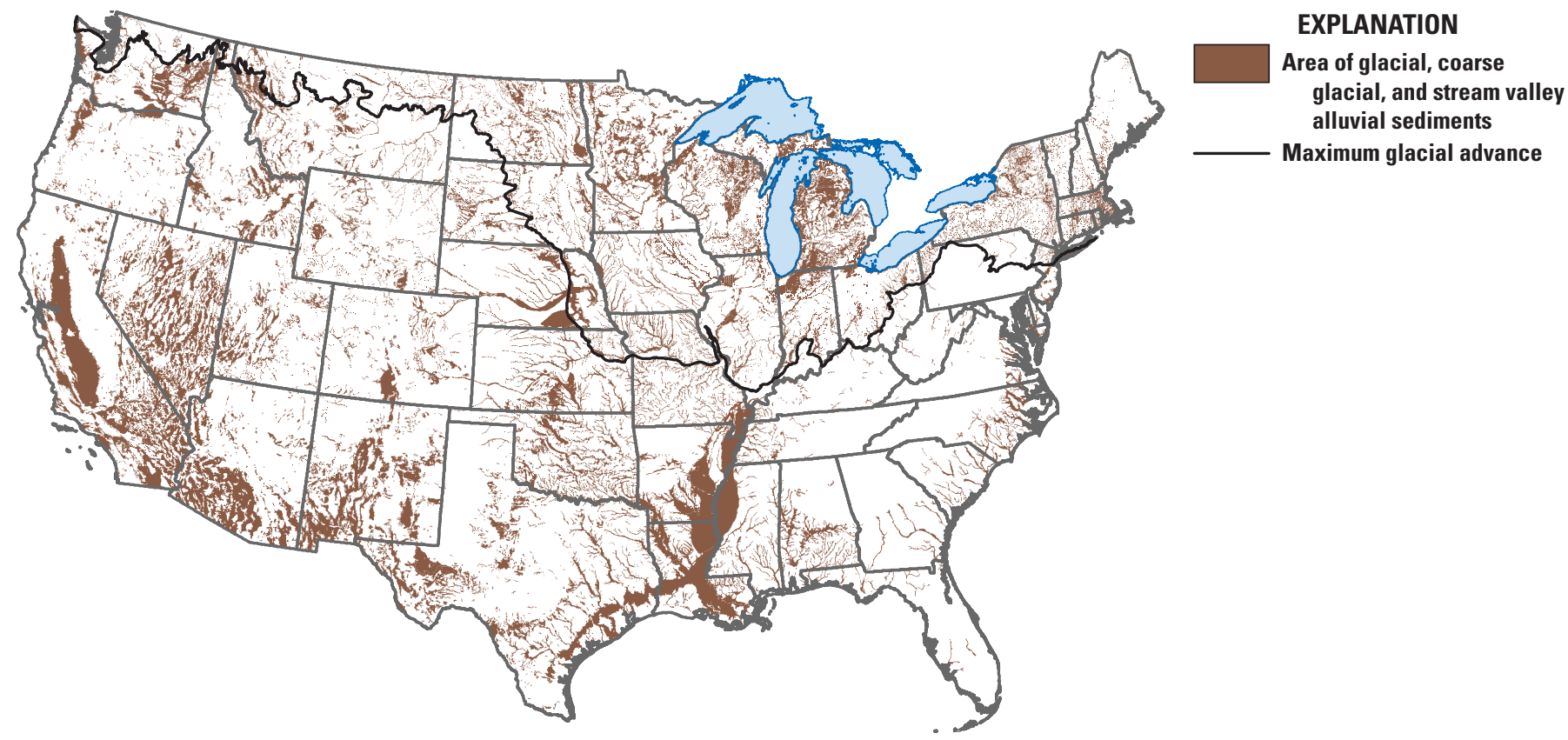

Figure 5. Map showing the locations of glacial, coarse glacial, and stream valley alluvial sediments in the conterminous United States.

Open interval data in general were not as widely available as depth data, and in some instances, records contained almost no data on open intervals. Records for domestic-supply in Oregon, Montana, New Mexico, and Texas included far less data on open intervals than records for domestic-supply wells in other parts of the conterminous United States (fig. $3 A$ ). Records for public-supply wells also had less open interval data in southeastern Oregon, Montana, Wyoming, New Mexico, western Arkansas, eastern Kansas, and northern New York than did records for domestic-supply wells in other parts of the conterminous United States (fig. 3B).

Records for several hydrogeologic settings had few domestic-supply-well data, and several other settings had no public-supply well data available. Hydrogeologic settings without public-supply well data include the ArbuckleSimpson (with alluvium), Texas-Triassic, Front Range, Texas Cretaceous, Northern Rocky Mountains-S, and Blue Mountains areas (fig. 1.1C, $G$, and $I$ ). Parts of these aquifers without overlying sediments had public-supply well data, however, which were used to estimate public-supply open interval grids in areas with overlying sediments where data were not available, as described in the "Open Interval Depths and Lengths" section of this report. Data for fewer than 10 public-supply wells were available for several hydrogeologic settings. These include Cape Cod and islands-glacial, Roswell Basin aquifer system, Blue Mountains, and Ozarks Paleozoic and $-\mathrm{X}$ (with and without alluvium), Washington-Oregon coast ranges $\mathrm{S}$ and $\mathrm{V}$, Ada-Vamoosa aquifer, Middle Rocky Mountains-X, Florida-T, north-central interior-PZ glacial, upper Tertiary aquifers, Texas-Pennsylvanian, Ordovician aquifers, Ouachita Mountains, north-central interior-PZ, and Northern Cascade Mountains hydrogeologic settings with alluvium (fig. 1.1A-I; Kauffman and others, 2021). In some hydrogeologic settings with small numbers of wells, wells were combined with those of similar hydrogeologic settings to calculate hydrogeologic setting median open interval depths and lengths. In other cases, where similar hydrogeologic settings were not available, as few as two wells were used to generate a median for a hydrogeologic setting.

Well data density was related with the presence of overlying sediment. More wells are in areas with overlying sediment even though most of the country does not have overlying sediment (fig. 6). In secondary hydrogeologic regions, the proportion of domestic-supply wells by overlying sediment type were similar to proportions of public-supply wells by sediment type, indicating both types of wells were installed in similar settings. Distributions of all wells by sediment type in principal aquifers were different from their distributions in secondary hydrogeologic regions (fig. $6 A$ and $B$ ), but the distribution of domestic- and public-supply wells by sediment type within secondary hydrogeologic regions (fig. $6 D$ and $F$ ) or within principal aquifers (fig. $6 C$ and $E$ ) were similar. Principal aquifers have more domestic- and public-supply wells than secondary hydrogeologic regions, indicating that principal aquifers are more often used for a water supply than secondary hydrogeologic regions (table 3). Hydrogeologic settings with no overlying sediment have many more wells in principal aquifers than secondary hydrogeologic regions because the overlying sediment is often used as a water supply in secondary hydrogeologic regions (fig. $6 C-F$; tables 3 and 4 ). 


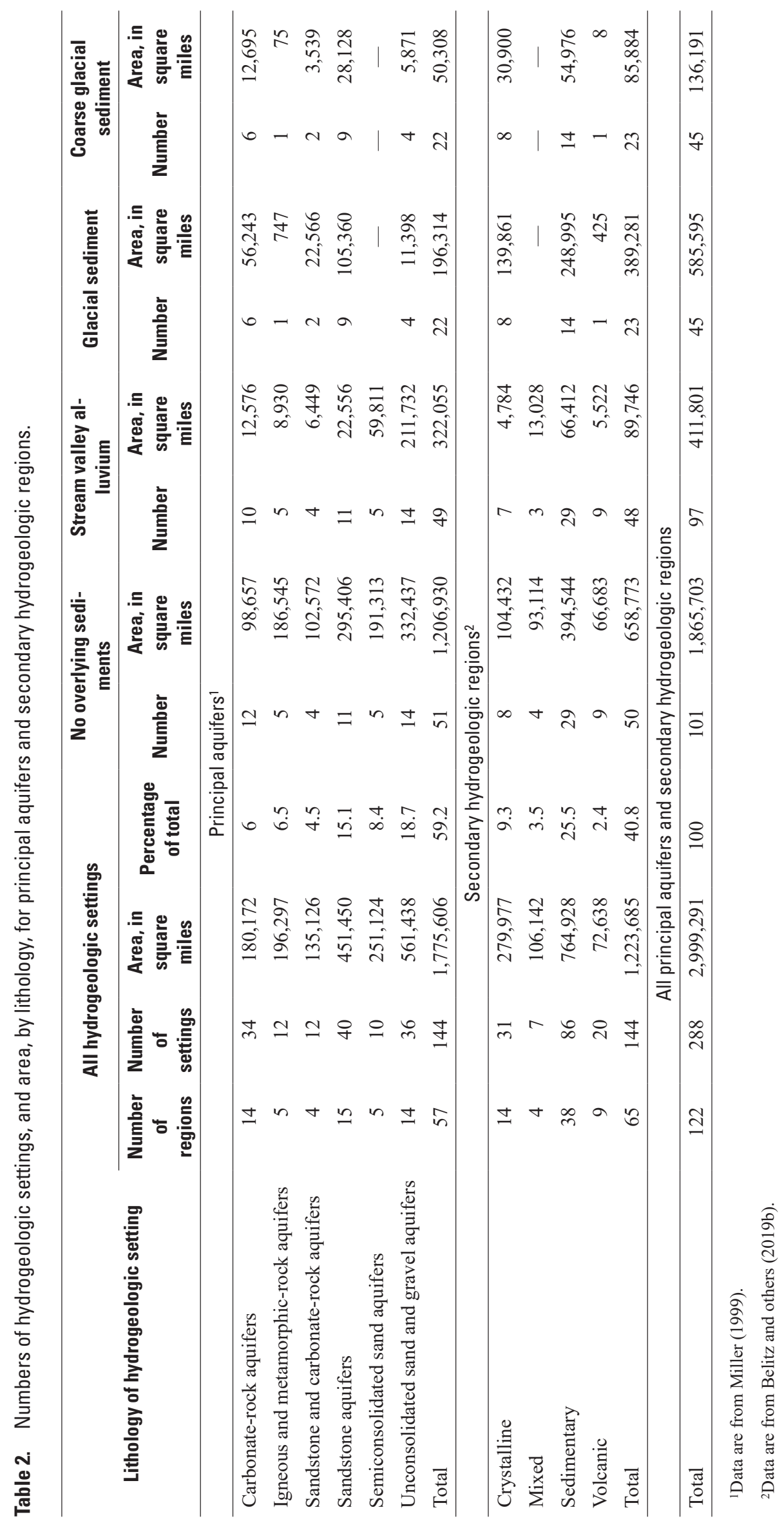


A. Secondary hydrogeologic region area with overlying sediment for all well uses

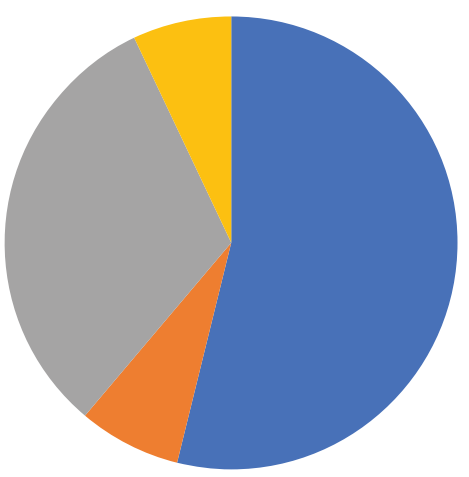

C. Domestic-supply wells in secondary hydrogeologic regions with overlying sediment

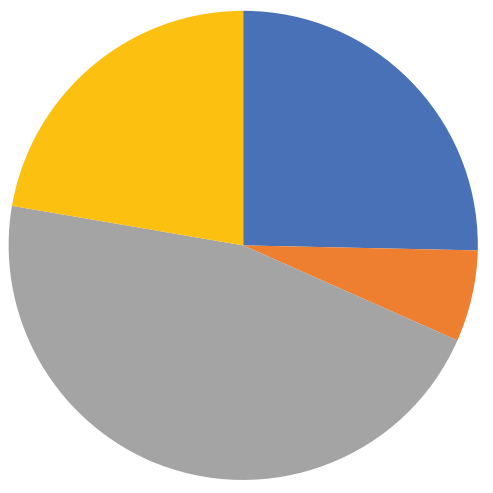

E. Public-supply wells in secondary hydrogeologic regions with overlying sediment

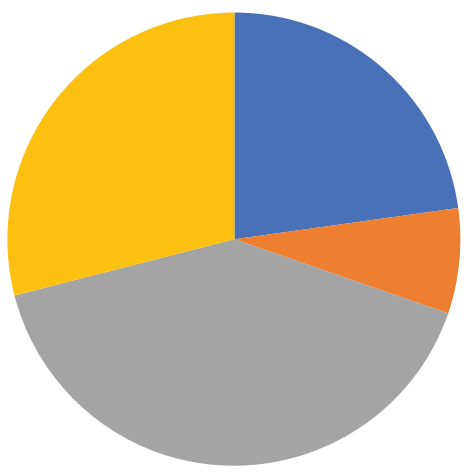

\section{EXPLANATION}

Overlying sediment

None

Stream valley alluvium

Glacial

- Coarse glacial
B. Principal aquifer area with overlying sediment for all well uses

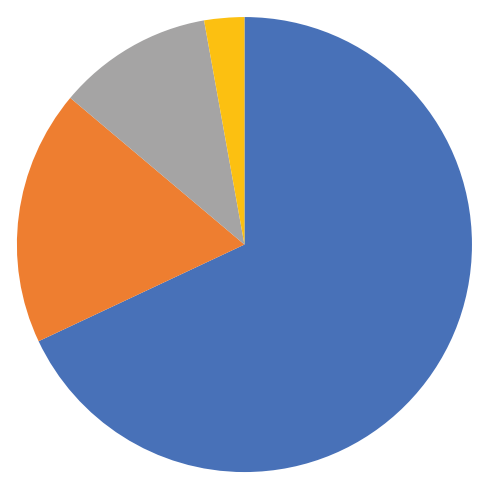

D. Domestic-supply wells in principal aquifer areas with overlying sediment

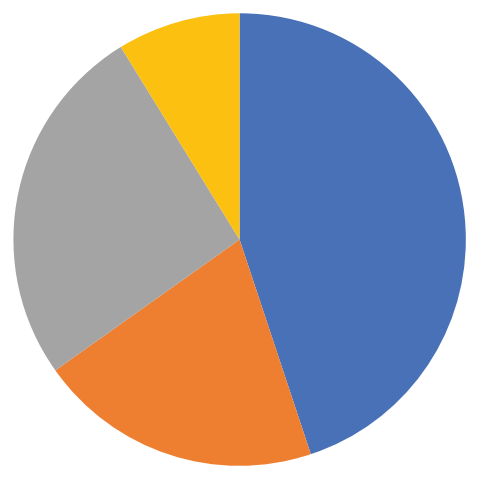

F. Public-supply wells in principal aquifer areas with overlying sediment

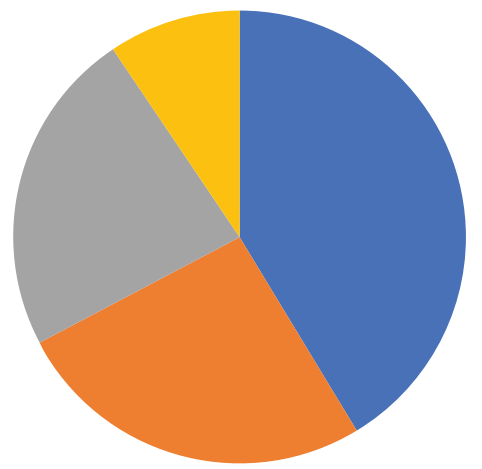

Figure 6. Pie charts showing the proportion of area with and without sediment overlying $A$, secondary hydrogeologic regions; $B$, principal aquifers; and proportion of wells in areas with and without overlying sediment for $C$, domestic-supply wells in hydrogeologic settings, $D$, domestic-supply wells in principal aquifers $E$, public-supply wells in secondary hydrogeologic regions, and $F$, public-supply wells in principal aquifers in the conterminous United States. 


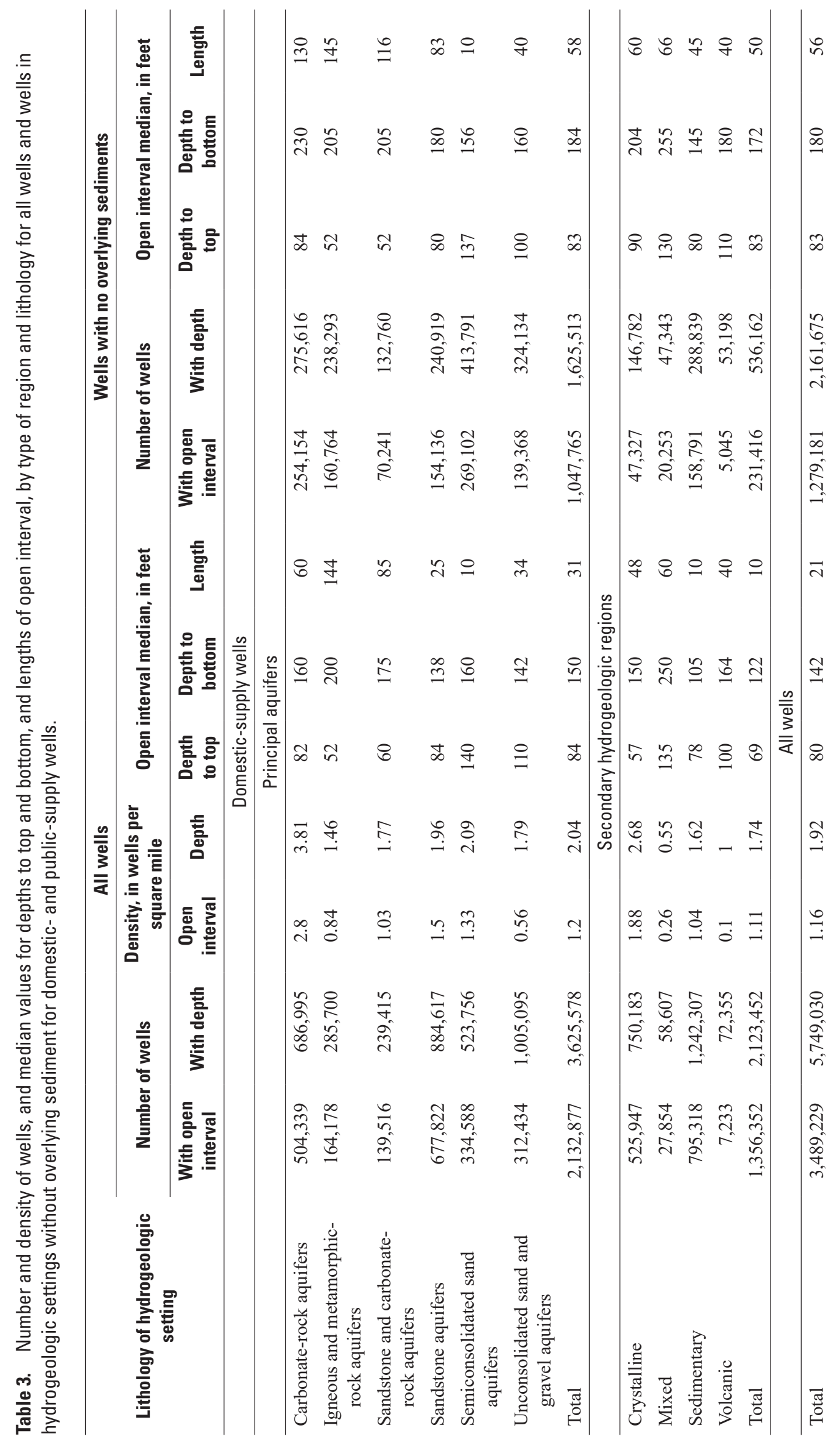




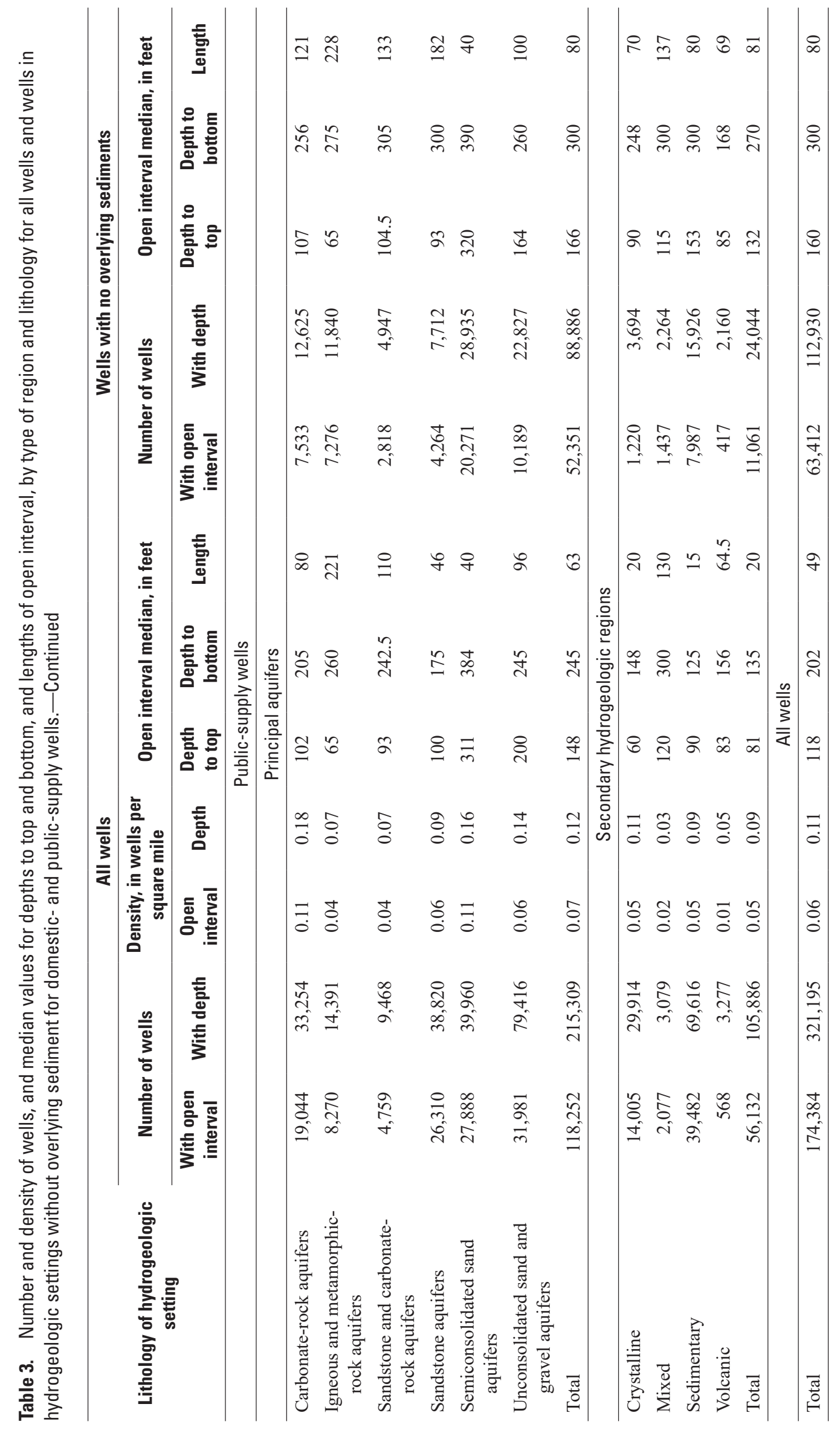




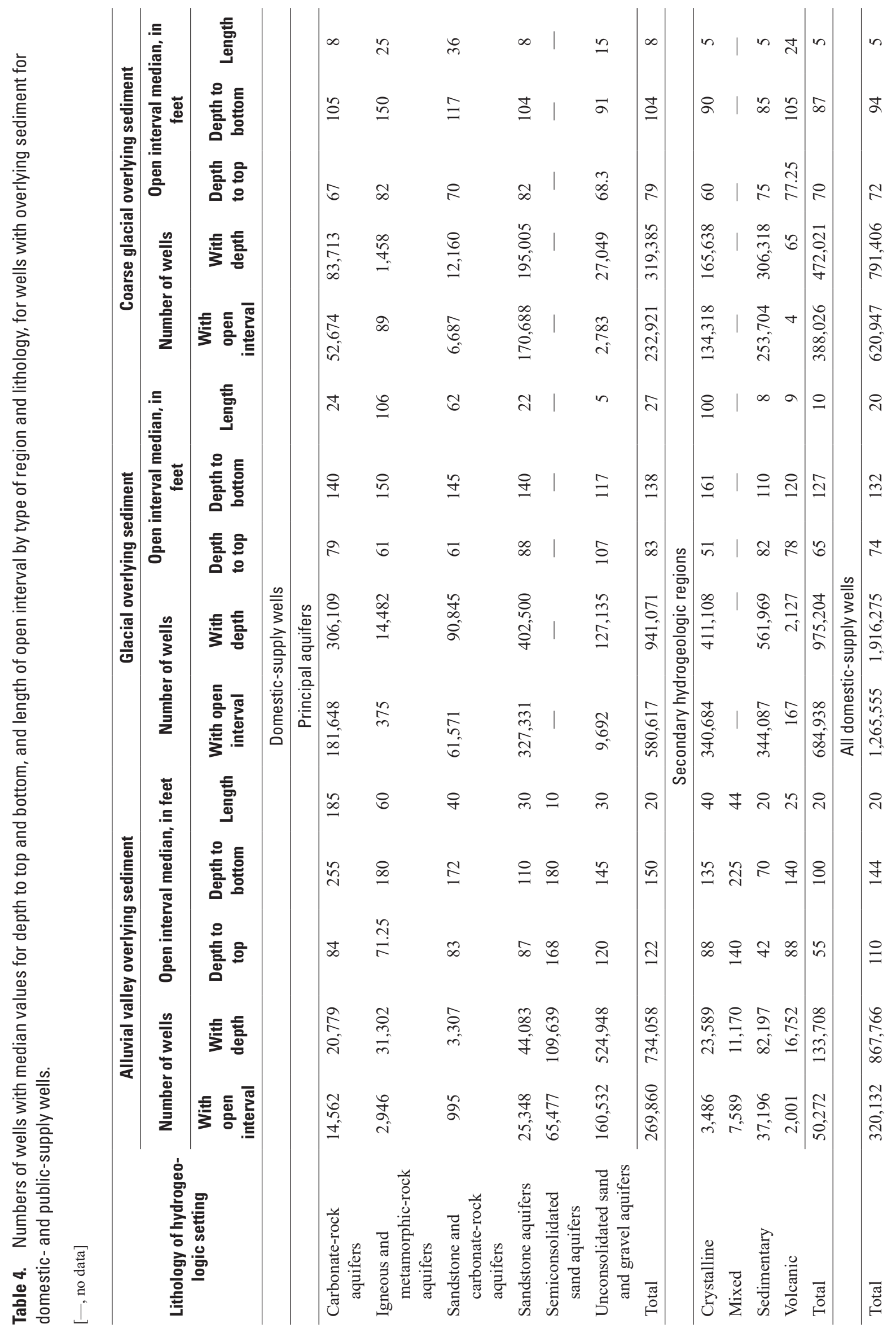




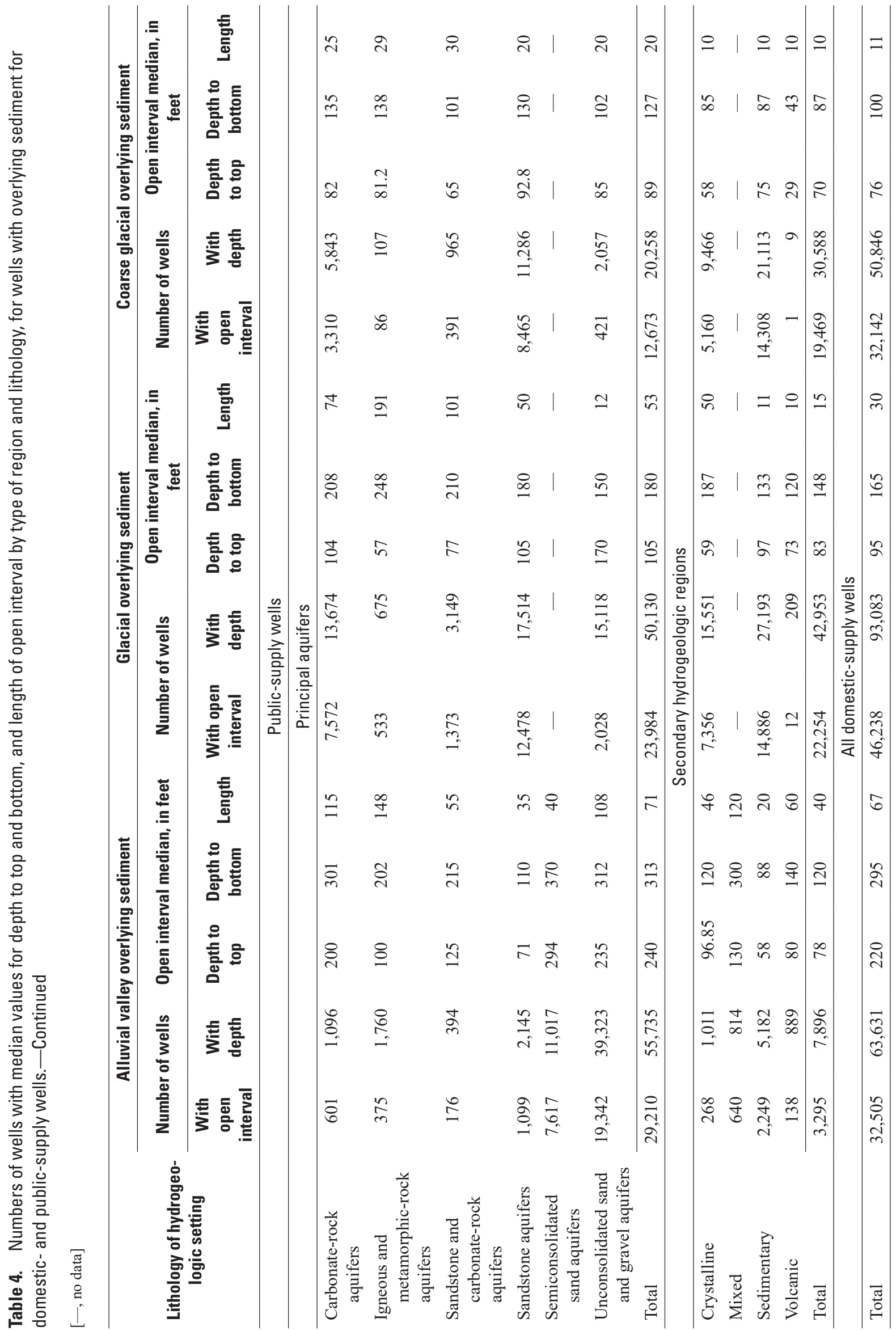




\section{Open Interval Depths and Lengths}

All 6.1 million wells for which data were included in this study had depth information, but 40 percent were missing open interval data (table 1). The median depths to the bottom of the open interval were $142 \mathrm{ft}(43.3 \mathrm{~m})$ for domesticsupply wells and $202 \mathrm{ft}(61.6 \mathrm{~m})$ for public-supply wells (table 3). The median open interval length was $21 \mathrm{ft}(6.4 \mathrm{~m})$ for domestic-supply wells and $49 \mathrm{ft}(14.9 \mathrm{~m})$ for public-supply wells (table 3). Most of the median depths (fig. 7) and open interval lengths (fig. 8) of supply wells in secondary hydrogeologic region areas were shallower and of shorter length than those in the principal aquifers; this pattern is more evident in the wells with overlying sediment. Overall and when grouped by rock type and overlying sediment type, the median length of the open interval in domestic-supply wells was generally shorter than that in public-supply wells for the same grouping, with a few exceptions such as for wells in crystalline rock aquifers with overlying glacial sediment (fig. 8; table 4). Open interval values had inconsistent or scattered relations with depth, but the patterns varied by hydrogeologic setting and were more consistent when examined by hydrogeologic settings. This made it possible to estimate open intervals in hydrogeologic settings where data were sparse (table 3). Open interval data were critical to the development of the top depth and length of the open interval grids.

Median well depths and lengths of open intervals in records for domestic- and public-supply wells varied with similar patterns by lithology of the hydrogeologic setting (fig. 1.1) and type of overlying sediment, but were different in a few discrete areas (figs. 9, 10, and 11; table 4). Overall, the median bottom depths of open intervals for public-supply wells in each major rock type in principal aquifers are deeper than those in domestic-supply wells (fig. $7 A$ and $B$; table 3 ). The median depths of domestic- and public-supply wells in crystalline and volcanic rock types in secondary hydrogeologic regions are similar; however, the public-supply well depth is slightly less (table 3). Also, the median open interval bottom depth for wells completed in areas with overlying glacial sediment were greater than those with overlying coarse glacial sediment (fig. 7; table 4). Looking at principal aquifer lithology, the median open interval bottom depth for wells completed in carbonate rock aquifers was greater if they had overlying stream valley alluvium, because well installers likely drilled through the alluvium and targeted these deeper, generally more highly productive formations (table 4).

Domestic-supply wells in hydrogeologic settings with overlying glacial sediment were deepest when completed in crystalline rocks. Domestic-supply wells completed in semiconsolidated sand had the shortest median open interval in hydrogeologic settings without overlying sediments. Domestic-supply wells completed in carbonate rocks had the longest median open intervals in hydrogeologic settings with overlying alluvium. Where coarse glacial sediment was present above sedimentary and crystalline rocks, median open interval lengths for domestic-supply wells were the shortest.
The median public-supply well open interval was shortest when wells were drilled in hydrogeologic settings with sedimentary lithology with overlying glacial sediment and coarse glacial sediment (table 4). Public-supply wells drilled in areas without overlying sediments had the shortest open intervals in hydrogeologic settings with semiconsolidated sand aquifers. The longest median lengths of open intervals in public-supply wells were for wells in igneous and metamorphic rocks, perhaps owing to their low porosity and few interconnected water-bearing fractures.

The data required to generate grids of the depth to the top and length of open intervals were not widely available. Records for more than half of the wells in some datasets used in this study, such as the domestic-supply well NGA dataset (table 1), were missing open interval data. When examining open interval bottom depth versus length, some hydrogeologic settings had narrow data distributions whereas others had large departures from the median. Some CDFs showed significant increases in open interval top depths where hydrogeologic settings had overlying sediment (tables 1.1 and 1.2; Kauffman and others, 2021). Some open interval fitting equations produced exaggerated estimates of open interval lengths. Most bedrock wells completed with open boreholes had a 1:1 slope of open interval bottom depth to open interval length with an offset that varied with the presence of overlying sediment (Kauffman and others, 2021). In general, the slope of that relation was lower in hydrogeologic settings with overlying stream valley alluvium. Wells completed in unconsolidated or semiconsolidated material commonly had bimodal (or multimodal) relations of depth to the bottom to length of open interval, and estimates of open interval length included multiple modes representing multiple withdrawal zones. For example, the Basin and Range basin-fill aquifer and the Basin and Range basin-fill aquifer with overlying alluvium have two slightly different bimodal relations of open interval length to open interval bottom depth for domestic-supply wells (fig. $12 \mathrm{~A}$ and $B$ ).

\section{Drinking Water Supply Open Interval Grids}

Grids representing the positions of open intervals of typical domestic- and public-supply wells were developed to support large regional or national scale water-resource and water-quality investigations. Three grids were created for both domestic- and public-supply wells: depth to top of open interval (fig. 13), depth to bottom of the open interval (fig. 14), and median length of open interval (fig. 15). In less populated States, such as Arizona and South Dakota, some large areas with minor variation in open interval depths and lengths are related to differences in data density, which are apparent in both well-use type maps.

The typical-well open interval grids vary by hydrogeologic setting. For example, domestic- and public-supply wells are deep in South Dakota because they must be drilled through low-permeability shales to reach the underlying productive 


\section{A. Median depth to the bottom of open interval in domestic-supply wells}

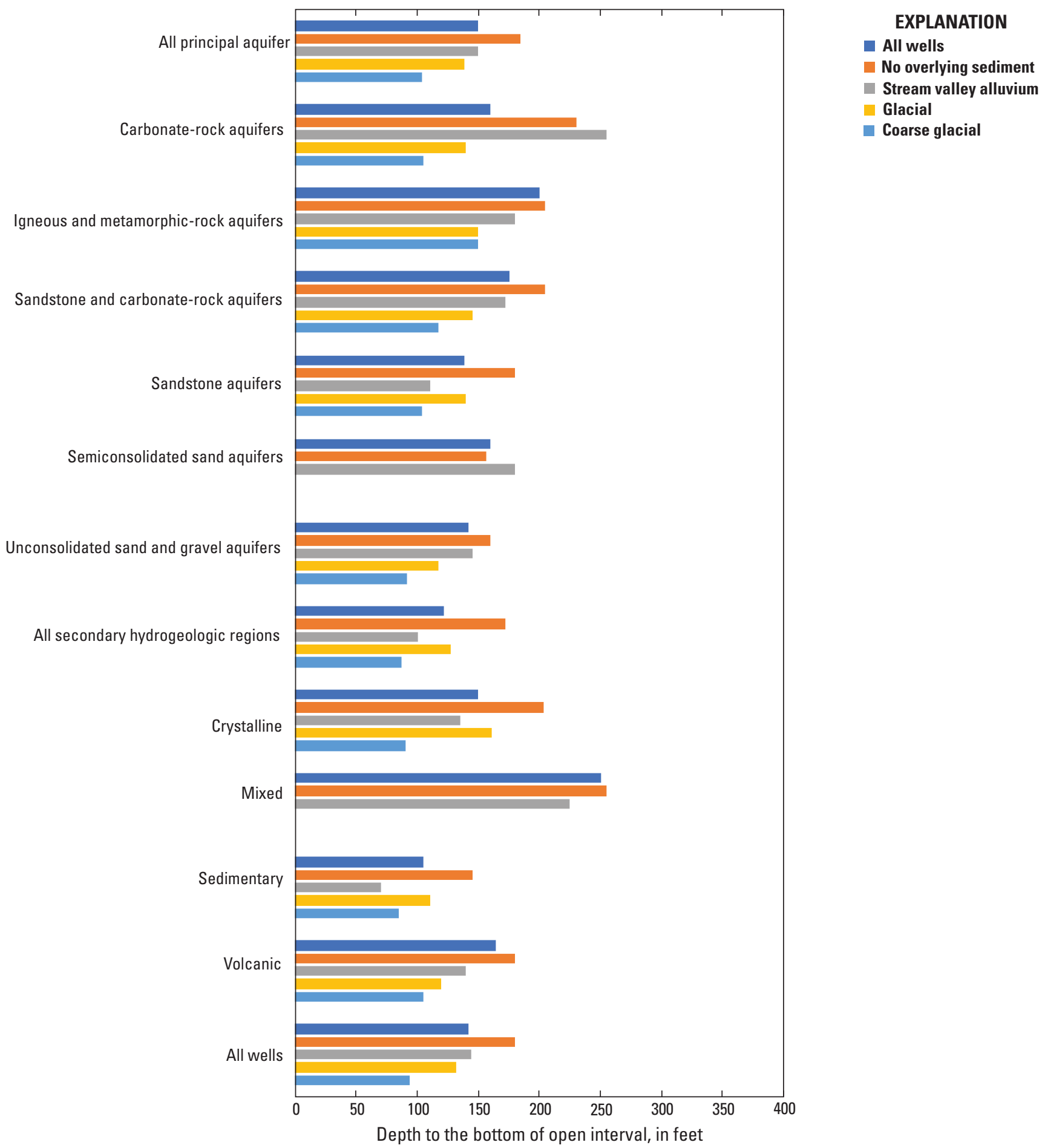

Figure 7. Bar graphs showing the median depth to the bottom of open interval in wells used for drinking water, by lithology and with and overlying sediment, for $A$, domestic- and $B$, public-supply wells in the conterminous United States. 
B. Median depth to the bottom of open interval in public-supply wells

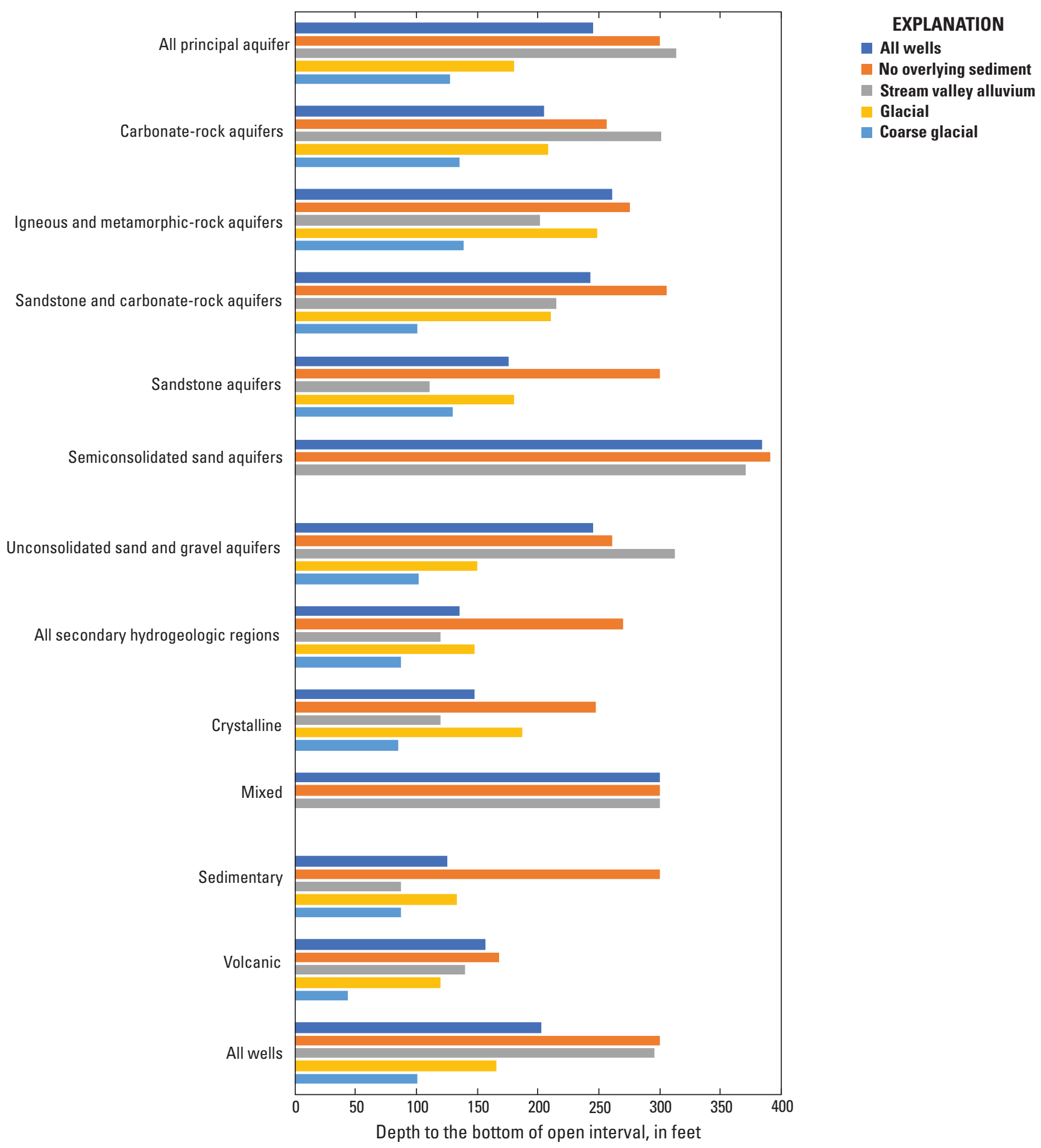

Figure 7.-Continued 
A. Median open interval length of domestic-supply wells

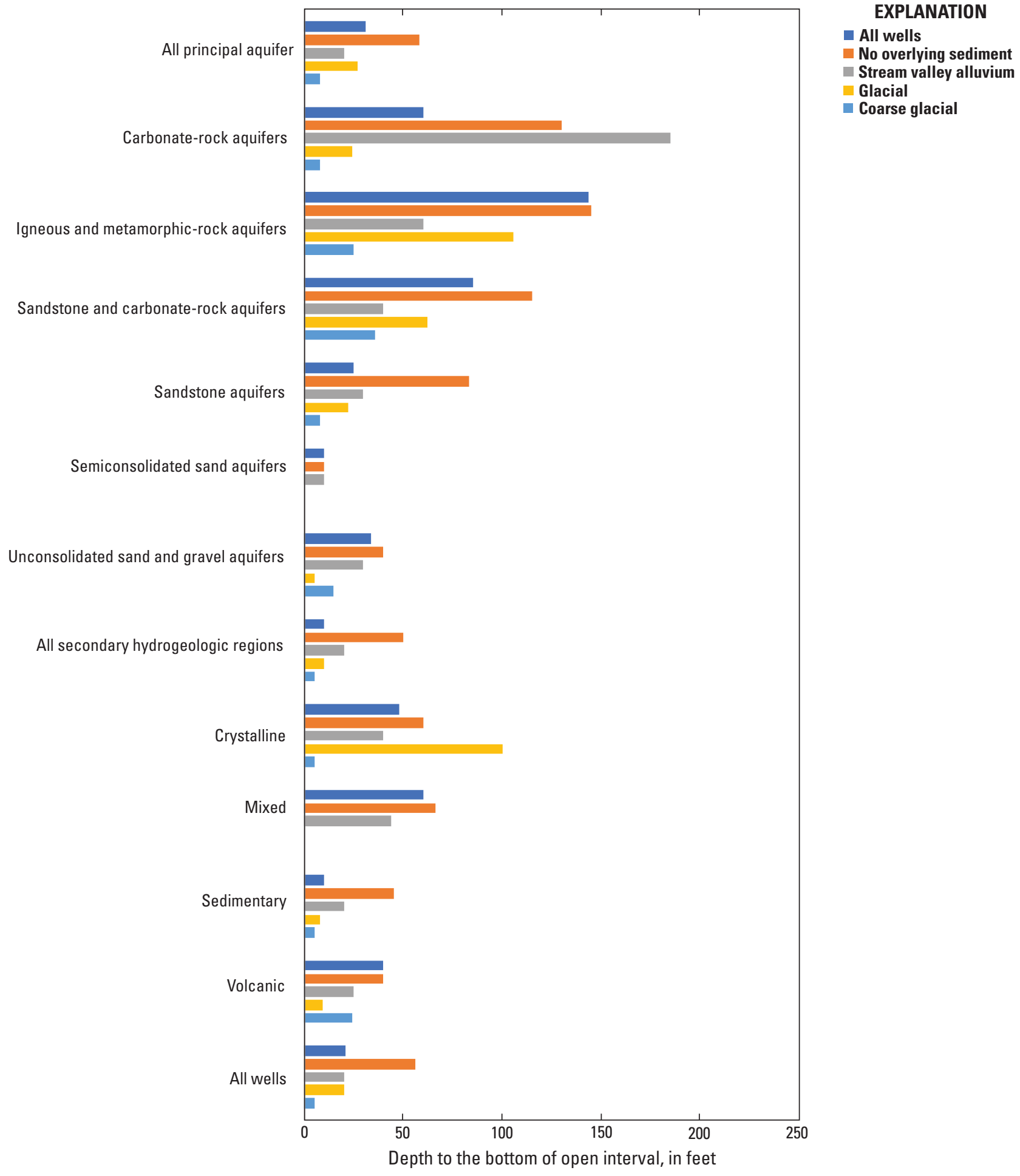

Figure 8. Bar graphs showing the median length of the open interval in wells used for drinking water, by lithology and overlying sediment, for $A$, domestic- and $B$, public-supply wells in the conterminous United States. 
A. Median open interval length of public-supply wells

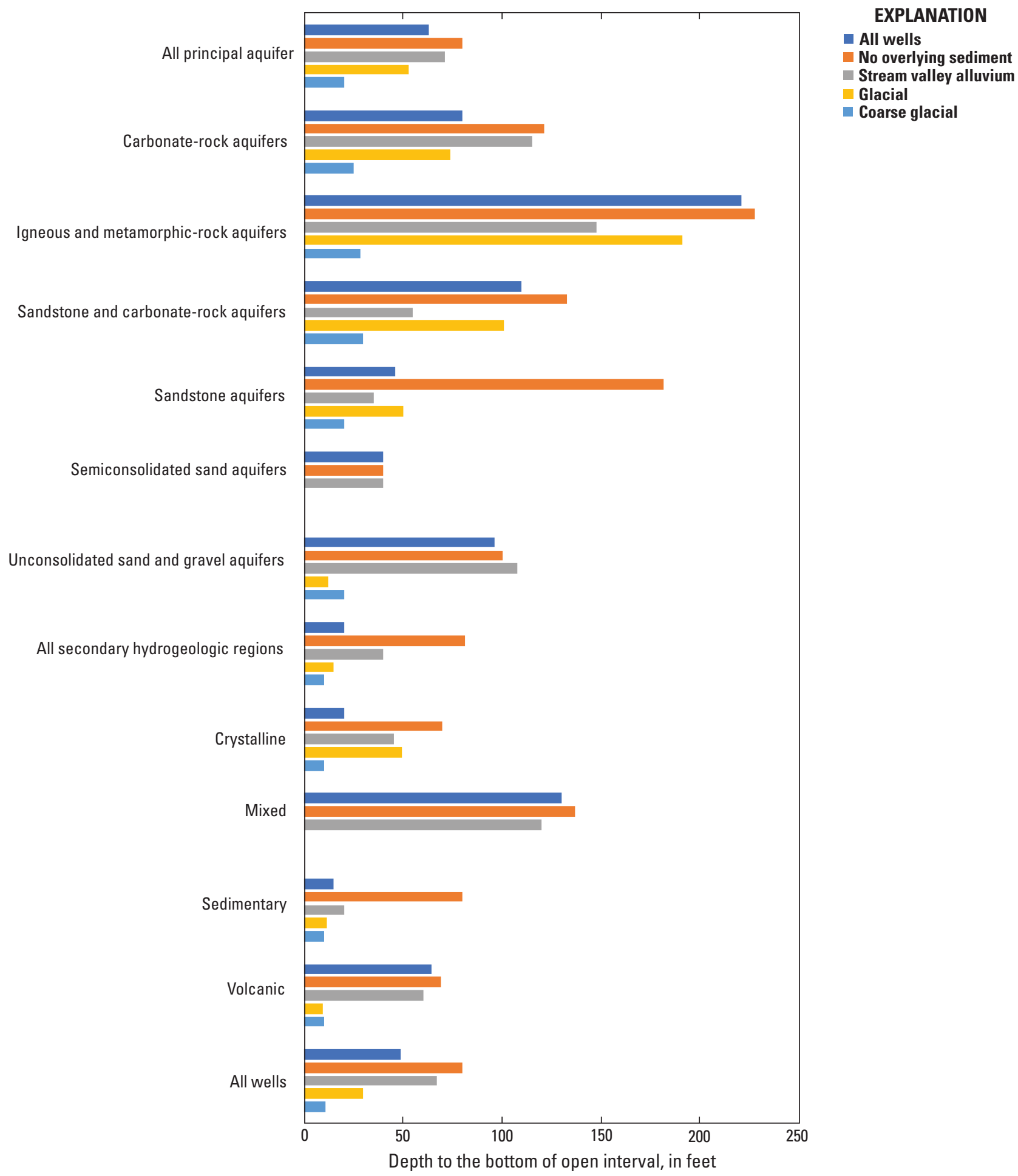

Figure 8.-Continued 
A. Domestic-supply wells

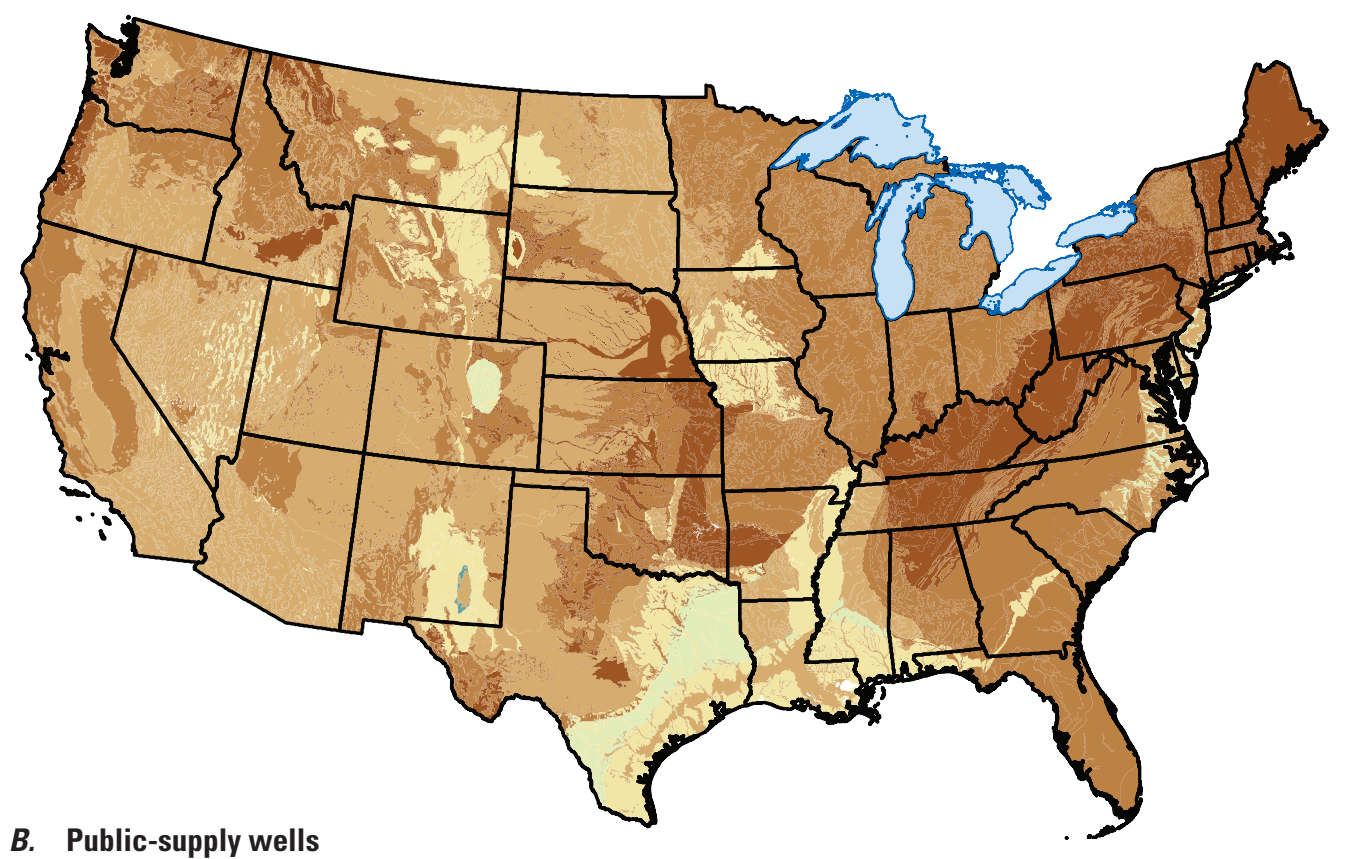

\section{EXPLANATION}

Median depth to the top of the open interval, in feet

Less than 50

More than 50 to 100

More than 100 to 150

More than 150 to 200

More than 200 to 300

More than 300 to 500

More than 500 to 1,000

More than 1,000 to 5,000

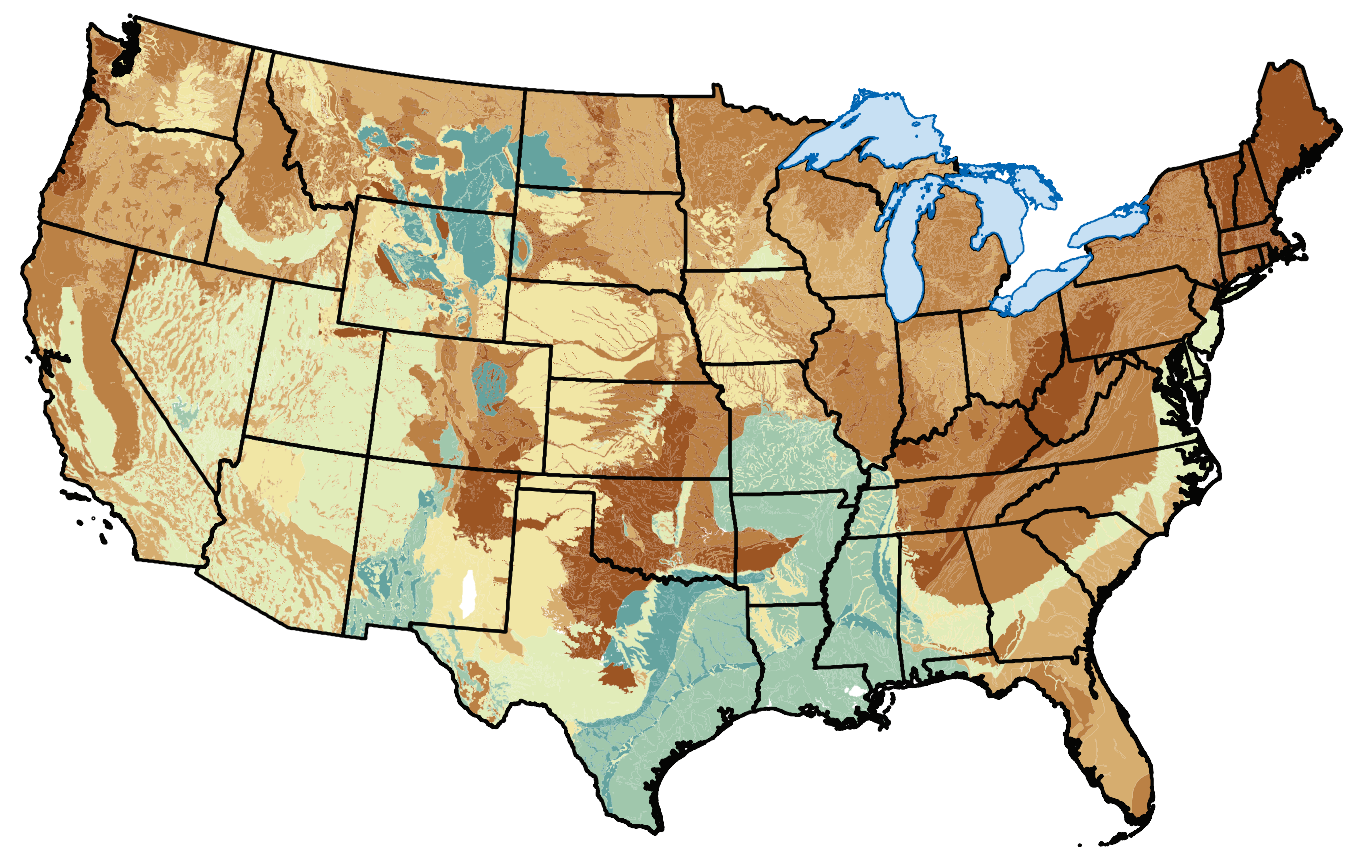

Figure 9. Maps showing the median depth to the top of the open interval of wells used for drinking water for each hydrogeologic setting by $A$, domestic- and $B$, public-supply wells in the conterminous United States. Hydrogeologic setting names and locations are identified in figure 1.1 of this report. 


\section{A. Domestic-supply wells}
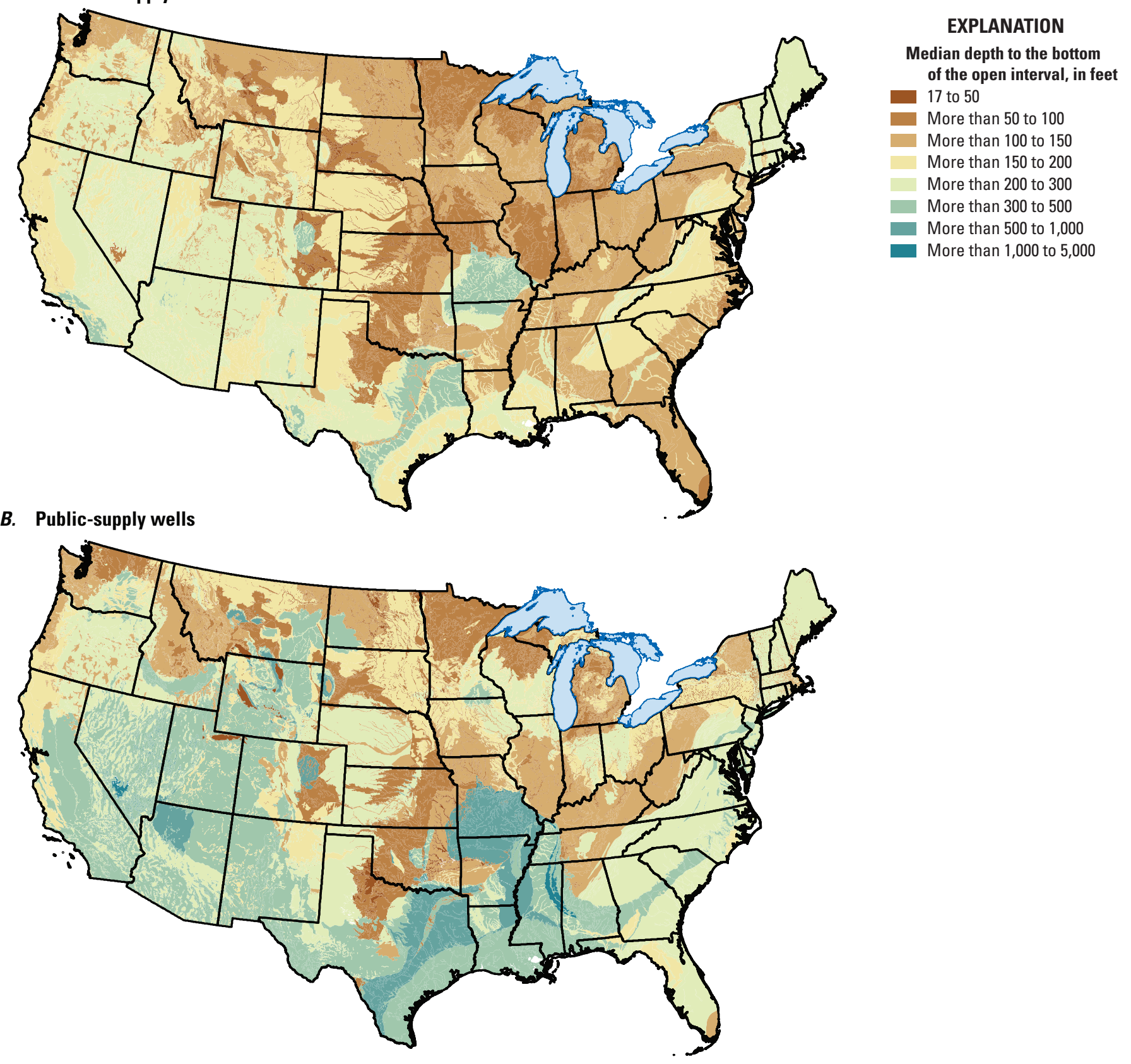

Figure 10. Maps showing the median depth to the bottom of the open interval of wells used for drinking water for each hydrogeologic setting by $A$, domestic- and $B$, public-supply wells in the conterminous United States. Hydrogeologic setting names and locations are identified in figure 1.1 of this report. 


\section{A. Domestic-supply wells}

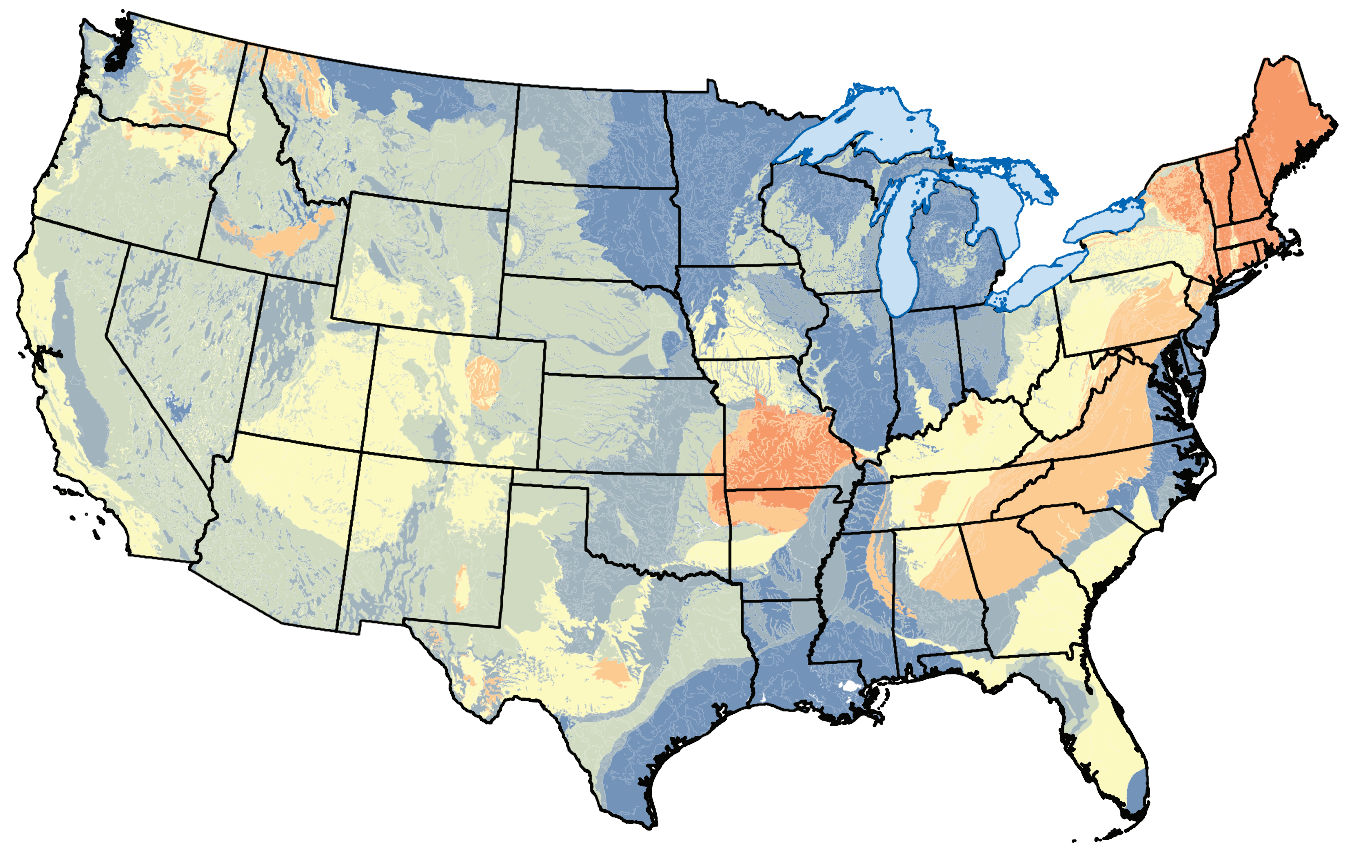

\section{EXPLANATION}

Median length of the open interval, in feet

4 to 10

More than 10 to 25

More than 25 to 50

More than 50 to 100

More than 100 to 200

More than 200 to 500

More than 500 to 2,602

\section{B. Public-supply wells}

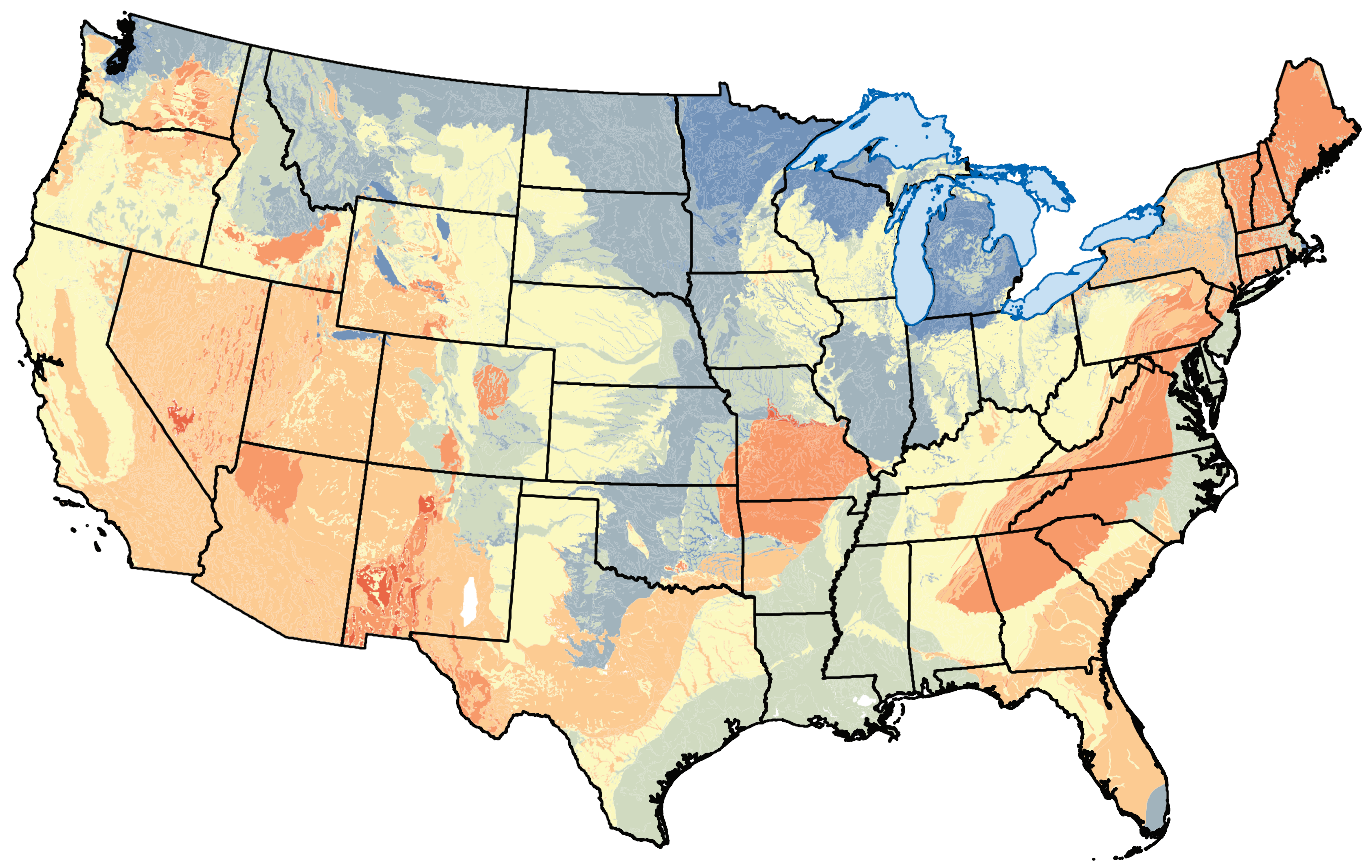

Figure 11. Maps showing the median length of the open interval in wells used for drinking water for each hydrogeologic setting by $A$, domestic- and $B$, public-supply wells in the conterminous United States. Hydrogeologic setting names and locations are identified in figure 1.1 of this report. 


\section{A. Basin-fill aquifer}

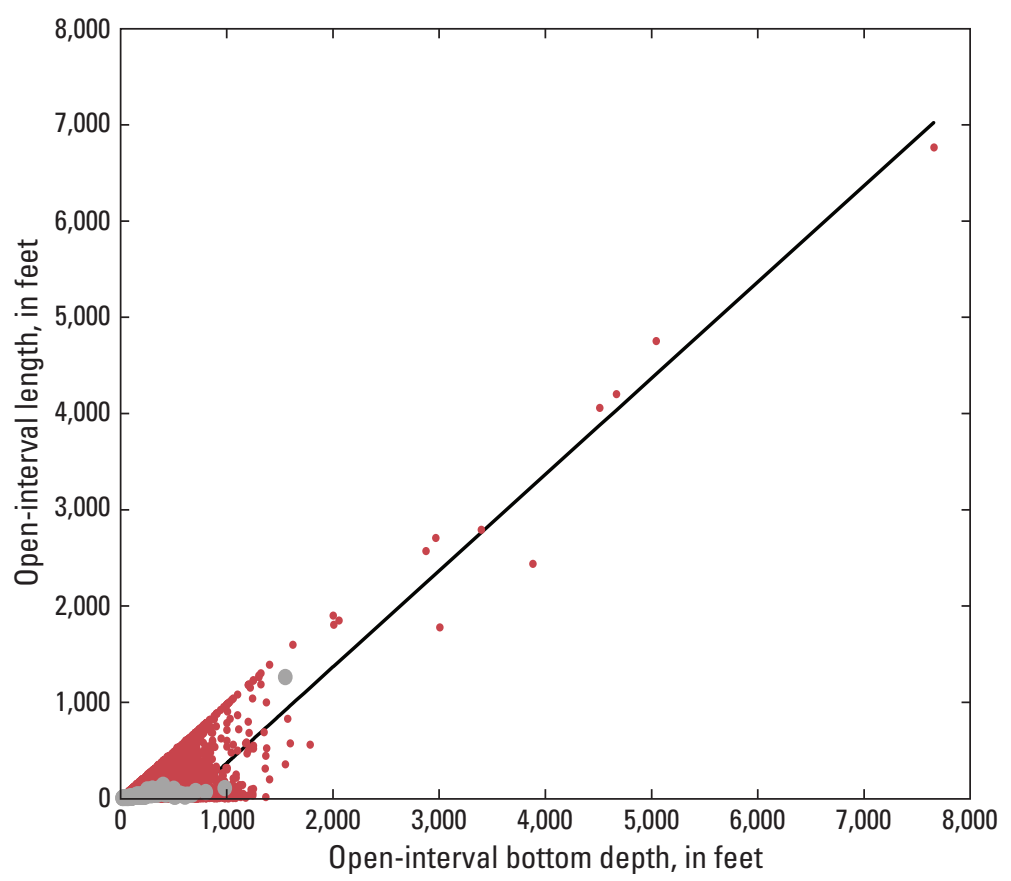

EXPLANATION

- Best-fit line

- Moving median

B. Valley-fill aquifer

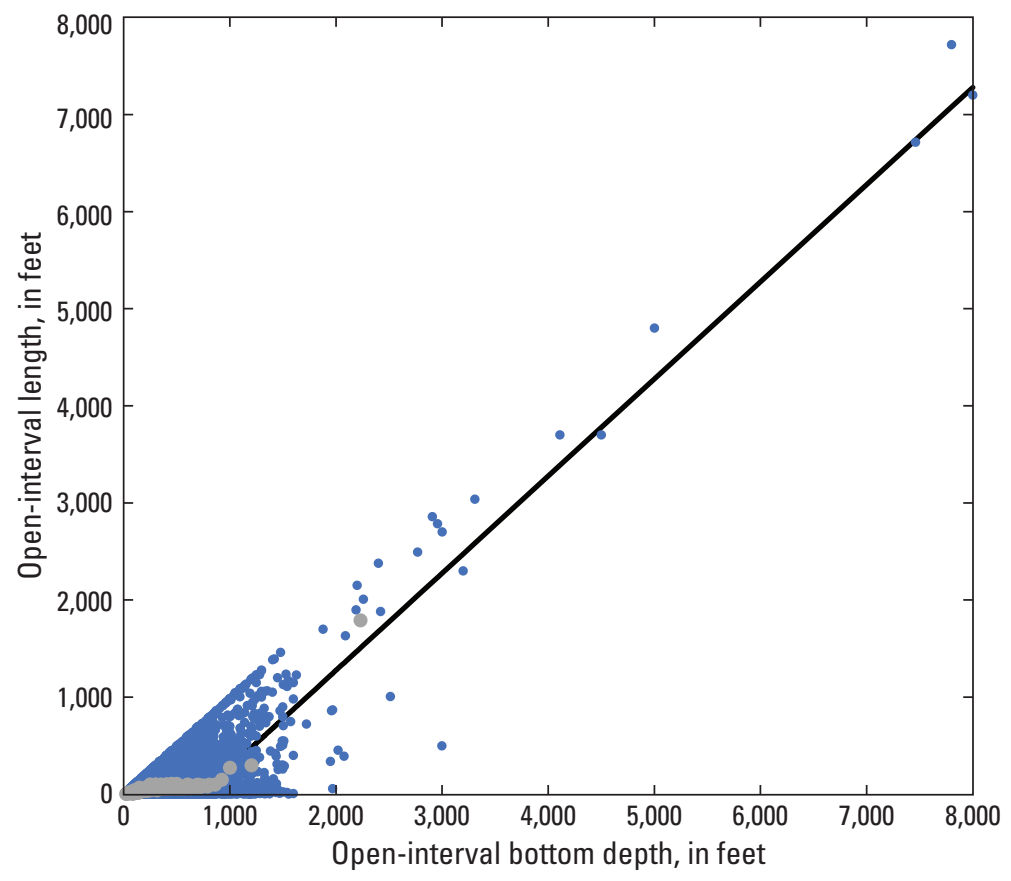

Figure 12. Graphs showing an example of a bimodal relation between open interval length and well depth (best fit shown with black line) for domestic-supply wells in the $A$, Basin and Range basin-fill aquifer and $B$, Basin and Range basin-fill aquifer with overlying stream valley alluvium, in the conterminous United States. Hydrogeologic setting names and locations are identified in fig. 1.1 $\mathrm{H}$ of this report. 


\section{A. Domestic-supply wells}

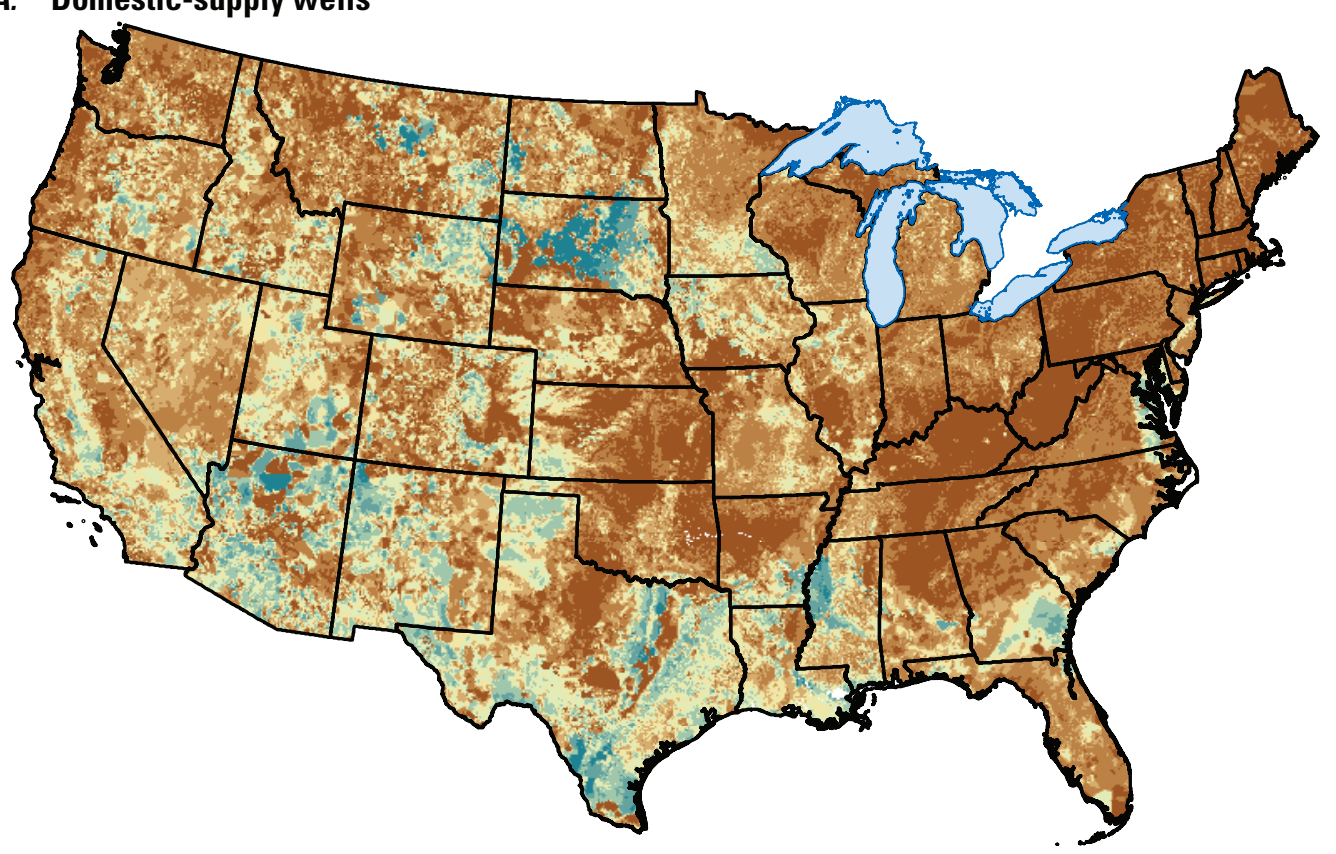

\section{EXPLANATION}

Median depth to top of open interval, in feet

10 to 50

More than 50 to 100

More than 100 to 150

More than 150 to 200

More than 200 to 300

More than 300 to 500

More than 500 to 1,000

More than 1,000

\section{B. Public-supply wells}

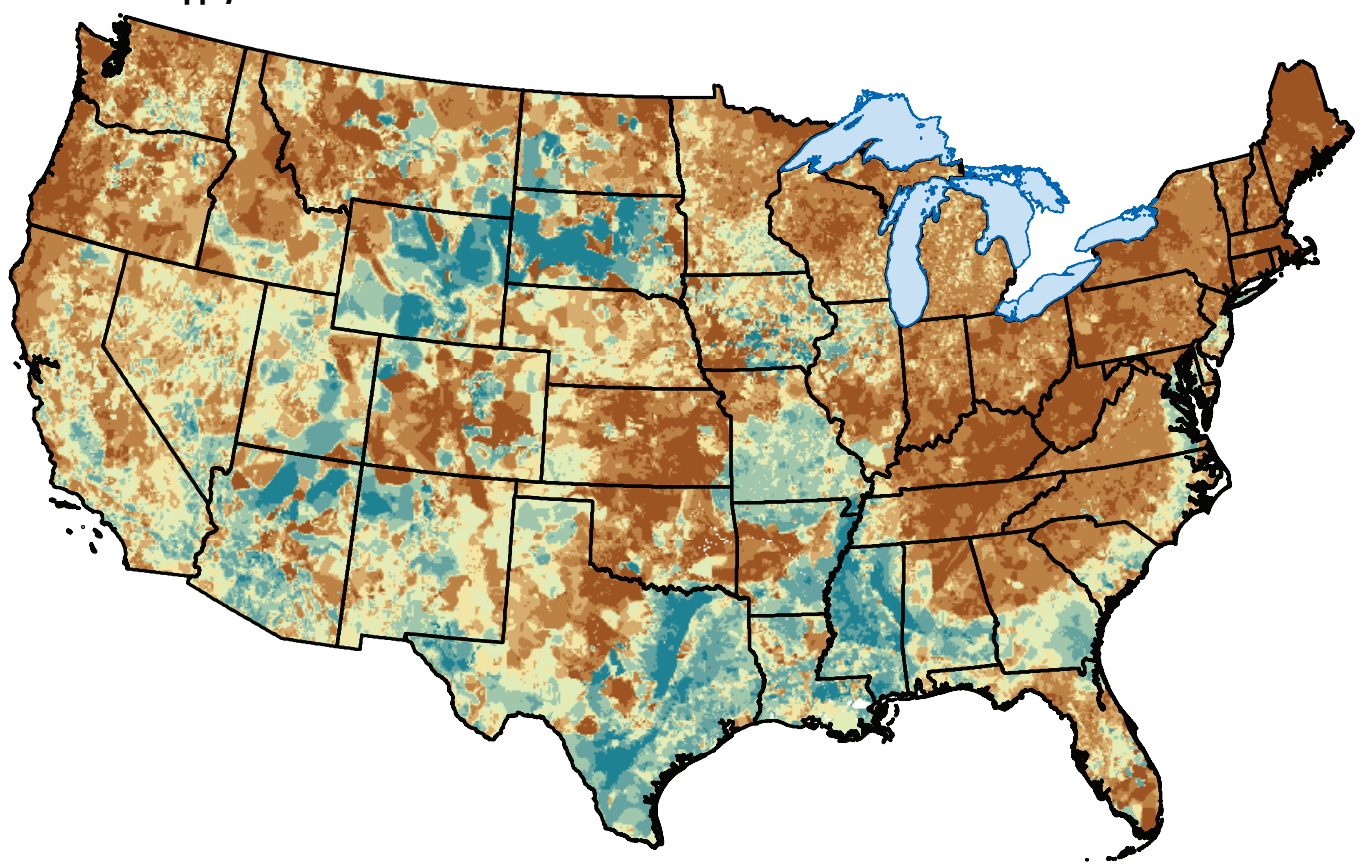

Figure 13. Maps showing the moving median of the depth to the top of the open interval of $A$, domestic- and $B$, public-supply wells in the conterminous United States. The grids in these maps are also accessible in an interactive searchable map at https://doi.org/10.3133/ sir20215069. 


\section{A. Domestic-supply wells}

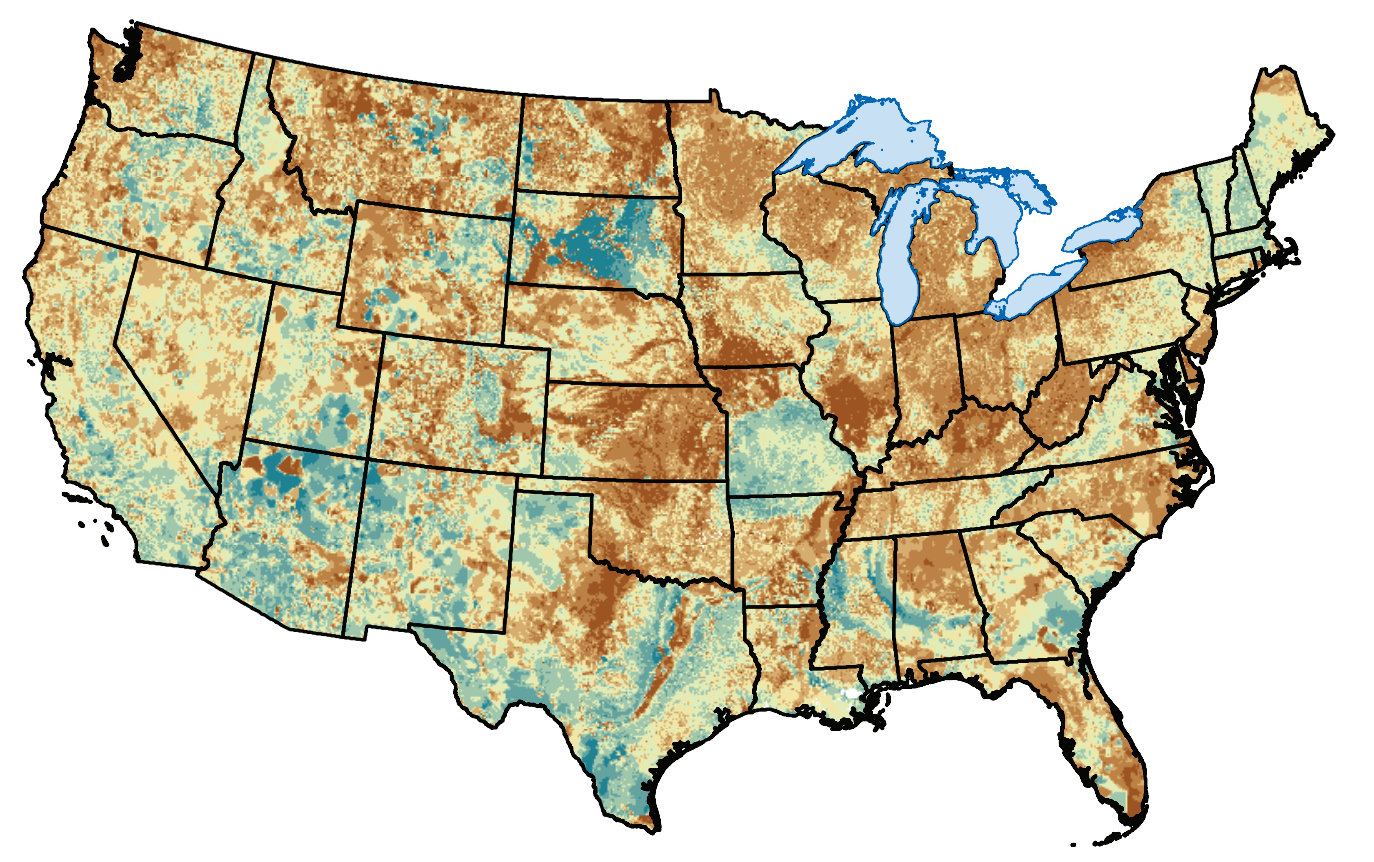

EXPLANATION

Median depth to the bottom of the open interval, in feet

10 to 50

More than 50 to 100

More than 100 to 150

More than 150 to 200

More than 200 to 300

More than 300 to 500

More than 500 to 1,000

More than 1,000

\section{B. Public-supply wells}

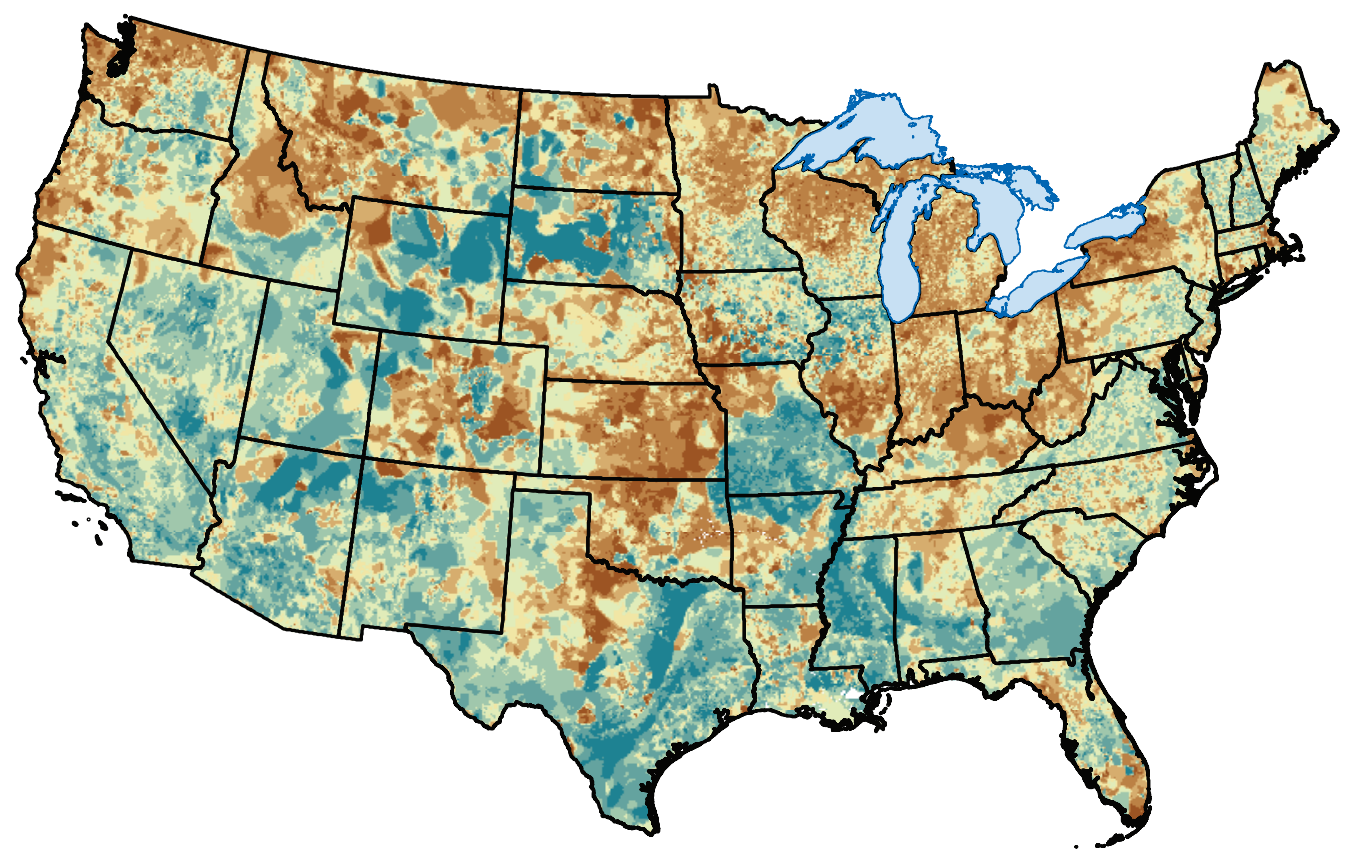

Figure 14. Maps showing the moving median of the depth to the bottom of the open interval of $A$, domestic- and $B$, public-supply wells in the conterminous United States. The grids in these maps are also accessible in an interactive searchable map at https://doi.org/ $10.3133 /$ sir20215069. 
A. Domestic-supply wells

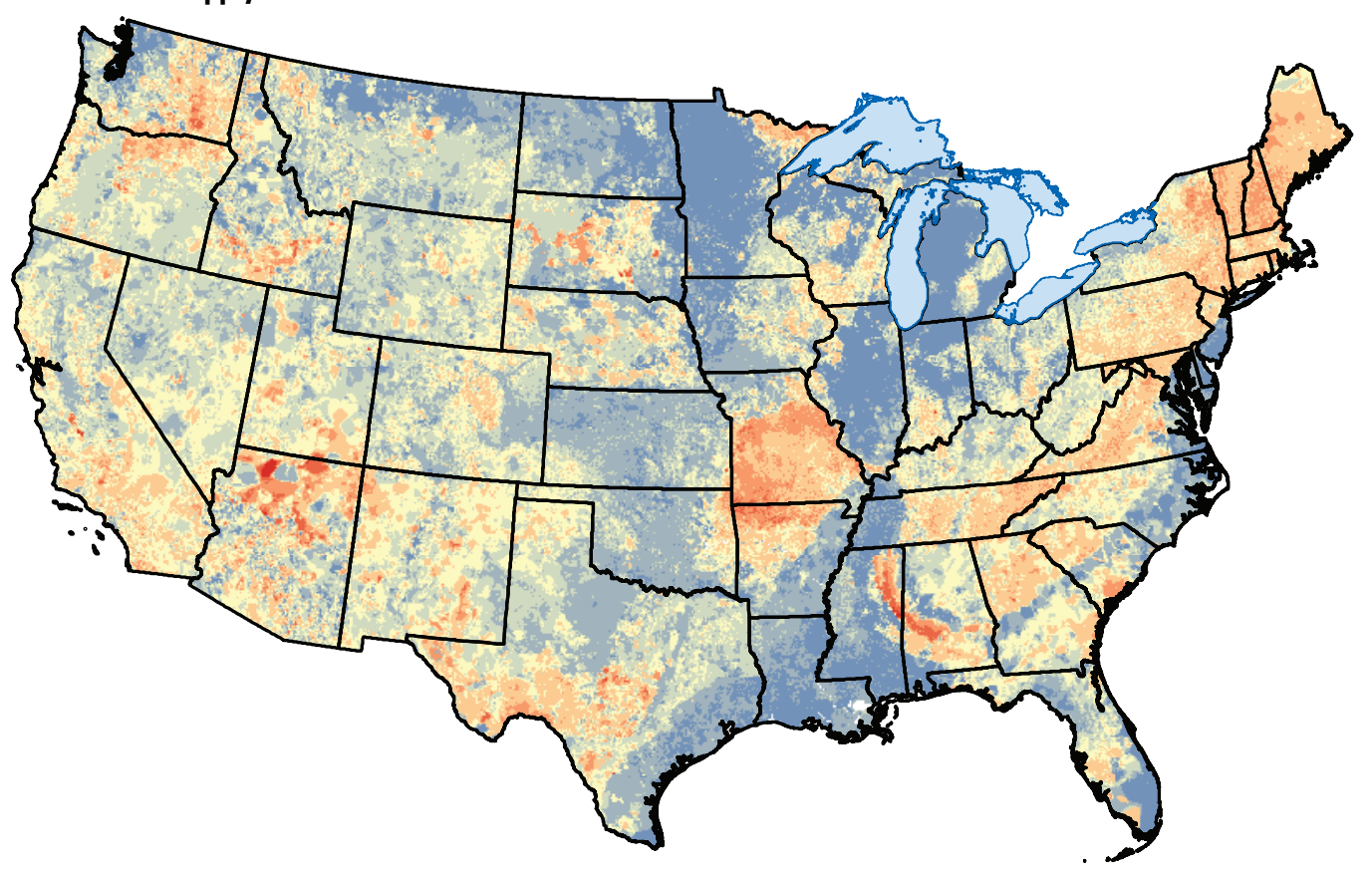

EXPLANATION

Median open interval length, in feet

0 to 10

More than 10 to 25

More than 25 to 50

More than 50 to 100

More than 100 to 250

More than 250 to 500

More than 500 to 1,000

More than 1,000

\section{B. Public-supply wells}

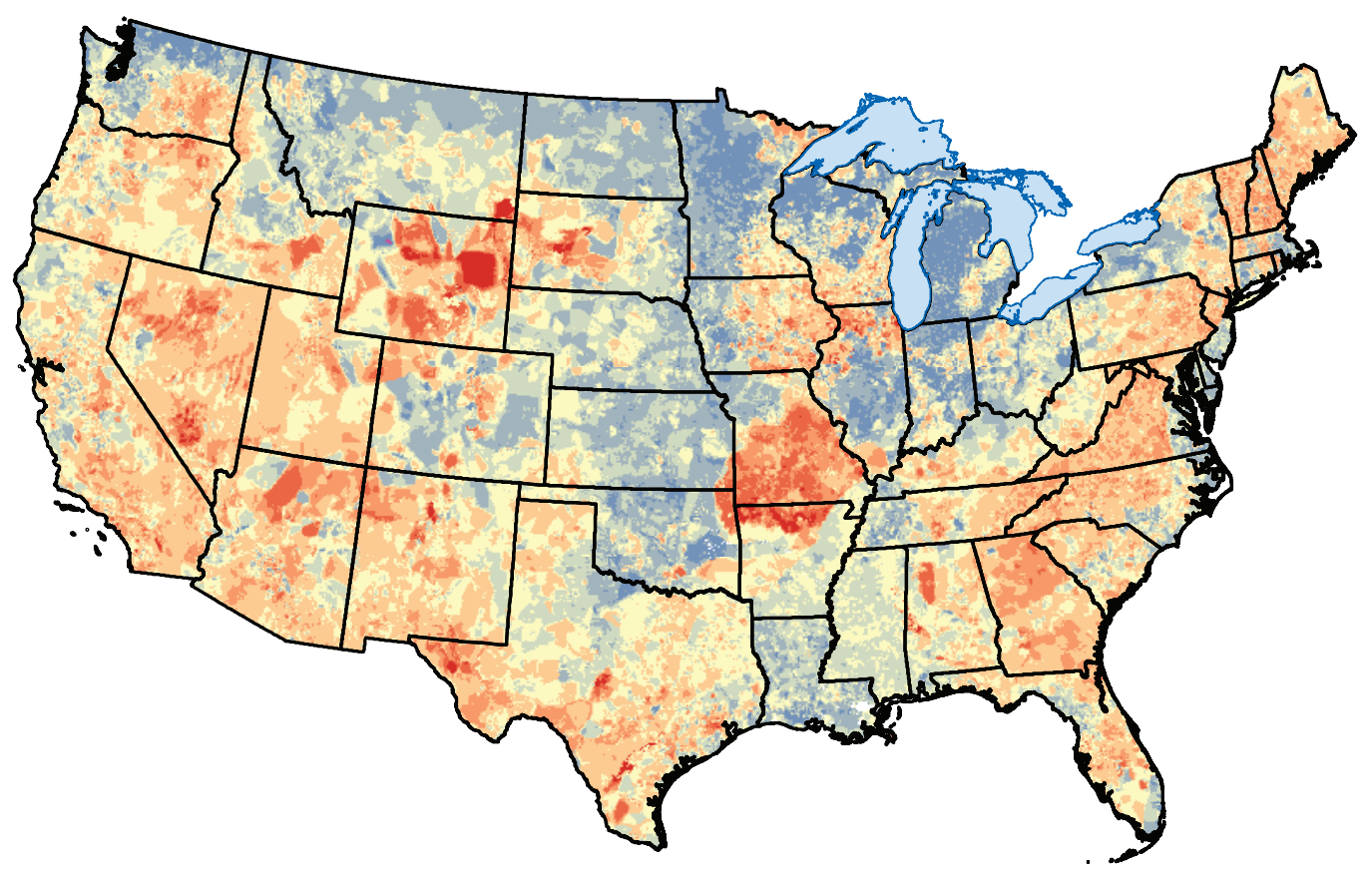

Figure 15. Maps showing the moving median of the open interval length of $A$, domestic- and $B$, public-supply wells in the conterminous United States. The grids in these maps are also accessible in an interactive searchable map at https://doi.org/10.3133/sir20215069. 
water-bearing rocks. Therefore, the smoothed interpolated grids reflect the underlying data. Similarly, open interval depths and lengths in the Ozarks karst system centered in Missouri were among the deepest and longest in the United States, which is reflected in the interpolated grids (figs. 13-15 and 1.1). In contrast, the top and bottom of the open intervals of typical wells are shallow in areas of Nebraska and Kansas in the alluvial valley hydrogeologic setting (figs. 13 and 14). Shorter open intervals are evident in the open interval grids in the North Atlantic and Southeast Coastal Plain, Coastal Lowlands, Mississippi Embayment, and the High Plains principal aquifers and in much of the glaciated area where wells produce water from thin permeable layers (figs. 15 and 1.1).

Patterns in the difference in the typical-well open interval grids help identify areas where domestic- and public-supply wells might produce water from a different aquifer or from different parts of the same aquifer within a hydrogeologic setting (fig. 16). Information regarding where different resources may be in use could help improve our understanding of differences in water quality or availability. In addition, these spatial patterns in the grids take the shape of recognizable geologic formations where higher densities of wells exist. In general, public-supply wells are deeper and have longer open intervals than domestic-supply wells; however, this might not be the case in areas where the shallow overlying alluvium, glacial sediment, or coarse glacial sediment are the most productive aquifers. Some of these features are of limited areal extent and therefore can be more easily targeted by municipalities with greater flexibility in the selection of well location than individual homeowners on small properties. Such areas are most prevalent in the northern glaciated and western mountainous regions of the United States.

\section{Domestic Supply}

At the national scale, some principal aquifer extents are identifiable in the domestic-supply well grid patterns, such as the deeper top and bottom grids in the Denver Basin in east-central Colorado (figs. 13 and 14). In the east, banding associated with the Piedmont and Blue Ridge principal aquifer in the domestic-supply well bottom-depth grid can be seen when zoomed in to New Jersey, Pennsylvania, and Virginia (fig. $13 \mathrm{~A}$ and 14A). Deep domestic-supply wells are indicated by a visibly deep depth grid in the Imperial Valley, California, on the eastern half of the southern border with Mexico (fig. 13A).

\section{Public Supply}

At the national scale, the extents of some large principal aquifers are identifiable in depth patterns (figs. $13 B$ and $14 B$ ) in the public-supply well grid patterns, such as those for the Basin and Range principal aquifers in Nevada (alternating shallow and deep bands) and Colorado Plateaus (relatively shallow area). The well-density-dependent smoothing factor pattern is observable as artifacts (such as straight lines or large polygons in the grid with the same value) in the public-supply well grids at the national scale in a triangular area between western North Dakota, northwestern Texas, and Idaho where the data are not as dense (figs. 13B, 14B, and 15B). Many principal aquifers are distinguished by a characteristic depth that is reflected in the grids. For example, the High Plains aquifer is observable as an area of shallower wells in the public-supply well grid in north central Texas, Oklahoma, and Kansas (figs. 13B, 14B, and fig. 1.1). Similarly, the outline of the Coastal Lowlands, Mississippi Embayment, Southeastern Coastal Plain and Northern Atlantic Coastal Plain principal aquifers is apparent in the public-supply well top of open interval grid as a deep zone of drinking-water supplies (figs. $14 B$ and 1.1). A deep anomaly in the grid extends from South Dakota through Wyoming, Utah, and Arizona (figs. 13B and $14 B$ ). The Edwards-Trinity principal aquifer in Texas appears as a relatively deep area in the public-supply well open interval grids (figs. 13B, 14B, and 1.1). 
A. Depth to top of open interval

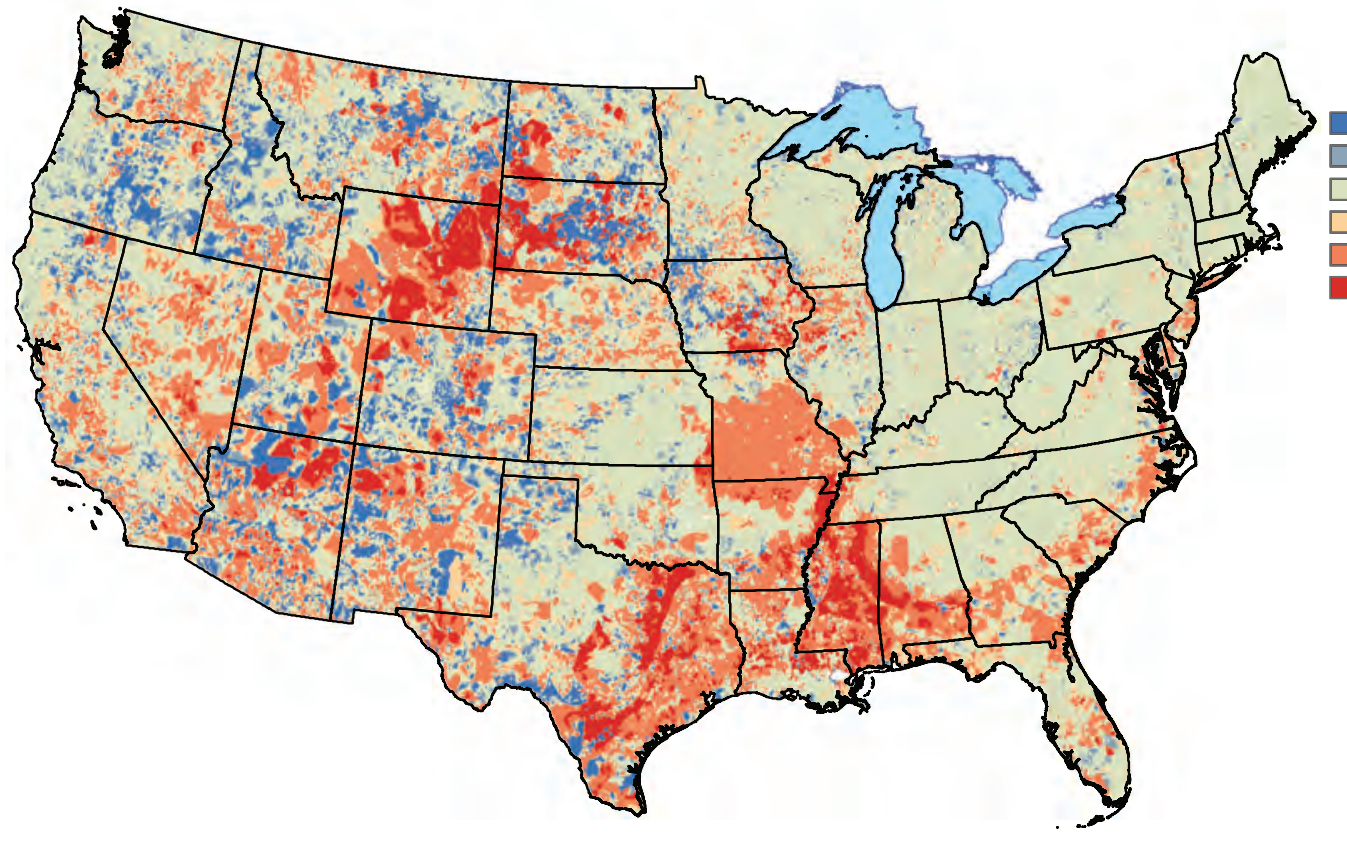

EXPLANATION

Difference between public-supply and domestic-supply median values, in feet

Less than -100

More than -100 to -50

More than -50 to 50

More than 50 to 100

More than 100 to 500

More than 500

\section{B. Depth to bottom of open interval}

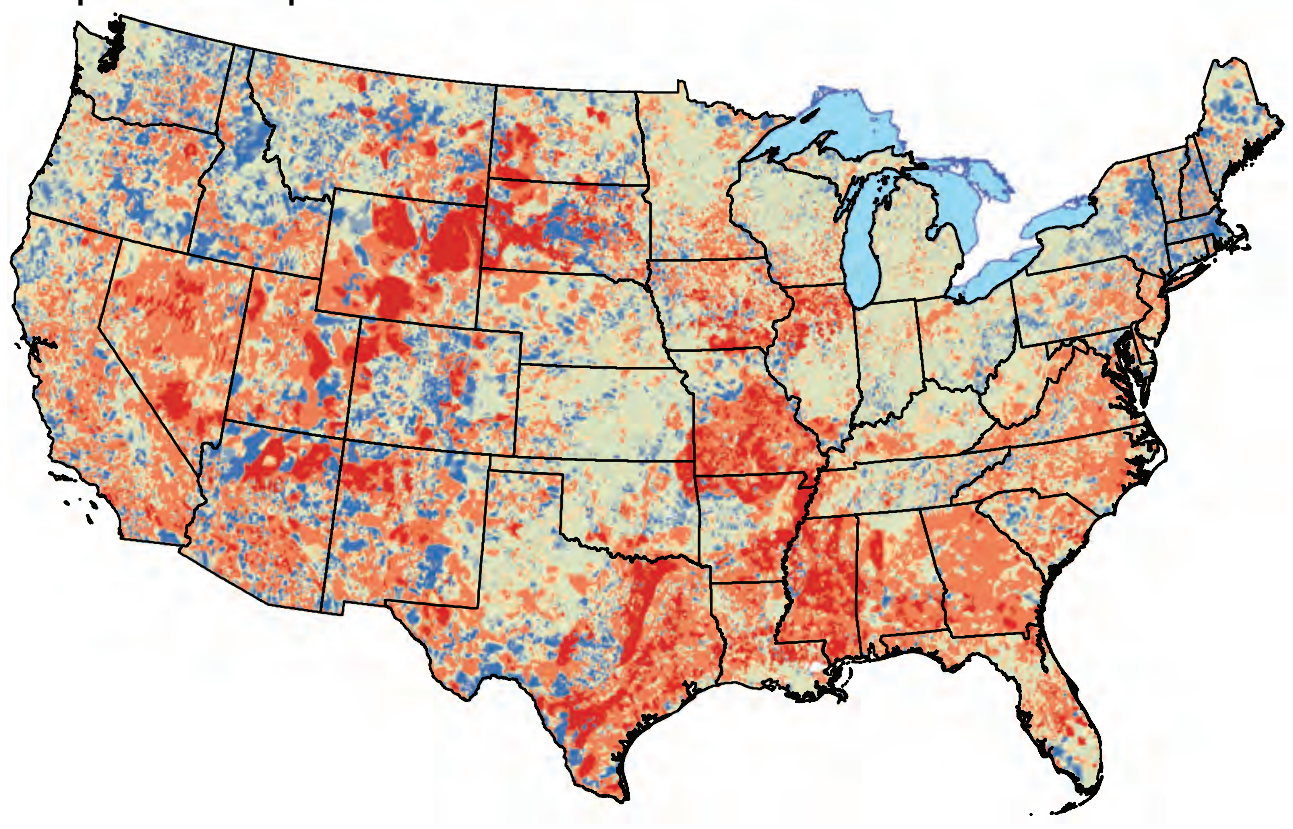

Figure 16. Maps showing the differences (subtraction) between the moving median grids for $A$, depth to the top, $B$, depth to the bottom, and $C$, length of the open interval in domestic- and public-supply wells in the conterminous United States. The grids in these maps are also accessible in an interactive searchable map at https://doi.org/10.3133/sir20215069. 
C. Open-interval length

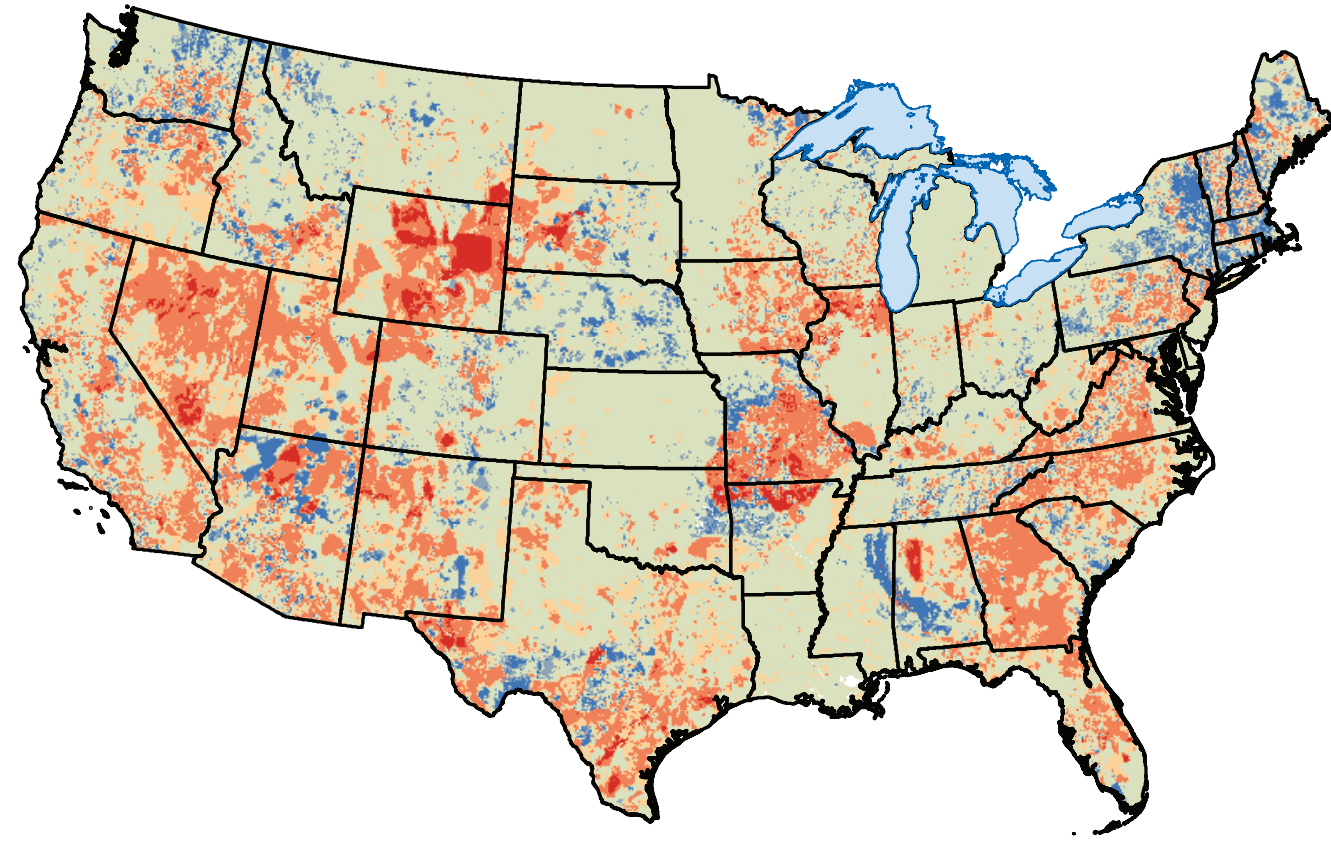

EXPLANATION

Difference between public-supply and domestic-supply median values, in feet Less than -100 More than -100 to -50 More than -50 to 50 More than 50 to 100 More than 100 to 500 More than 500

Figure 16.-Continued

\section{Discussion}

\section{Effect of Overlying Sediment on Depths of Open Intervals in Wells}

The presence of coarse sand and gravel deposits can influence the depth to which wells are drilled in some secondary hydrogeologic regions. The shallowest median depths of domestic-supply wells are in the secondary hydrogeologic regions with overlying coarse glacial sediment, which suggested that the wells are completed in the permeable coarse glacial sediment and not in the secondary hydrogeologic region below. Where coarse glacial sediment overlies secondary hydrogeologic regions with sedimentary, crystalline, and volcanic lithology, median open interval lengths for domesticsupply wells were the shortest, which also indicated that many of the wells were completed in the overlying coarse glacial sediment or with open intervals in both the coarse glacial sediment and the secondary hydrogeologic region. The secondary hydrogeologic regions typically are not permeable enough for wells with short open intervals to produce an adequate water supply unless overlying water-bearing sediment is also present.

Public-supply wells were completed at relatively shallow median depths when they were in secondary hydrogeologic regions with permeable sediment overlying crystalline, sedimentary, and volcanic rock aquifers. When public-supply wells were completed in principal aquifers where permeable aquifers are overlain by fine sediment or clay, the median depths were greater (table 3 ). The median lengths of open intervals in public-supply wells for each hydrogeologic setting lithology are longer than those in domestic-supply wells except for wells in crystalline rock aquifers. Shorter open intervals in public-supply wells completed in crystalline lithology hydrogeologic settings are likely a consequence of the wells actually being completed in the overlying sediments above the crystalline rock aquifers rather than in the crystalline rock aquifers themselves.

\section{Characteristics of Wells in Glacial Aquifer Systems}

Withdrawal zones in drinking-water supply wells in the glacial aquifer systems overlie bedrock aquifers across the northern United States (Stackelberg and others, 2021); in many areas, including the central interior geologic province (fig. 1), such zones are the primary drinking-water sources (Erickson and others, 2019). Statistical models have been developed to characterize the properties of groundwater in the glacial aquifer systems, including models for $\mathrm{pH}$, redox conditions, and concentrations of selected constituents, such as arsenic and manganese. Results of those model simulations are presented in maps of predictions of the water-quality characteristics at depths relevant to drinking-water supply (Erickson and others, 2019; Stackelberg and others, 2021); therefore, it was necessary to generate a glacial aquifer system-specific set of domestic- and public-supply well depth grids in order to help use and interpret the simulation results. The glacial 
aquifer system drinking-water well depth grids are an example of distinguishing aquifer-specific drinking-water supply zones in a stacked aquifer system.

The glacial aquifer system open interval grids (Stackelberg and others, 2021) were generated using methods similar to those used in this study and were based on depth data for about 1.2 million domestic-supply wells and about 69,000 public-supply wells. Records for approximately 820,000 domestic-supply wells and 41,000 public-supply wells included data on the length of the open interval. The wells withdrawing water from the glacial aquifer systems are a subset of the total dataset used in this study. Withdrawal zones identified in this study are the same in some areas where the glacial aquifer system is the primary source and vary in other areas where there are stacked aquifers or where the glacial aquifer system is not used as a drinking-water supply. Briefly, several attributes were used to distinguish a well producing water from a glacial aquifer rather than from a principal aquifer or secondary hydrogeologic region: national and local aquifer names, aquifer type (sand and gravel, till, or bedrock, for example), and open interval depth less than depth to bedrock (Yager and others, 2018). In addition, well depths were compared to the depth to the top of bedrock or to the bottom of overlying Quaternary sediments to distinguish aquifer type.

The glacial aquifer system consists of sediments of varying composition and complexity-factors that can influence well characteristics such as depths and open intervals - so grouping areas were created considering wells that produce water from the glacial aquifer. The grouping areas are unique to the glacial aquifer system and represent a stacked aquifer that is above the hydrogeologic setting used to process data in this study. The grouping area was determined on the basis of the hydrogeologic terrane and whether the Quaternary sediment is classified as coarse grained stratified or not (Haj and others, 2018). The glacial aquifer system researchers used methods similar to those used in this study to choose a target number of wells (five) for each cell to use for depth and length median calculation, by first considering the wells within the cell. Stackelberg and others (2021) also used a smoothing algorithm, similar to that used in this study, to create the glacial aquifer system grids by averaging each cell using two cells in each direction, or a $5 \times 5$ grid of cells. While not changing the overall structure of the data, this smoothing procedure helped remove local anomalies.

Comparing the glacial aquifer system-specific drinkingwater depth grids with the depth grids on a national scale illustrated where bedrock aquifers are more commonly used than glacial aquifers. For example, the moving median depth of domestic-supply drinking-water wells as determined by Stackelberg and others (2021) is much shallower on a national basis than for wells in the glacial aquifer systems in areas where glacial sediment is thin as determined in the present study. Areas with thin glacial sediment include the northern New England States, northeastern and southeastern Minnesota, southwestern Wisconsin, and northern Missouri, which primarily use bedrock wells for drinking-water supply. Another notable difference between the glacial aquifer system and the national drinking water grids is that domestic- and public-supply well depths are more similar in the glacial aquifer system than nationally. In the national study, the depths of public-supply wells are significantly greater than those of domestic-supply wells, especially in western and southeastern States.

\section{Data Gaps and Limitations}

Well data used in the analyses in this study were limited to those data available from national or State digital databases. The $1-\mathrm{km}^{2}\left(0.38-\mathrm{mi}^{2}\right)$ resolution of grids that define the depth to open intervals in drinking-water wells was chosen because it is a common model scale and sizes are functional at the national scale. This resolution does not represent the accuracy of the grid, which varies and is limited by well data density. In general, areas with sparse populations have sparse well density. Results from this study show the density of data for and estimates of locations of domestic-supply wells to be similar to those in studies of small-scale or regional studies, for example, studies in northern Maine, inland in southern Florida, and in broad expanses west of the continental divide (Johnson and Belitz, 2017; Johnson and others, 2019). Data for wells used for other than a drinking-water source, such as for irrigation, were available in areas of sparse data and could be used for filling in data gaps by using a correction factor. Machine-learning models may also have the potential for filling in gaps in well data with predictions of the open interval length and depth using geologic, physiographic, topographic, and hydrologic position variables (Belitz and others, 2019a).

Several quality-assurance and data-decision steps were performed during data compilation to select data to include. However, exhaustive quality assurance to help fill in missing records for each of the data sources was outside the scope of this study. Other well records, in paper or scanned form, were not used. Many of the State digital datasets were not developed until the 1980s, and they commonly do not include records for older wells. For example, in the northeastern United States, dug wells completed in till account for only about 0.4 percent of the documented water supply for the region. In many rural areas, dug wells are still in use but may not have been reported, and they were the only available groundwater supply before the technology to drill bedrock wells became widespread (Olcott, 1995; U.S. Geological Survey, 2003).

Well drilling and construction methods have changed over time and with advances in technology. For example, older bedrock wells were commonly drilled to shallow depths with a cable-tool (or percussion) rig, whereas newer bedrock wells are commonly drilled deeper with air rotary rigs to intercept more water-bearing zones and thus meet an increasing demand for additional yield (Moore and others, 2002). Older hand-dug wells in glacial material had stone casings and often were not recorded; this type of well is now constructed with excavators and lined with concrete tiles. The newest technology for completing dug wells in glacial till incorporates a sanitary design 
that creates additional storage by placing a large volume of crushed stone around a small-diameter well casing during construction (Winston and Ayotte, 2018; Carlisle and others, 2019). Unlike bedrock wells, depths of wells in shallow till have not changed over time with advances in technology. Drill date and method information were sometimes included in the source datasets and could be used to help understand variations in open interval length and depth relations, but are not used in this study.

The principal results of the analyses described and illustrated in this report are the open interval grids for domesticand public-supply wells. Although multiple (or stacked) aquifers are present in many areas in the United States, the results presented here are intended to represent the most commonly used aquifer or aquifers in an area and therefore indicate the open intervals with the highest documented number of wells for each use. Only one withdrawal zone is represented with one set of open interval grids, but the grids may represent different aquifers within a single hydrogeologic setting as one undulating or aquifer cross cutting set of grids. Separate stacked aquifers, for example, are not accounted for in the multiple stacked principal aquifers or multiple aquifers within principal aquifers, such as the Central Valley in California, the North Atlantic Coastal Plain, and the Coastal Lowlands of Texas and Louisiana (fig. 1.1 $H, B$, and $C$, respectively). In the Coastal Lowlands principal aquifer along the coasts of Texas and Louisiana, the aquifer bottom grid appears as a rough but horizontal plane (fig. 13), but the plane cuts across several dipping aquifer layers.

Well depths in this study were not compared with the Quaternary thicknesses (Yager and others, 2018) as they were for the glacial aquifer system open interval grid generation (Stackelberg and others, 2021). Mapped aquifer top and bottom grids and other hydrogeologic information that could be used to constrain the depth of drinking-water-supply wells also were not used. State and regional maps of depth to bedrock (DiGiacomo-Cohen and others, 2020), which could be used to constrain the bottom of well screens in unconsolidated material or the top of productive zones in bedrock aquifers, were not used in this effort. Grids of the depths of open intervals in drinking-water-supply wells presented in this report represent the typical open interval of wells in use and not the total potential developable resource. The difference between the moving median grids and actual aquifer withdrawal zones within the aquifer could be identified by a more comprehensive examination of the hydrogeologic data analyzed in this study.

\section{Summary}

Understanding the distribution of drinking-water supplies from a groundwater source is important to protect human health, plan resource development, and reduce treatment costs. Thirty-five percent of drinking-water supplies in the United
States is withdrawn from wells that have a wide range of open interval depths and lengths. This variability in open interval depths and lengths for drinking-water supplies led to a need for a set of grids to represent the depths of the zones used for groundwater withdrawal for domestic- and public-drinkingwater supply within the conterminous United States.

The well data analyzed in this study were limited to those available digitally in national or State datasets. The well data were compiled from several sources, including the National Water Information System, the Safe Drinking Water Information System dataset (primarily data for public-supply wells), a groundwater ambient monitoring dataset (primarily data for domestic-supply wells), datasets from individual States, a national brackish aquifer study, and a study of glacial aquifer systems. General spatial patterns of the density of data for domestic-supply wells determined in the study in this report closely matched the density of such data estimated in an earlier study, indicating that the dataset in this report is representative of domestic-supply wells in use in the United States.

Fifty-seven principal aquifers and 65 secondary hydrogeologic regions were merged with overlying sediment polygons to generate 288 unique hydrogeologic settings across the conterminous United States that vary in depth, thickness, lithology, and transmissivity characteristics. Some principal aquifers and secondary hydrogeologic regions overlie one another, and some are also overlain by glacial sediment, coarse glacial sediment, or stream valley alluvium, which in themselves may be used as drinking-water-supply sources. Understanding how hydrogeologic settings are based on mappable geology and align with physiography and topography in most places aided the understanding of aquifer boundaries and potential aquifer groupings. Each well was assigned to a hydrogeologic setting based on location, and hydrogeologic setting well groupings were used to assess well depth and open interval data. When well data within a hydrogeologic setting were sparse or missing, data from an adjacent or nearby hydrogeologic setting with similar well-construction properties, geology, physiography, and topography were used to estimate the median open interval parameters and to generate moving median grids. Depths to and lengths of open intervals in areas having sparse data were also estimated using a two-slope linear function developed from available data to represent the typical relation between the depth of the bottom of the open interval and the length of the open interval. Grids of moving median values for the depths to and lengths of open intervals in wells were generated at a 1-square-kilometer (0.38-square-mile) grid cell scale.

Comparisons between open interval lengths and depths in domestic-supply and public-supply wells showed several notable differences. Median depths and open intervals of domestic- and public-supply wells varied by an order of magnitude by lithology of the hydrogeologic setting and the overlying sediment across the conterminous United States. The overall median well depths were 142 feet (43.3 meters) for domestic-supply wells and 202 feet (61.6 meters) for public-supply wells. The median lengths of open intervals 
were 21 feet (6.4 meters) for domestic-supply wells and 49 feet (14.9 meters) for public-supply wells. The median depths of public-supply wells in each major rock type in principal aquifers are deeper than the median depths of domesticsupply wells. The shallowest median depths of domesticsupply wells are in the secondary hydrogeologic regions overlain by coarse glacial sediment, indicating that the wells are completed in the overlying sediment and not the secondary hydrogeologic region below. Similarly, public-supply wells were completed at shallower median depths when they were in areas of permeable overlying sediment that blanketed crystalline, sedimentary, and volcanic rock secondary hydrogeologic regions. The median depths of public- and domestic-supply wells completed in crystalline and volcanic rock secondary hydrogeologic regions (without any overlying sediment) are similar, except that where the secondary hydrogeologic region is overlain by permeable deposits, the public-supply wells are slightly less deep. When public-supply wells were completed in principal aquifers, however, the median depths were typically deeper than domestic-supply wells.

Separate sets of grids defining the open intervals of drinking-water-supply wells are presented for both domesticand public-supply wells. Although multiple overlying (or stacked) aquifers are present in many areas, results presented here are not separated by stacked aquifers and highlight the aquifer or aquifers that are most commonly used for drinking water supply in a particular area.

\section{Acknowledgments}

This work was funded by the U.S. Geological Survey (USGS) National Water-Quality Assessment Project, a component of the National Water Quality Program. The authors thank all USGS colleagues who assisted with and supported this project, including John Wilson for help with coordinating data from the individual States; James Reddy and Tyler Johnson for focusing and clarifying the report by their colleague reviews; and Jennifer Sharpe for assistance in designing and formatting the data release.

\section{References Cited}

Ayotte, J.D., Gronberg, J.A.M., and Apodaca, L.E., 2011, Trace elements and radon in groundwater across the United States, 1992-2003: U.S. Geological Survey Scientific Investigations Report 2011-5059, 115 p., accessed April 21, 2021, at https://doi.org/10.3133/sir20115059.
Ayotte, J.D., Medalie, L., Qi, S.L., Backer, L.C., and Nolan, B.T., 2017, Estimating the high-arsenic domestic-well population in the conterminous United States: Environmental Science \& Technology, v. 51, no. 21, p. 12443-12454, accessed March 19, 2021, at https://doi.org/10.1021/ acs.est. $7 b 02881$.

Ayotte, J.D., Nolan, B.T., and Gronberg, J.A.M., 2016, Predicting arsenic in drinking water wells of the Central Valley, California: Environmental Science \& Technology, v. 50, no. 14, p. 7555-7563, accessed March 19, 2021, at https://doi.org/10.1021/acs.est.6b01914.

Bayless, E.R., Arihood, L.D., Reeves, H.W., Sperl, B.J.S., Qi, S.L., Stipe, V.E., and Bunch, A.R., 2017, Maps and grids of hydrogeologic information created from standardized water-well drillers' records of the glaciated United States: U.S. Geological Survey Scientific Investigations Report 2015-5105, 34 p., accessed April 21, 2021, at https://doi.org/10.3133/sir20155105.

Belitz, K., Moore, R.B., Arnold, T., Sharpe, J.B., and Starn, J.J., 2019a, Multiorder hydrologic position in the conterminous United States-A set of metrics in support of groundwater mapping at regional and national scales: Water Resources Research, v. 55, no. 12, p. 11188-11207, accessed March 19, 2021, at https://doi.org/10.1029/ 2019WR025908.

Belitz, K., Watson, E., Johnson, T.D., and Sharpe, J.B., 2019b, Secondary hydrogeologic regions of the conterminous United States: Ground Water, v. 57, no. 3, p. 367-377, accessed March 19, 2021, at https://doi.org/10.1111/ gwat.12806.

Brown, C.J., Barlow, J.R.B., Cravotta, C.A., III, and Lindsey, B.D., 2019, Factors affecting the occurrence of lead and manganese in untreated drinking water from Atlantic and Gulf Coastal Plain aquifers, eastern United StatesDissolved oxygen and $\mathrm{pH}$ framework for evaluating risk of elevated concentrations: Applied Geochemistry, v. 101, p. 88-102, accessed April 21, 2021, at, https://doi.org/ 10.1016/j.apgeochem.2018.10.017.

Bruce, B.W., and Oelsner, G.P., 2001, Contrasting water quality from paired domestic/public supply wells, central High Plains: Journal of the American Water Resources Association, v. 37, no. 5, p. 1389-1403, accessed March 19, 2021, at https://doi.org/10.1111/j.17521688.2001.tb03647.x. 
Carlisle, I.D., Belaval, M., Gordon, R.P., Simbliaris, H., Bryce, J.G., and Ayotte, J.D., 2019, Groundwater and public health: a novel shallow well technology to provide safe drinking water for private domestic wells, in Geological Society of America, Northeastern Section, 54th Annual Meeting, March 17-19, 2019, Portland, Maine: Geological Society of America Abstracts with Programs, v. 51, no. 1, paper 24-9, 1 p., accessed March 19, 2021, at https://doi.org/10.1130/ abs/2019NE-328066.

Degnan, J.R., Lindsey, B.D., Levitt, J.P, and Szabo, Z., 2020, The relation of geogenic contaminants to groundwater age, aquifer hydrologic position, water type, and redox conditions in Atlantic and Gulf Coastal Plain aquifers, eastern and south-central USA: The Science of the Total Environment, v. 723,15 p., accessed April 21, 2021, at https://doi.org/ 10.1016/j.scitotenv.2020.137835.

DeSimone, L.A., Pope, J.P., and Ransom, K.M., 2020, Machine-learning models to map $\mathrm{pH}$ and redox conditions in groundwater in a layered aquifer system, Northern Atlantic Coastal Plain, eastern USA: Journal of Hydrology: Regional Studies, v. 30, 20 p., accessed April 21, 2021, at https://doi.org/10.1016/j.ejrh.2020.100697.

Dieter, C.A., Maupin, M.A., Caldwell, R.R., Harris, M.A., Ivahnenko, T.I., Lovelace, J.K., Barber, N.L., and Linsey, K.S., 2018, Estimated use of water in the United States in 2015: U.S. Geological Survey Circular 1441, 76 p., accessed April 21, 2021, at https://doi.org/10.3133/cir1441.

DiGiacomo-Cohen, M., Walsh, G.J., Chormann, F.H., Engelhart, S.E., Gale, M.H., Mabee, S.B., Marvinney, R.G., and Thomas, M.A., 2020, An introduction to the New England Top of Rock (NE TOR) project, in Geological Society of America, Joint 69th Annual Southeastern / 55th Annual Northeastern Section Meeting, March 16-23, online: Geological Society of America Abstracts with Programs, v. 52, no. 2, paper 72-3, 1 p., accessed April 21, 2021, at https://doi.org/10.1130/abs/2020SE-344734.

Erickson, M.L., and Barnes, R.J., 2005, Well characteristics influencing arsenic concentrations in ground water: Water Research, v. 39, no. 16, p. 4029-4039, accessed March 19, 2021, at https://doi.org/10.1016/j.watres.2005.07.026.

Erickson, M.L., Elliot, S.M., Brown, C.J., Stackelberg, P.E., Ransom, K.M., Reddy, J.E., and Cravotta, C.A., III, 2021, Machine-learning predictions of high arsenic and high manganese at drinking water depths of the glacial aquifer system, northern continental United States: Environmental Science \& Technology, v. 55, no. 9, p. 5791-5805, accessed October 13, 2021, at https://doi.org/10.1021/ acs.est.0c06740.
Erickson, M.L., Elliott, S.M., Christenson, C.A., and Krall, A.L., 2018, Predicting geogenic arsenic in drinking water wells in glacial aquifers, north-central USA-Accounting for depth-dependent features: Water Resources Research, v. 54, no. 12, p. 172-187, accessed April 21, 2021, at https://doi.org/10.1029/2018WR023106.

Erickson, M.L., Yager, R.M., Kauffman, L.J., and Wilson, J.T., 2019, Drinking water quality in the glacial aquifer system, northern USA: The Science of the Total Environment, v. 694, paper 133735, 14 p., accessed April 21, 2021, at https://doi.org/10.1016/j.scitotenv.2019.133735.

Foster, S.S.D., and Chilton, P.J., 2003, Groundwater-The processes and global significance of aquifer degradation: Philosophical Transactions of the Royal Society of London. Series B, Biological Sciences, v. 358, no. 1440, p. 1957-1972, accessed March 19, 2021, at https://doi.org/ 10.1098/rstb.2003.1380.

Haj, A.E., Soller, D.R., Reddy, J.E., Kauffman, L.J., Yager, R.M., and Buchwald, C.A., 2018, Hydrogeologic framework for characterization and occurrence of confined and unconfined aquifers in quaternary sediments in the glaciated conterminous United States-A digital map compilation and database: U.S. Geological Survey Data Series 1090, 31 p., accessed April 21, 2021, at https://doi.org/10.3133/ds1090.

Helsel, D.R., and Hirsch, R.M., 2002, Statistical methods in water resources: U.S. Geological Survey Techniques of Water-Resources Investigations, book 4, chap. A3, 522 p., accessed April 21, 2021, at https://doi.org/10.3133/ twri04A3.

Johnson, T., and Belitz, K., 2017, Domestic well locations and populations served in the contiguous U.S.-1990: The Science of the Total Environment, v. 607-608, p. 658-668, accessed March 19, 2021, at https://doi.org/ 10.1016/j.scitotenv.2017.07.018.

Johnson, T.D., Belitz, K., and Lombard, M., 2019, Estimating domestic well locations and populations served in the contiguous U.S. for years 2000 and 2010: The Science of the Total Environment, v. 687, p. 1261-1273, accessed March 19, 2021, at https://doi.org/10.1016/j.scitotenv.2 019.06.036.

Kauffman, L.J., Degnan, J.R., Belitz, K., Stackelberg, P.E., and Erickson, M.L., 2021, Data for depth of groundwater used for drinking-water supplies in the United States: U.S. Geological Survey data release, accessed April 21, 2021, at https://doi.org/10.5066/P94640EM.

Kim, D., Miranda, M.L., Tootoo, J., Bradley, P., and Gelfand, A.E., 2011, Spatial modeling for groundwater arsenic levels in North Carolina: Environmental Science \& Technology, v. 45, no. 11, p. 4824-4831, accessed March 19, 2021, at https://doi.org/10.1021/es103336s. 
Mann, H.B., and Whitney, D.R., 1947, On a test of whether one of two random variables is stochastically larger than the other: Annals of Mathematical Statistics, v. 18, no. 1, p. 50-60, accessed March 19, 2021, at https://doi.org/ 10.1214/aoms/1177730491.

Masterson, J.P., Pope, J.P., Fienen, M.N., Monti, J.J., Nardi, M.R., and Finkelstein, J.S., 2016, Assessment of groundwater availability in the Northern Atlantic Coastal Plain aquifer system from Long Island, New York, to North Carolina: U.S. Geological Survey Professional Paper 1829, 76 p., accessed April 21, 2021, at https://doi.org/10.3133/pp1829.

Miller, J.A., 1990, Alabama, Florida, Georgia, South Carolina, seg. 6 of Ground water atlas of the United States: U.S. Geological Survey Hydrologic Atlas 730-G, accessed April 21, 2021, at https://doi.org/10.3133/ha730G.

Miller, J.A., 1999, Introduction and national summary, chap. A of Ground water atlas of the United States: U.S. Geological Survey Hydrologic Atlas 730-A, 15 p., accessed April 21, 2021, at https://doi.org/10.3133/ha730A.

Moore, R.B., Schwartz, G.E., Clark, S.F., Walsh, G.J., and Degnan, J.R., 2002, Factors related to well yield in the fractured-bedrock aquifer of New Hampshire: U.S. Geological Survey Professional Paper 1660, 51 p., accessed April 21, 2021, at https://doi.org/10.3133/pp1660.

Nolan, B.T., and Hitt, K.J., 2006, Vulnerability of shallow groundwater and drinking-water wells to nitrate in the United States: Environmental Science \& Technology, v. 40, no. 24, p. 7834-7840, accessed March 19, 2021, at https://doi.org/10.1021/es060911u.

Nordstrom, D.K., 2002, Worldwide occurrences of arsenic in ground water: Science, v. 296, no. 5576, p. 2143-2145, accessed March 19, 2021, at https://doi.org/10.1126/ science. 1072375.

Olcott, P.G., 1995, Connecticut, Maine, Massachusetts, New Hampshire, New York, Rhode Island, Vermont, seg. 12 of Ground water atlas of the United States: U.S. Geological Hydrologic Atlas 730-M, 28 p., accessed April 21, 2021, at https://doi.org/10.3133/ha730M.

Ransom, K.M., 2019, Prediction of nitrate in groundwater at drinking-water well depths in the conterminous United States and potential applications for public health studies, in American Geophysical Union Fall Meeting, December 9-13, 2019, San Francisco, Calif.: American Geophysical Union abstract GH12A-07, accessed September 2, 2021, at https://agu.confex.com/agu/fm19/ meetingapp.cgi/Paper/616430.
Ransom, K.M., Nolan, B.T., Traum, J.A., Faunt, C.C., Bell, A.M., Gronberg, J.A.M., Wheeler, D.C., Rosecrans, C.Z., Jurgens, B., Schwarz, G.E., Belitz, K., Eberts, S.M., Kourakos, G., and Harter, T., 2017, A hybrid machine learning model to predict and visualize nitrate concentration throughout the Central Valley aquifer, California, USA: The Science of the Total Environment, v. 601-602, p. 1160-1172, accessed March 19, 2021, at https://doi.org/ 10.1016/j.scitotenv.2017.05.192.

Robson, S.G., and Banta, E.R., 1995, Arizona, Colorado, New Mexico, Utah, seg. 2 of Ground water atlas of the United States: U.S. Geological Survey Hydrologic Atlas 730-C, 32 p., accessed April 21, 2021, at https://doi.org/ 10.3133/ha730C.

Rosecrans, C.Z., Nolan, B.T., and Gronberg, J.A.M., 2017a, Predicted $\mathrm{pH}$ at the domestic and public supply drinking water depths, Central Valley, California: U.S. Geological Survey Scientific Investigations Map 3377, 1 sheet, scale 1:2,400,000, accessed April 21, 2021, at https://doi.org/ $10.3133 / \operatorname{sim} 3377$.

Rosecrans, C.Z., Nolan, B.T., and Gronberg, J.A.M., 2017b, Prediction and visualization of redox conditions in the groundwater of Central Valley, California: Journal of Hydrology (Amsterdam), v. 546, p. 341-356, accessed March 19, 2021, at https://doi.org/10.1016/j.jhydrol.2 017.01.014.

Rosecrans, C.Z., Nolan, B.T., and Gronberg, J.A.M., 2018, Maps showing predicted probabilities for selected dissolved oxygen and dissolved manganese threshold events in depth zones used by the domestic and public drinking water supply wells, Central Valley, California: U.S. Geological Survey Scientific Investigations Map 3397, 2 sheets, accessed April 21, 2021, at https://doi.org/10.3133/sim3397.

SciPy, 2020, scipy.stats.mannwhitneyu: SciPy, accessed July 23, 2020, at https://docs.scipy.org/doc/scipy/reference/ generated/scipy.stats.mannwhitneyu.html.

Soller, D.R., Reheis, M.C., Garrity, C.P., and Van Sistine, D.R., 2009, Map database for surficial materials in the conterminous United States: U.S. Geological Survey Data Series 425, scale 1:5,000,000, 12-p. pamphlet, accessed April 21, 2021, at https://doi.org/10.3133/ds425.

Stackelberg, P.E., Belitz, K., Brown, C.J., Erickson, M.L., Elliott, S.M., Kauffman, L.J., Ransom, K.M., and Reddy, J.E., 2021, Machine learning predictions of $\mathrm{pH}$ in the glacial aquifer system, northern USA: Ground Water, v. 59, no. 3, p. 352-368, accessed April 21, 2021, at https://doi.org/ 10.1111/gwat.13063. 
Stanton, J.S., Anning, D.W., Brown, C.J., Moore, R.B., McGuire, V.L., Qi, S.L., Harris, A.C., Dennehy, K.F., McMahon, P.B., Degnan, J.R., and Böhlke, J.K., 2017, Brackish groundwater in the United States: U.S. Geological Survey Professional Paper 1833, 185 p., accessed April 21, 2021, at https://doi.org/10.3133/pp1833.

U.S. Environmental Protection Agency, 2013, Safe drinking water information system (SDWIS) federal reporting services: U.S. Environmental Protection Agency web page, accessed April 19, 2021, at https://www.epa.gov/groundwater-and-drinking-water/safe-drinking-water-informationsystem-sdwis-federal-reporting.

U.S. Geological Survey, 2003, Ground water atlas of the United States: U.S. Geological Survey Hydrologic Atlas, v. 730, accessed April 21, 2021, at https://doi.org/ 10.3133/ha730.

U.S. Geological Survey, 2019, USGS water data for the nation: U.S. Geological Survey National Water Information System database, accessed April 21, 2021, at https://doi.org/ 10.5066/F7P55KJN.
Winston, R.B., and Ayotte, J.D., 2018, Performance assessments of a novel well design for reducing exposure to bedrock-derived arsenic: Ground Water, v. 56, no. 5, p. 762-769, accessed March 19, 2021, at https://doi.org/ 10.1111/gwat.12603.

Yager, R.M., Kauffman, L.J., Soller, D.R., Haj, A.E., Heisig, P.M., Buchwald, C.A., Westenbroek, S.M., and Reddy, J.E., 2018, Characterization and occurrence of confined and unconfined aquifers in Quaternary sediments in the glaciated conterminous United States: U.S. Geological Survey Scientific Investigations Report 2018-5091, 90 p., accessed April 21, 2021, at https://doi.org/10.3133/sir20185091.

Zekster, I., and Everett, L.G., 2004, Groundwater resources of the world and their use: Paris, France, United Nations Educational, Scientific and Cultural Organization, 346 p. 
Appendix 1. Hydrogeologic Settings in Principal Aquifers and Secondary Hydrogeologic Regions of the United States 


\section{A. Northeast}
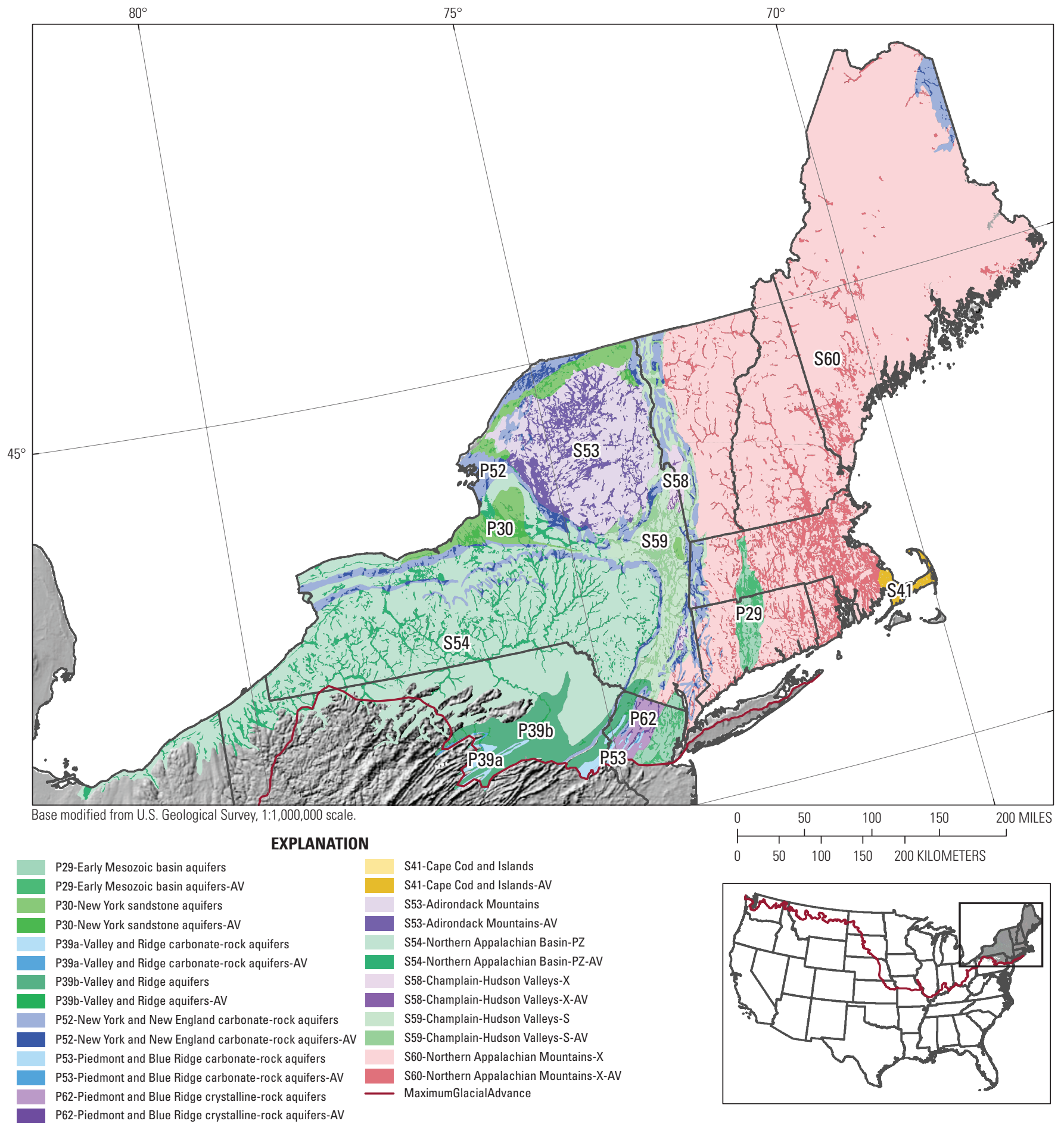

Figure 1.1. Maps showing the 288 hydrogeologic settings in the conterminous United States, by geographic area of the conterminous United States, in the $A$, Northeast; $B$, Eastern; $C$, Southeast; $D$, Central; $E$, Western Great Lakes; $F$, North Central; $G$, South Central; $H$, Southwest; and $I$, Northwest. The hydrogeologic settings are identified on the maps by a letter indicating if the hydrogeologic setting is a principal aquifer ("P") or a secondary hydrogeologic region ("S"). The numbers match those used in Belitz and others (2019) and Lovelace and others (2020). Abbreviations in the secondary hydrogeologic region names are as follows: K, Cretaceous; PZ, Paleozoic; Q, Quaternary; S, Sedimentary; T, Tertiary; V, volcanic; and X, crystalline. Hydrogeologic settings that have an "AV" suffix and lie north of the line of maximum glacial extent have coarse glacial overlying sediment; those hydrogeologic settings that lie to the south of the line of maximum glacial extent have alluvial valley overlying sediment. The hydrogeologic settings presented in the maps are also accessible as interactive searchable maps at https://doi.org/10.3133/sir20215069. 


\section{B. Mid-Atlantic}

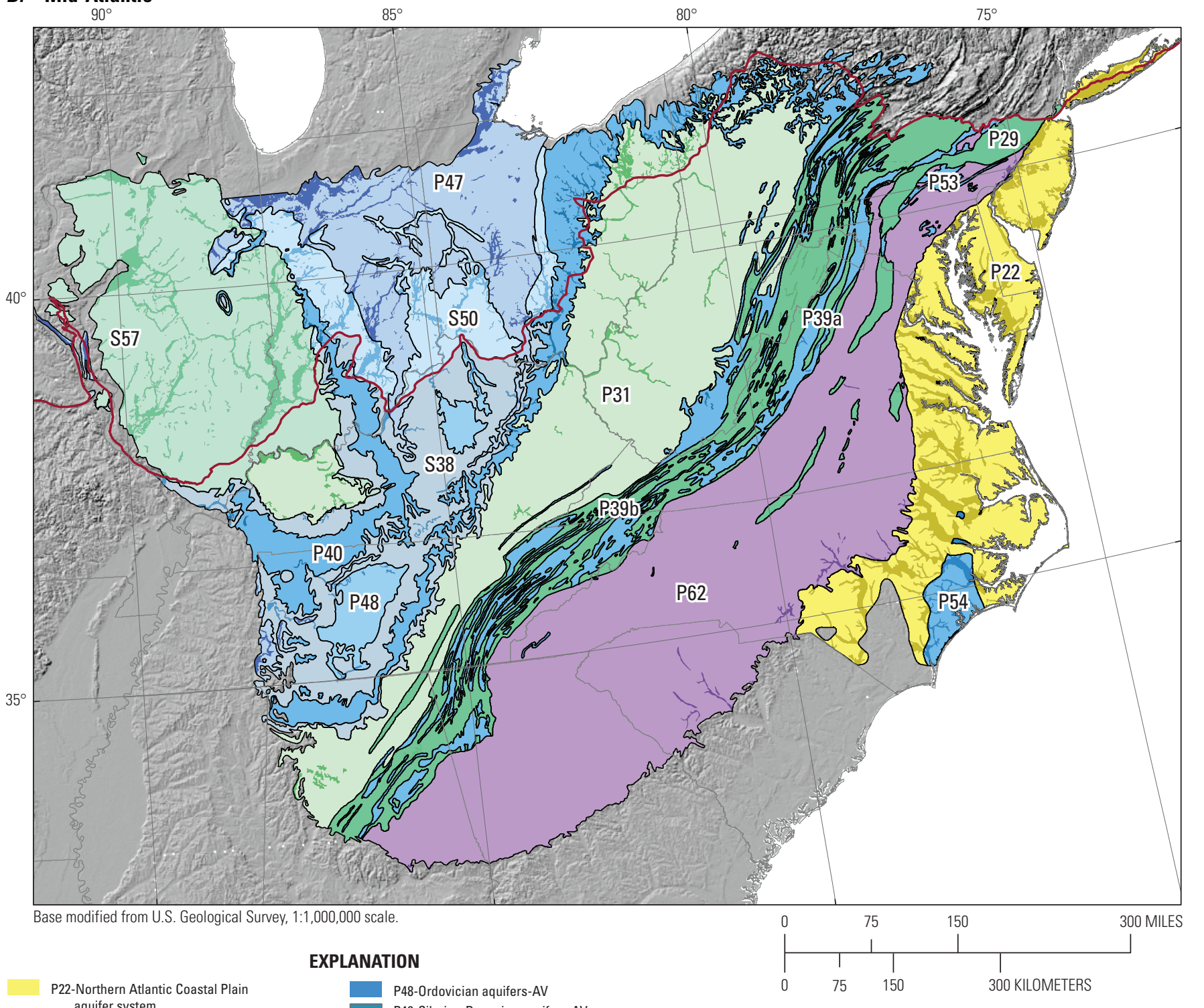
aquifer system

22-Northern Atlantic Coastal Plain aquifer system-AV

P28-Pennsylvanian aquifers-AV

P29-Early Mesozoic basin aquifers

P29-Early Mesozoic basin aquifers-AV

P31-Pennsylvanian aquifers

P31-Pennsylvanian aquifers-AV

P39a-Valley and Ridge carbonate-rock aquifers

P39a-Valley and Ridge carbonate-rock aquifers-AV

P39b-Valley and Ridge aquifers

P39b-Valley and Ridge aquifers-AV

P40-Mississippian aquifers

P40-Mississippian aquifers-AV

P47-Silurian-Devonian aquifers

P47-Silurian-Devonian aquifers-AV

P48-Ordovician aquifers

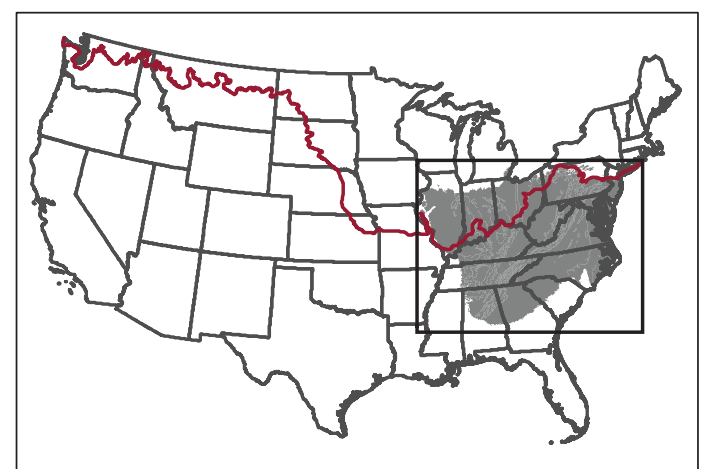

Figure 1.1.-Continued 


\section{Southeast}

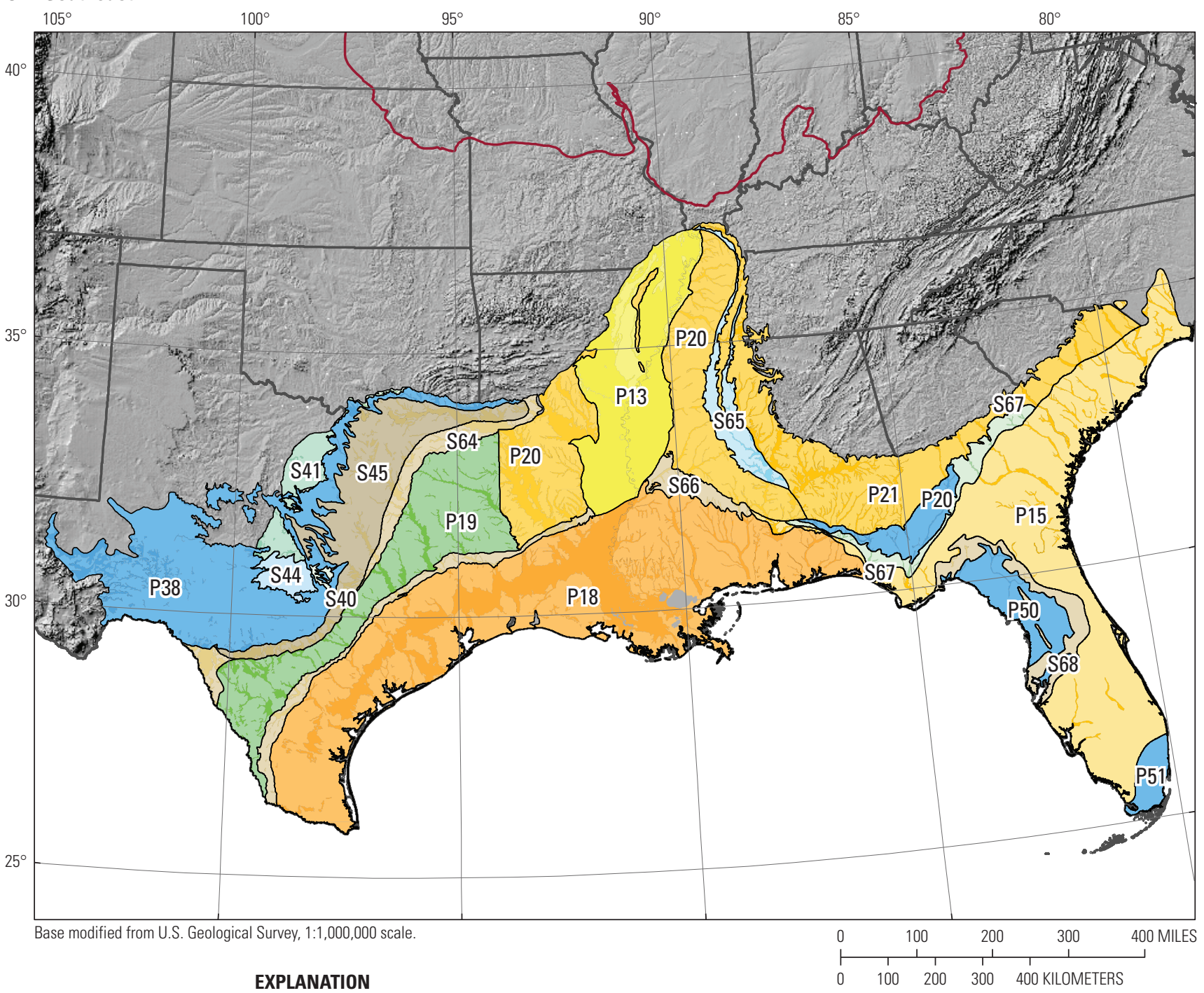

\footnotetext{
P13-Mississippi River Valley alluvial aquifer P13-Mississippi River Valley alluvial aquifer-AV

P15-Surficial aquifer system

- P15-Surficial aquifer system-AV

- P18-Coastal lowlands aquifer system

- P18-Coastal lowlands aquifer system-AV

- P19-Texas coastal uplands aquifer system

- P19-Texas coastal uplands aquifer system-AV

(-120-Mississippi embayment aquifer system

- P20-Mississippi embayment aquifer system-AV

P21-Southeastern Coastal Plain aquifer system

- P21-Southeastern Coastal Plain aquifer system-AV

- P38-Edwards-Trinity aquifer system

- P38-Edwards-Trinity aquifer system-AV

- P50-Floridan aquifer system

- P50-Floridan aquifer system-AV

- P51-Biscayne aquifer
}

S40-Texas-Cretaceous

- S40-Texas-Cretaceous-AV

- S41-Texas-Pennsylvanian

- S41-Texas-Pennsylvanian-AV

S44-Llano Uplift

- S45-Edwards-Trinity KT

- S45-Edwards-Trinity KT-AV

S64-Texas-KT

S64-Texas-KT-AV

S65-Mississippi Embayment-KT

- S65-Mississippi Embayment-KT-AV

S66-Gulf Coastal-T

- S66-Gulf Coastal-T-AV

S67-Southeast Coastal Plain-T

- S67-Southeast Coastal Plain-T-AV

S68-Florida-T

- S68-Florida-T-AV

- Maximum Glacial Advance

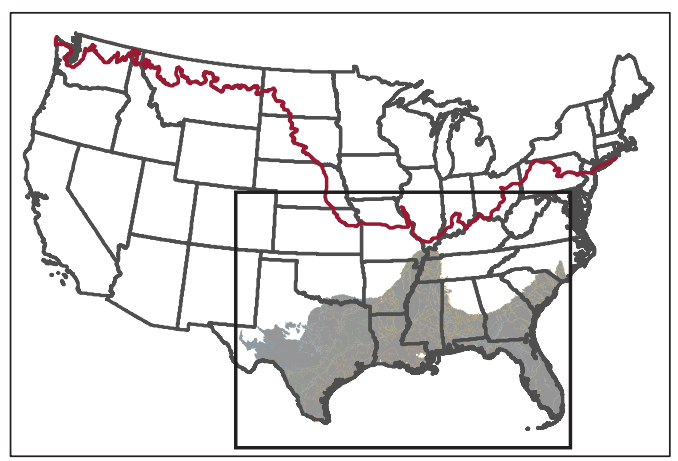

Figure 1.1.-Continued 


\section{Central}
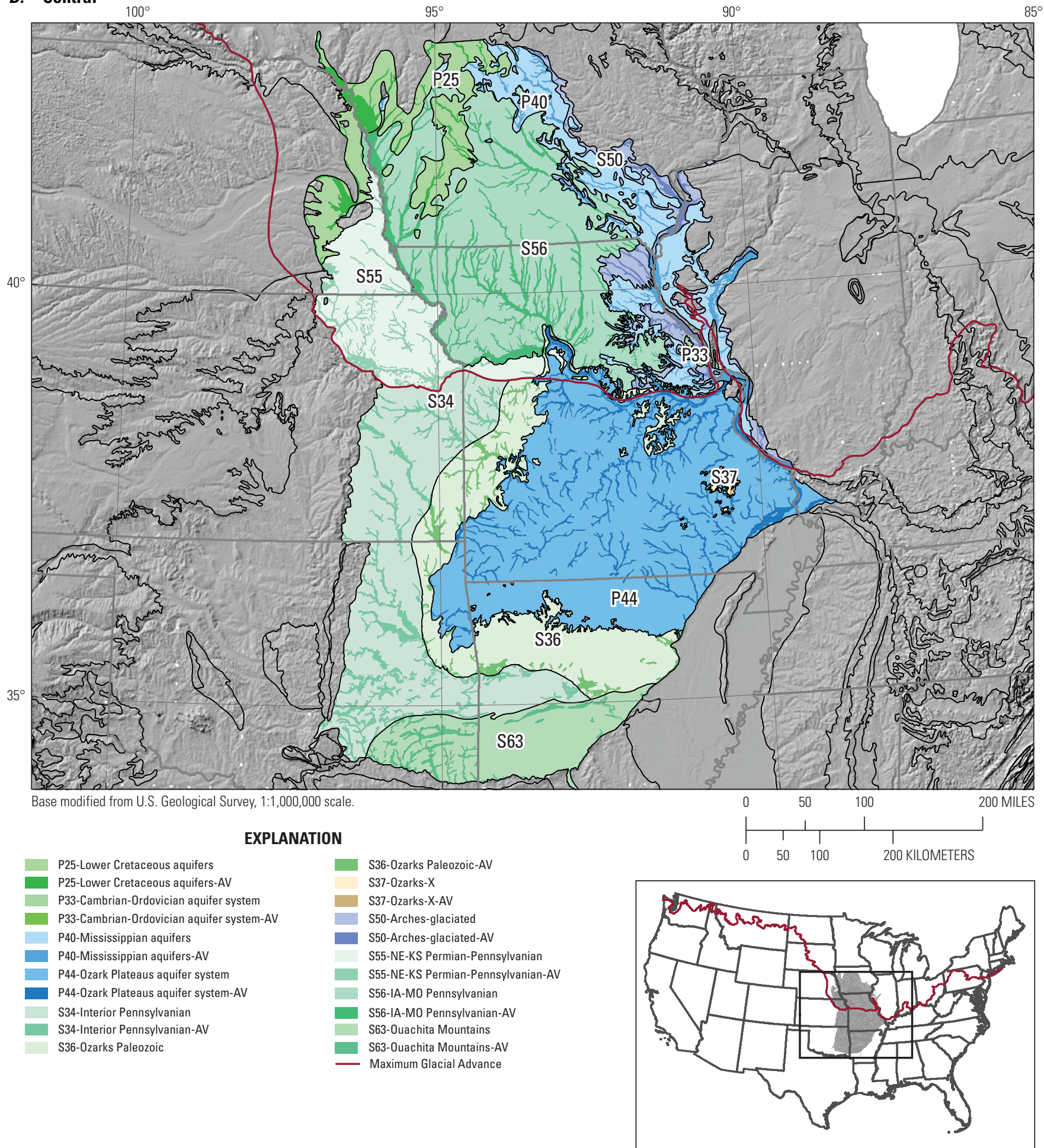

Figure 1.1.-Continued 


\section{E. Western Great Lakes}

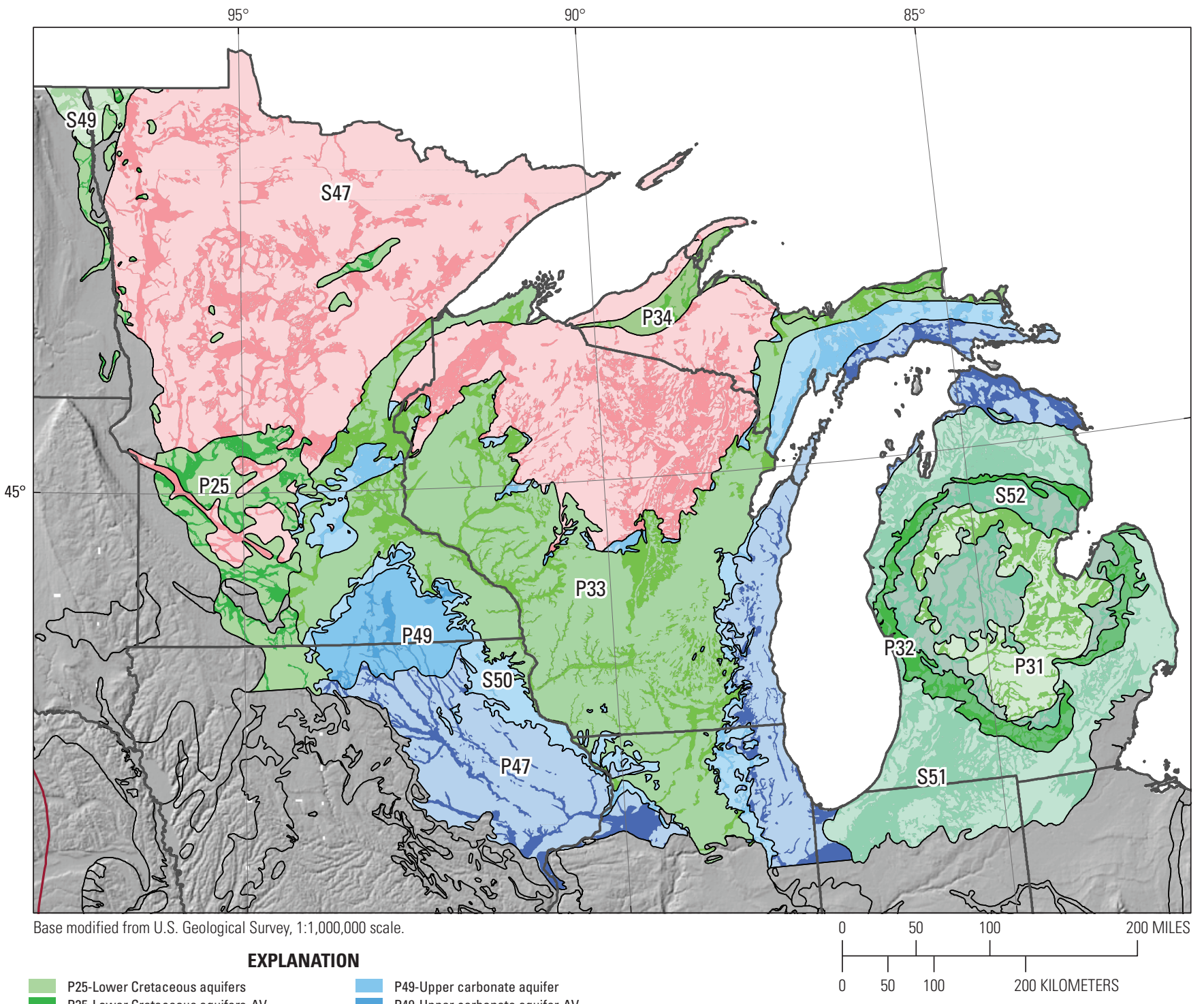

P25-Lower Cretaceous aquifers-AV

P31-Pennsylvanian aquifers

P31-Pennsylvanian aquifers-AV

P32-Marshall aquifer

P32-Marshall aquifer-AV

P33-Cambrian-Ordovician aquifer system

P33-Cambrian-Ordovician aquifer system-AV

P34-Jacobsville aquifer

P34-Jacobsville aquifer-AV

P47-Silurian-Devonian aquifers

P47-Silurian-Devonian aquifers-AV
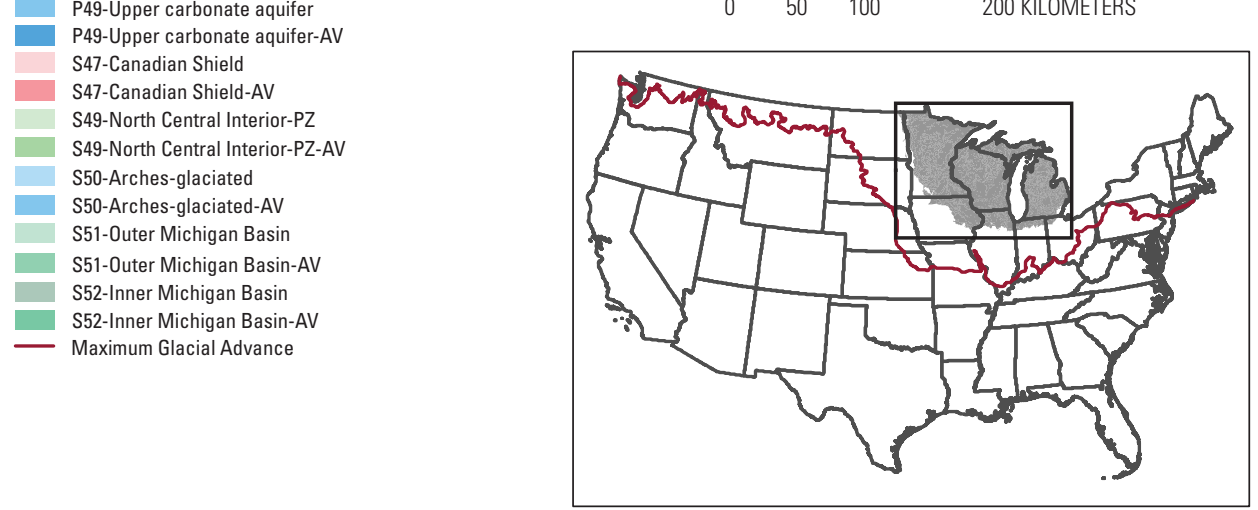

Figure 1.1.-Continued 


\section{F. North Central}

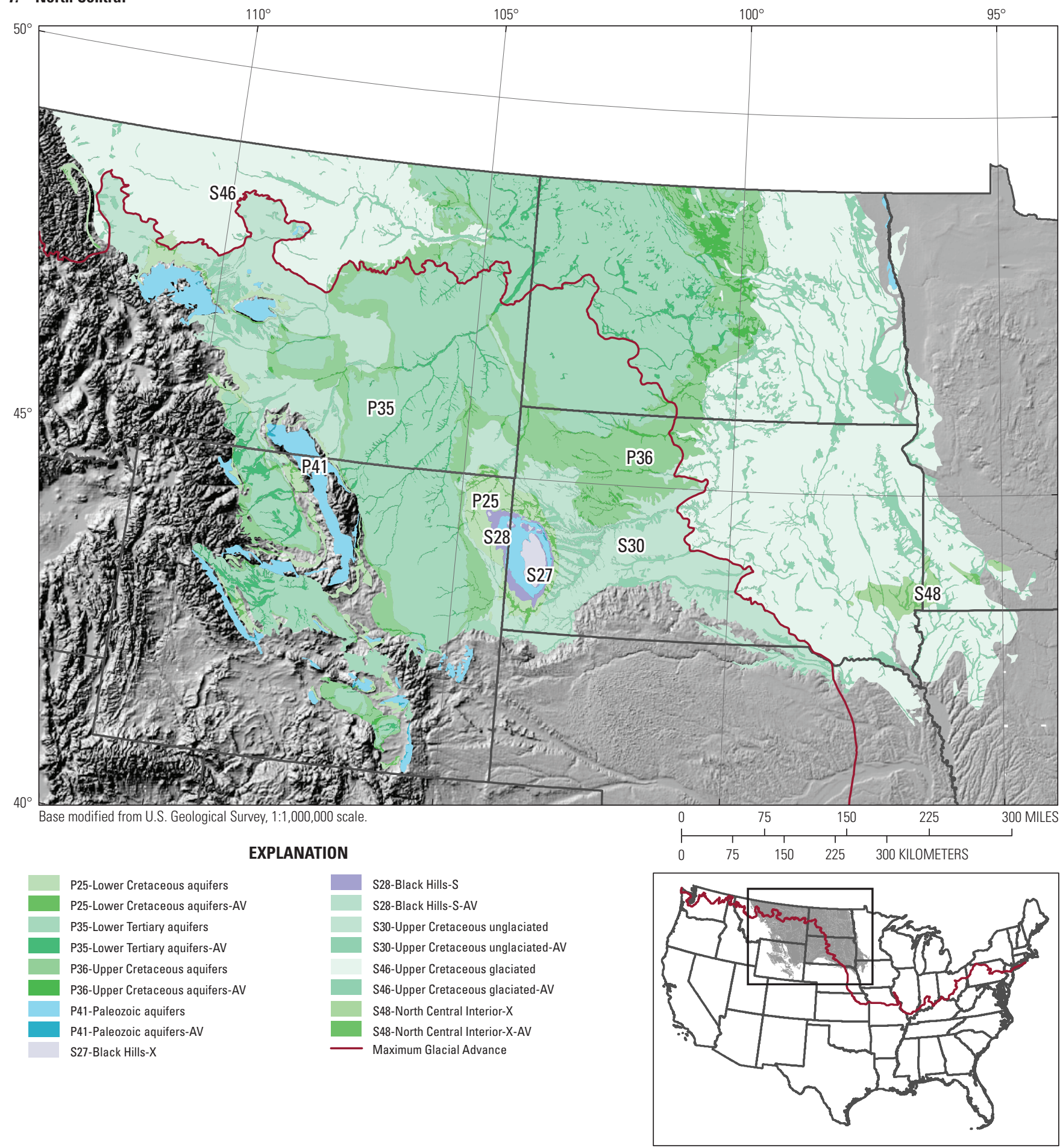

Figure 1.1.-Continued 
G. South Central

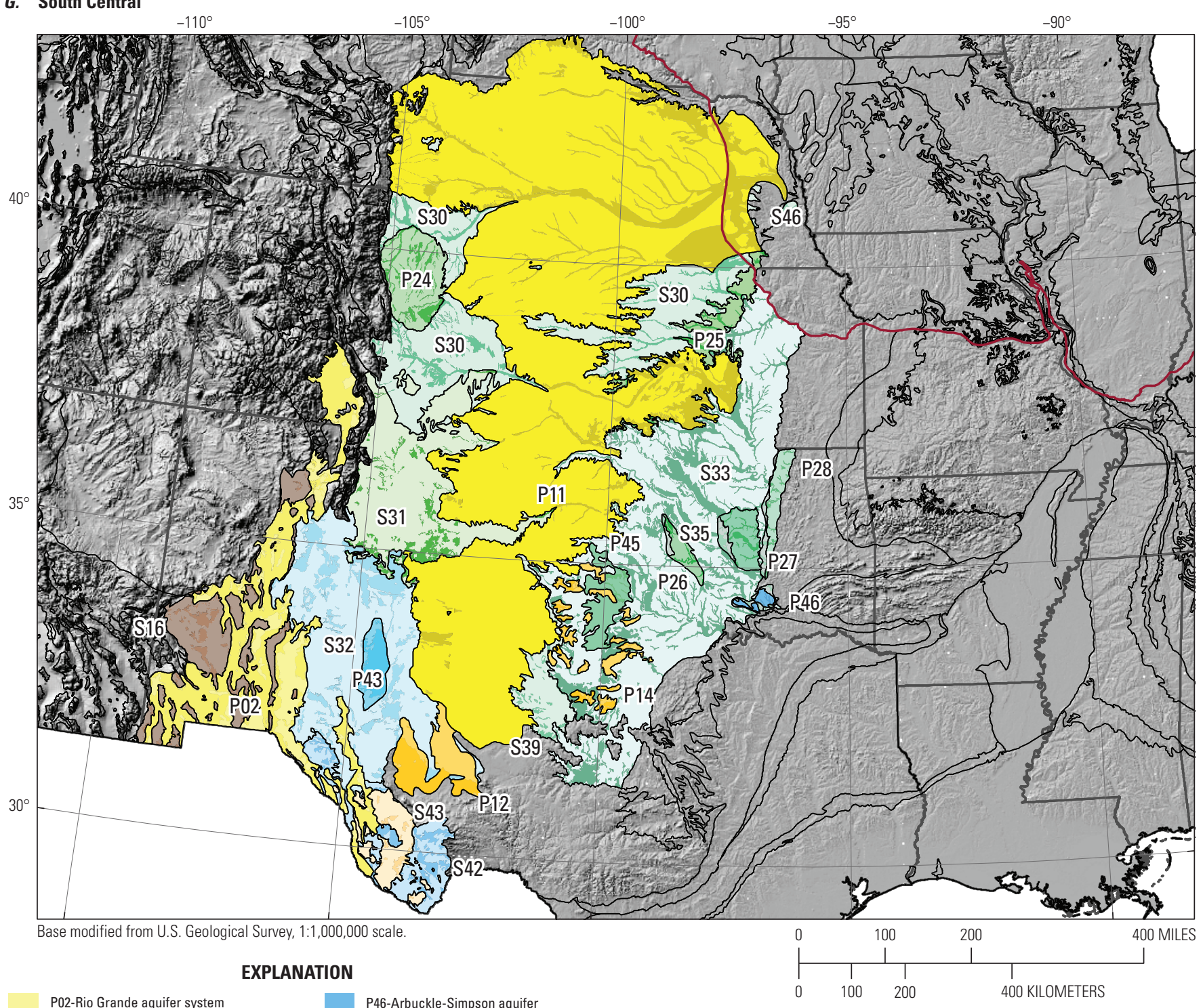

\begin{tabular}{|l}
\hline P02-Rio Grande aquifer system \\
P02-Rio Grande aquifer system-AV \\
P11-High Plains aquifer \\
P11-High Plains aquifer-AV \\
P12-Pecos River Basin alluvial aquifer \\
P12-Pecos River Basin alluvial aquifer-AV \\
P14-Seymour aquifer \\
P14-Seymour aquifer-AV \\
P24-Denver Basin aquifer system \\
P24-Denver Basin aquifer system-AV \\
P25-Lower Cretaceous aquifers \\
P25-Lower Cretaceous aquifers-AV \\
P26-Rush Springs aquifer \\
P26-Rush Springs aquifer-AV \\
P27-Central Oklahoma aquifer \\
P27-Central Oklahoma aquifer-AV \\
P28-Ada-Vamoosa aquifer \\
P28-Ada-Vamoosa aquifer-AV \\
P43-Roswell Basin aquifer system \\
P43-Roswell Basin aquifer system-AV \\
P45-Blaine aquifer \\
P45-Blaine aquifer-AV
\end{tabular}

P46-Arbuckle-Simpson aquifer

P46-Arbuckle-Simpson aquifer-AV S16-Rio Grande Highlands S16-Rio Grande Highlands-AV S30-Upper Cretaceous unglaciated

S30-Upper Cretaceous unglaciated-AV S31-Raton Basin

S31-Raton Basin-AV S32-Eastern New Mexico S32-Eastern New Mexico-AV S33-Interior Permian

S33-Interior Permian-AV

S35-OK Permian-Pennsylvanian

S35-OK Permian-Pennsylvanian-AV S39-Texas-Triassic S39-Texas-Triassic-AV S42-West Texas-S S42-West Texas-S-AV S43-West Texas-V

S43-West Texas-V-AV

S46-Upper Cretaceous glaciated

S46-Upper Cretaceous glaciated-AV Maximum Glacial Advance

Figure 1.1.-Continued 
H. Southwest

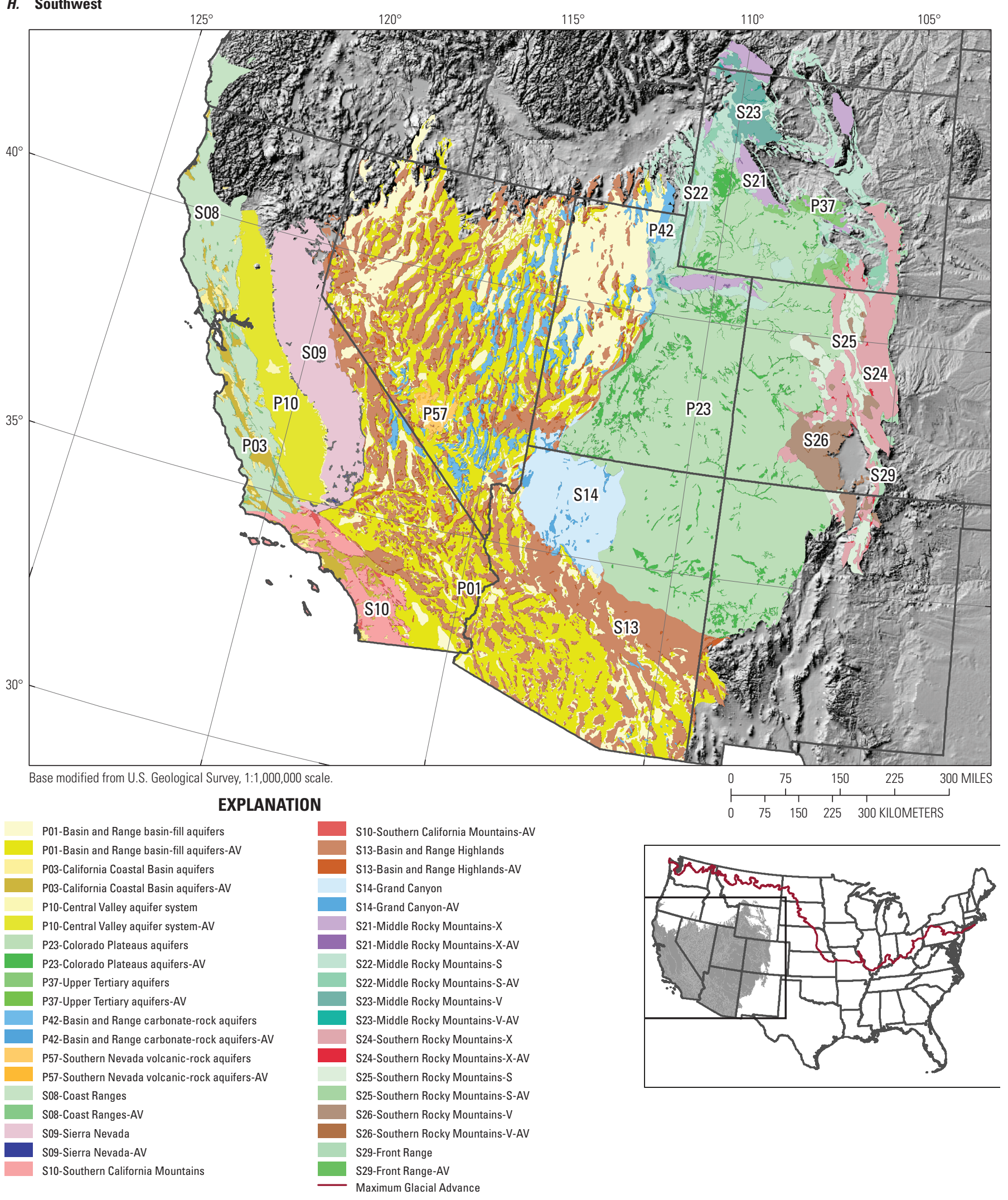

Figure 1.1.-Continued 


\section{Northwest}
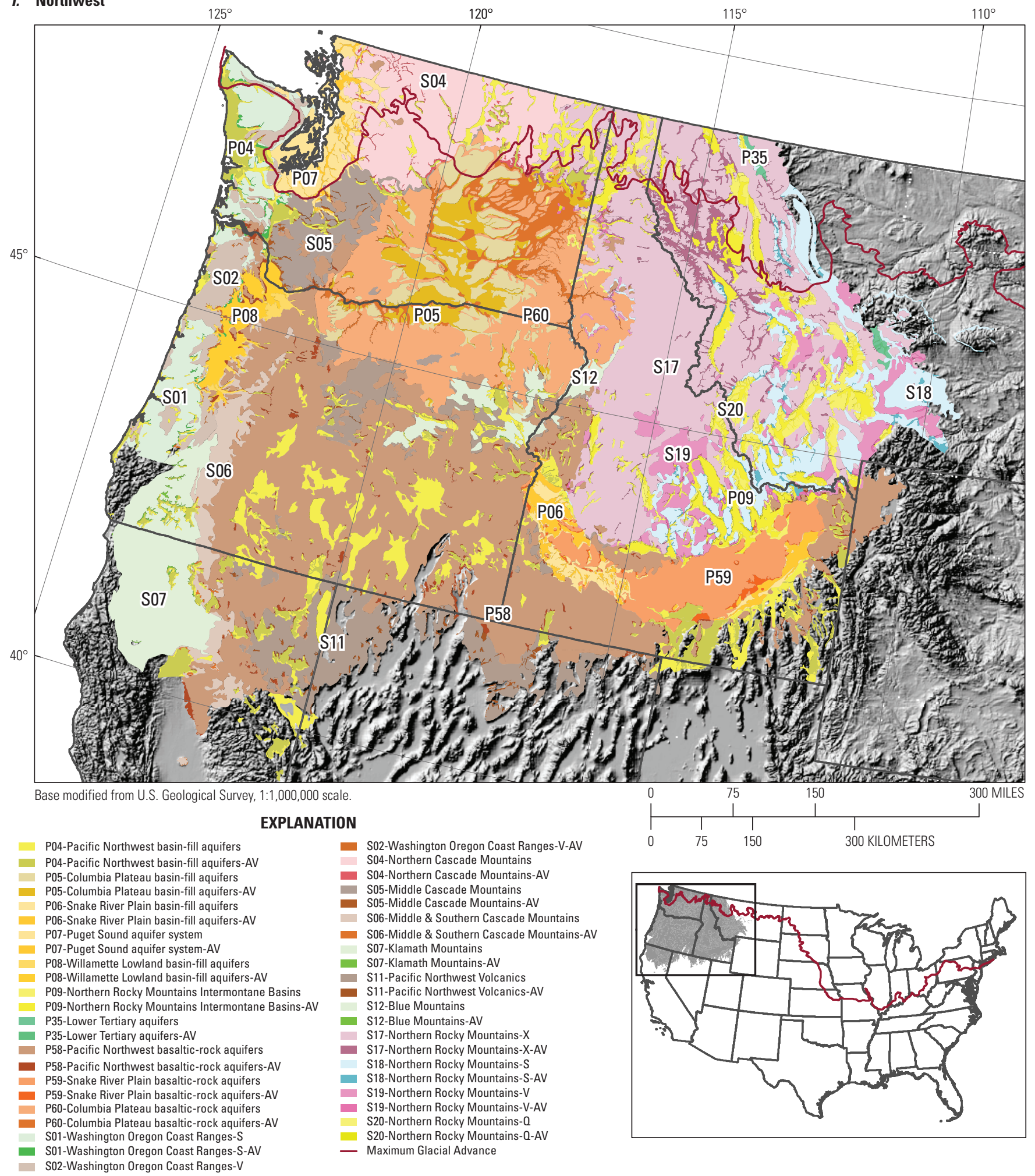
S02-Washington Oregon Coast Ranges-V-AV S04-Northern Cascade Mountains
- S04-Northern Cascade Mountains-AV
- S05-Middle Cascade Mountains
- S05-Middle Cascade Mountains-AV
- S06-Middle \& Southern Cascade Mountains
- S06-Middle \& Southern Cascade Mountains-AV S07-Klamath Mountains
- S07-Klamath Mountains-AV
- S11-Pacific Northwest Volcanics
- S11-Pacific Northwest Volcanics-AV S12-Blue Mountains
S12-Blue Mountains-AV
S17-Northern Rocky Mountains-X
S17-Northern Rocky Mountains-X-AV S18-Northern Rocky Mountains-S
S18-Northern Rocky Mountains-S-AV
S19-Northern Rocky Mountains-V
S19-Northern Rocky Mountains-V-AV S20-Northern Rocky Mountains-0
S20-Northern Rocky Mountains-0-AV
- Maximum Glacial Advance

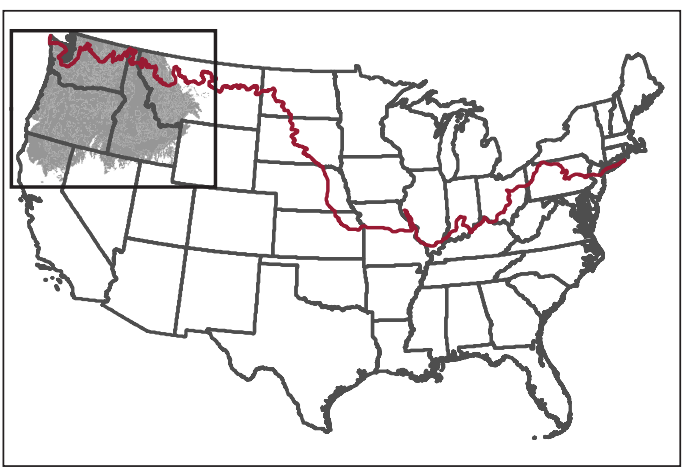

Figure 1.1.-Continued 


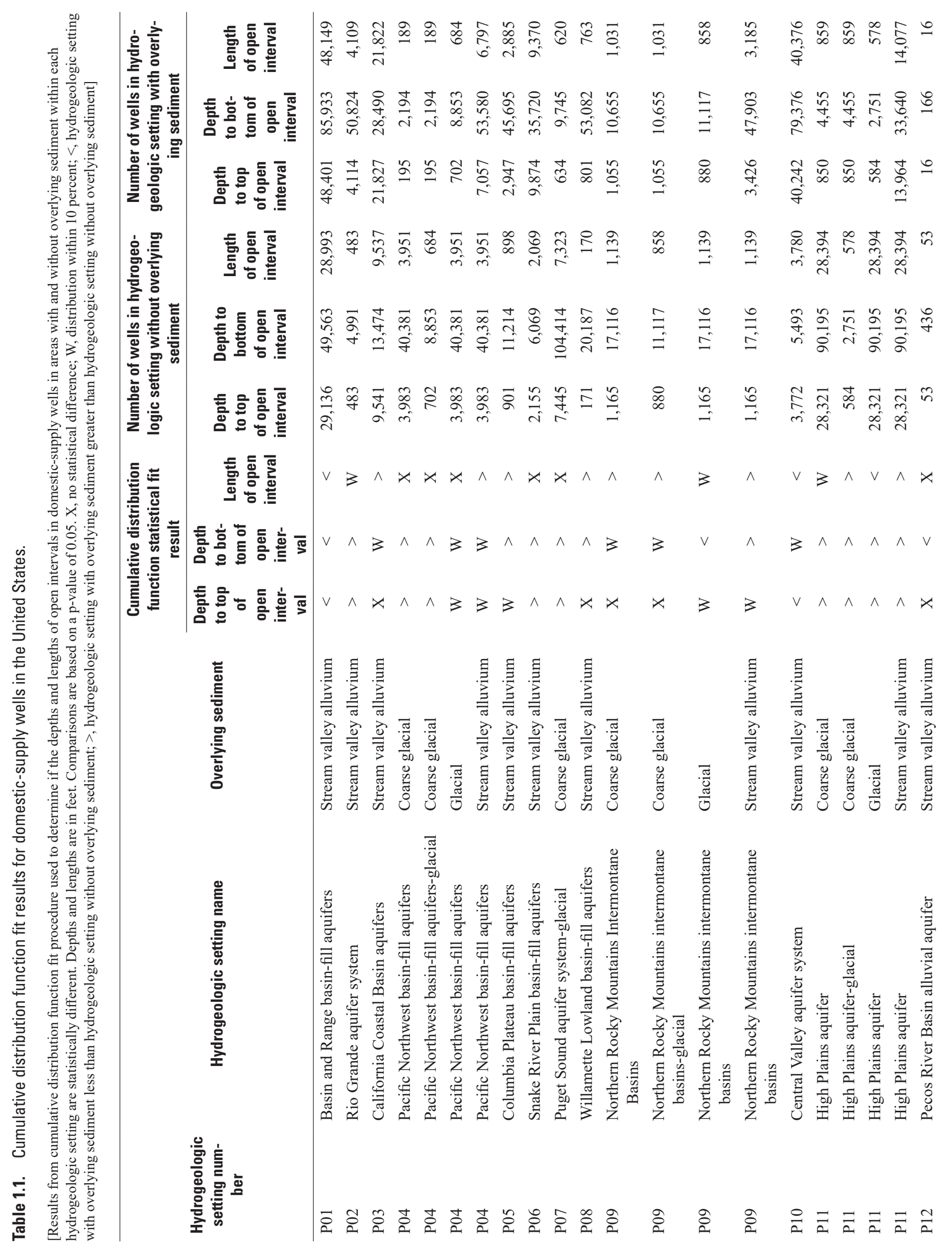




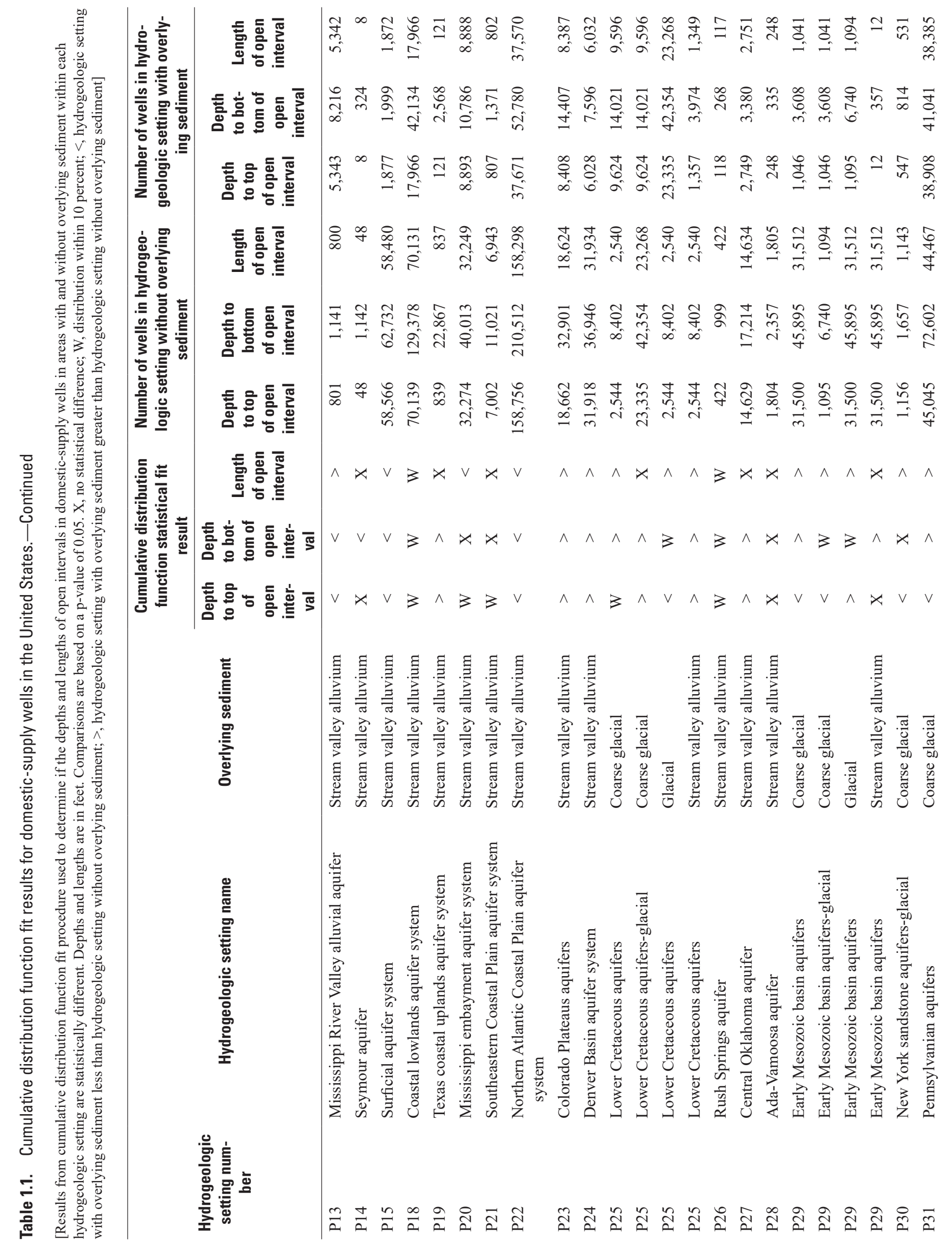




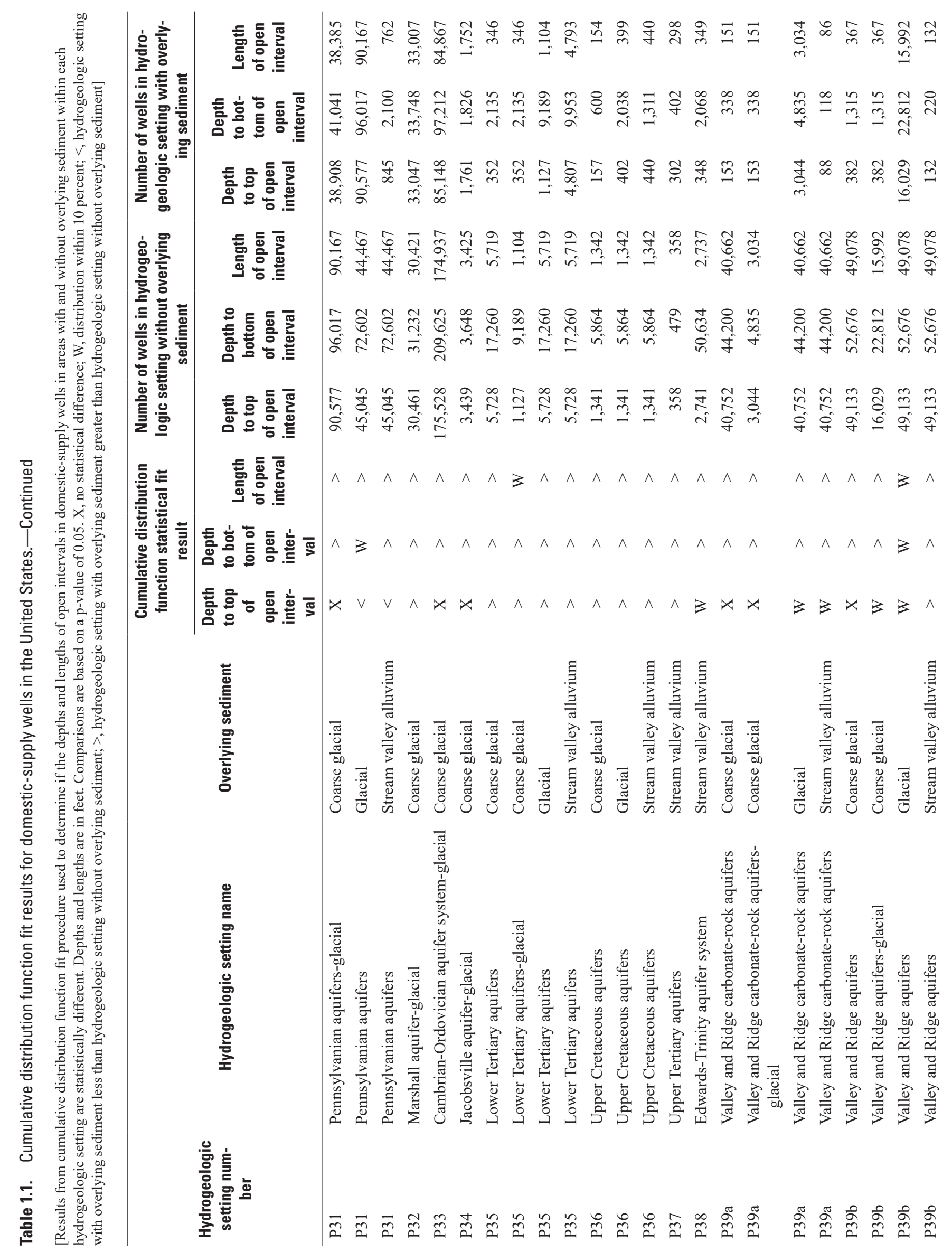




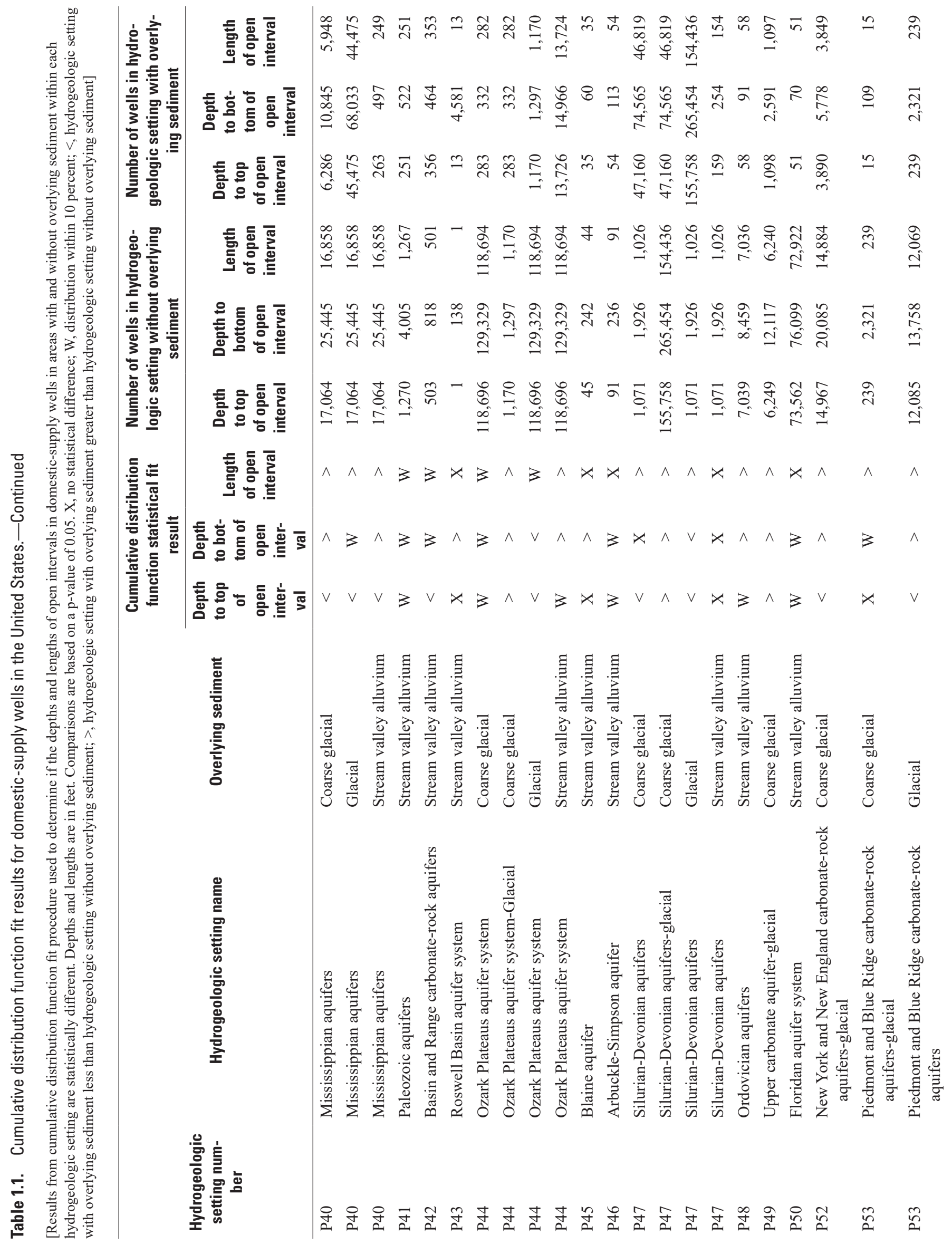




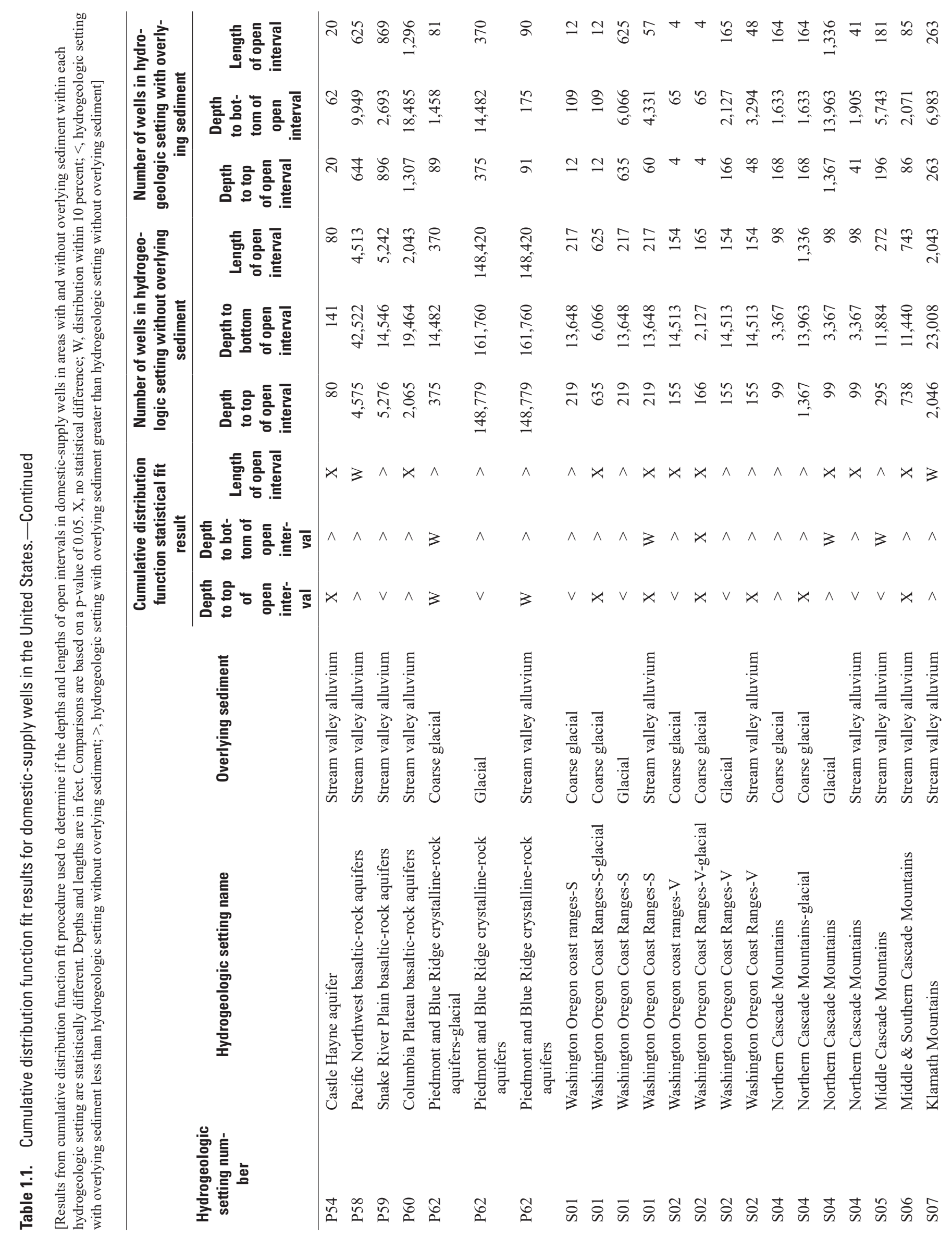




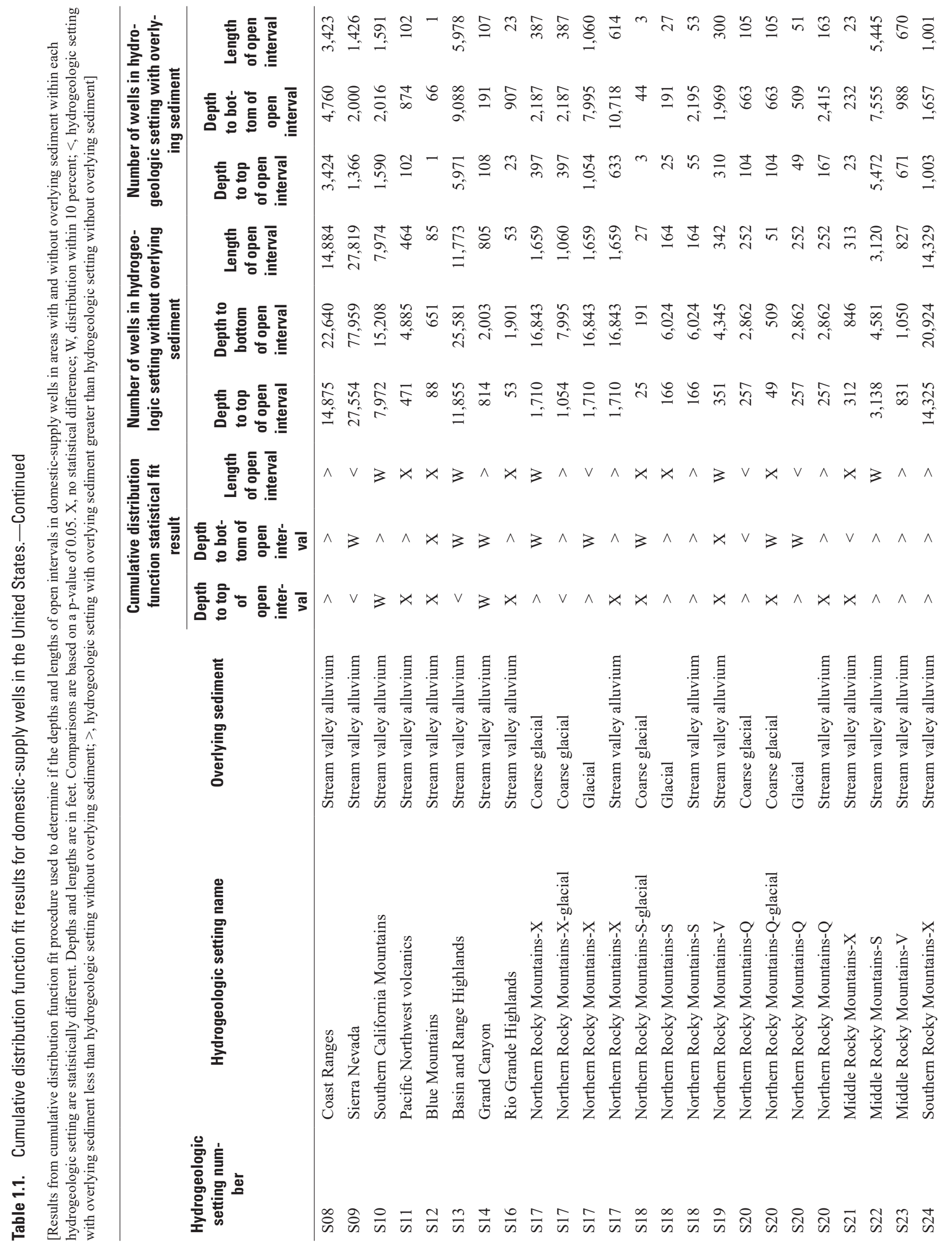




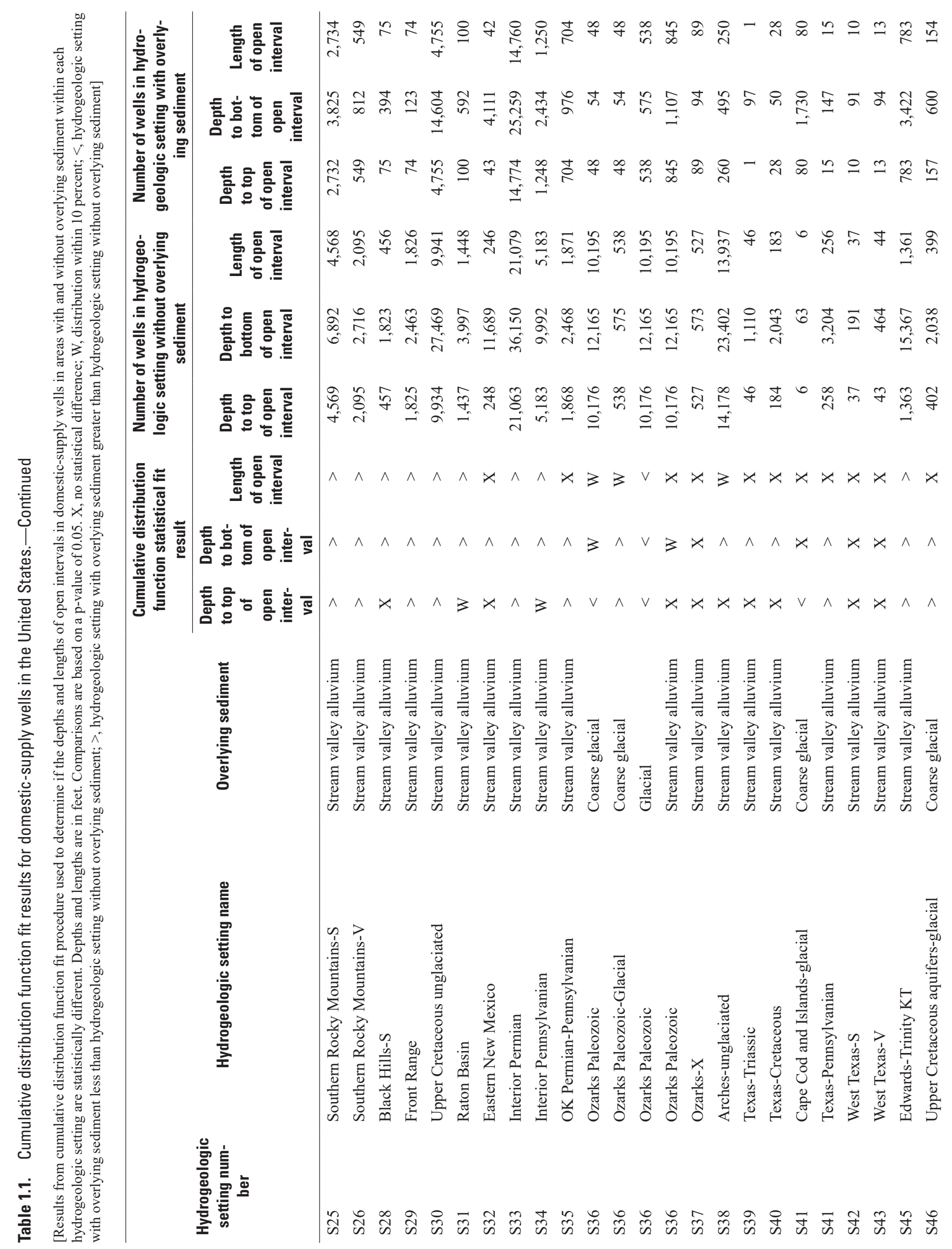




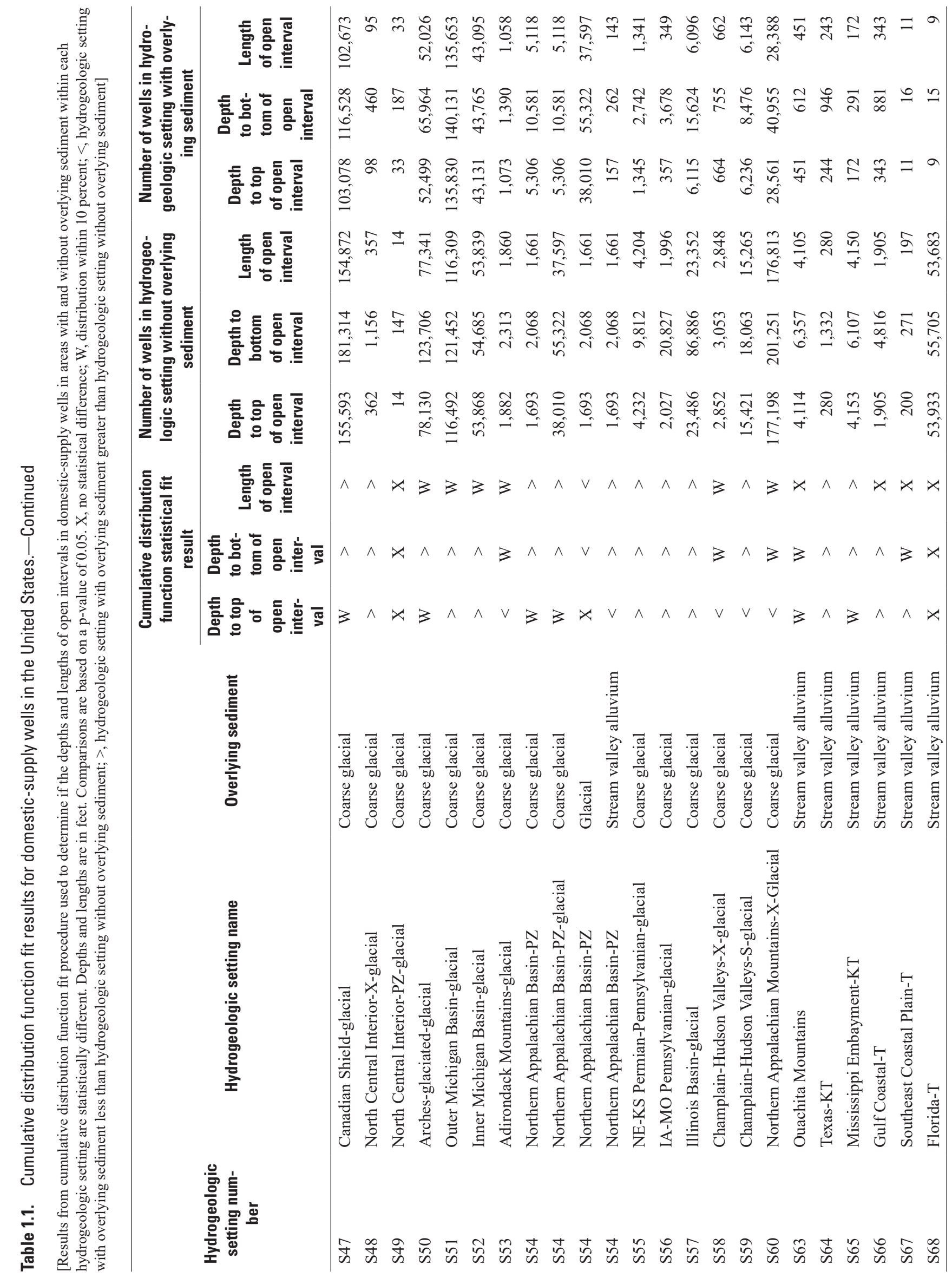




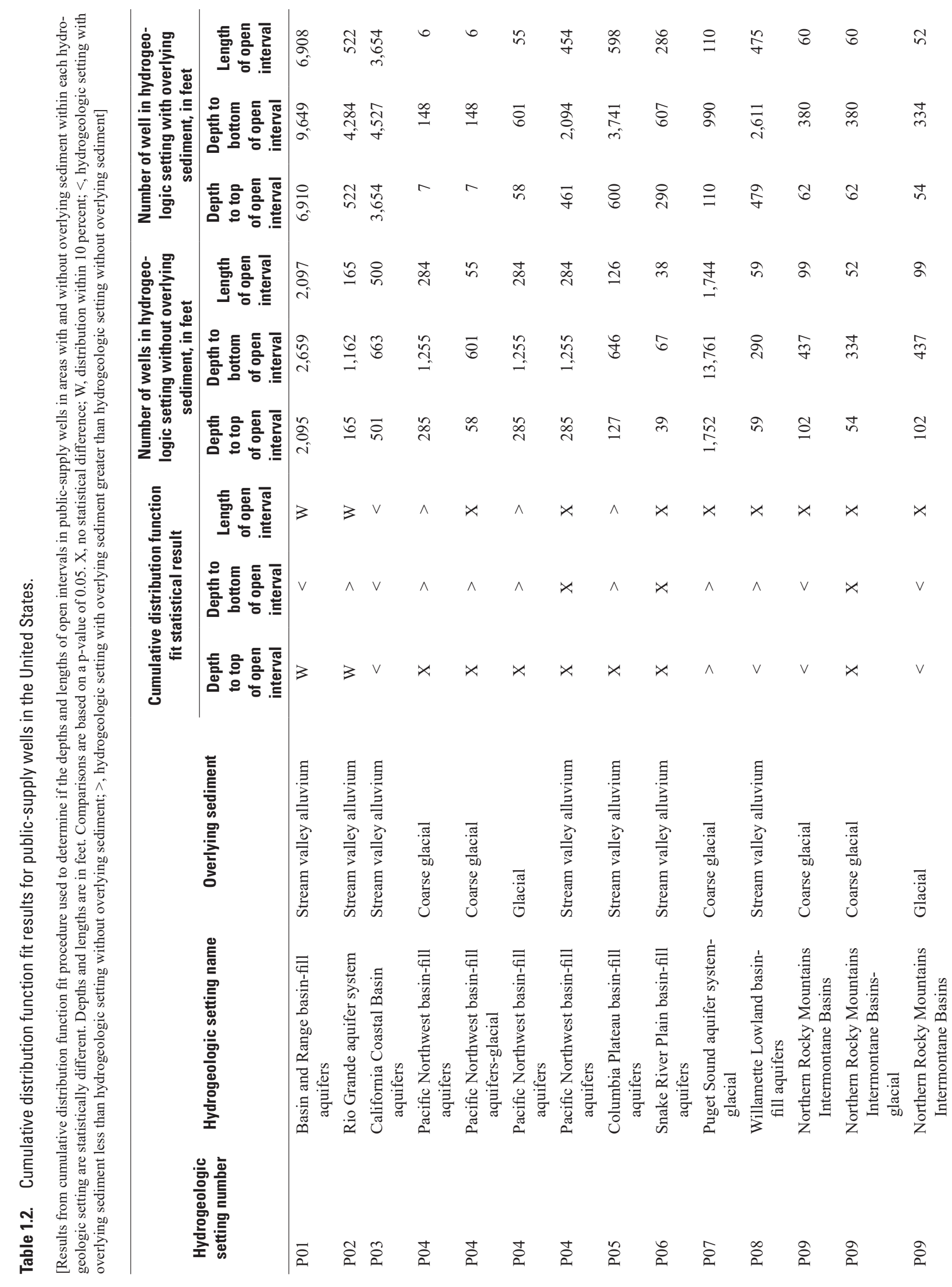




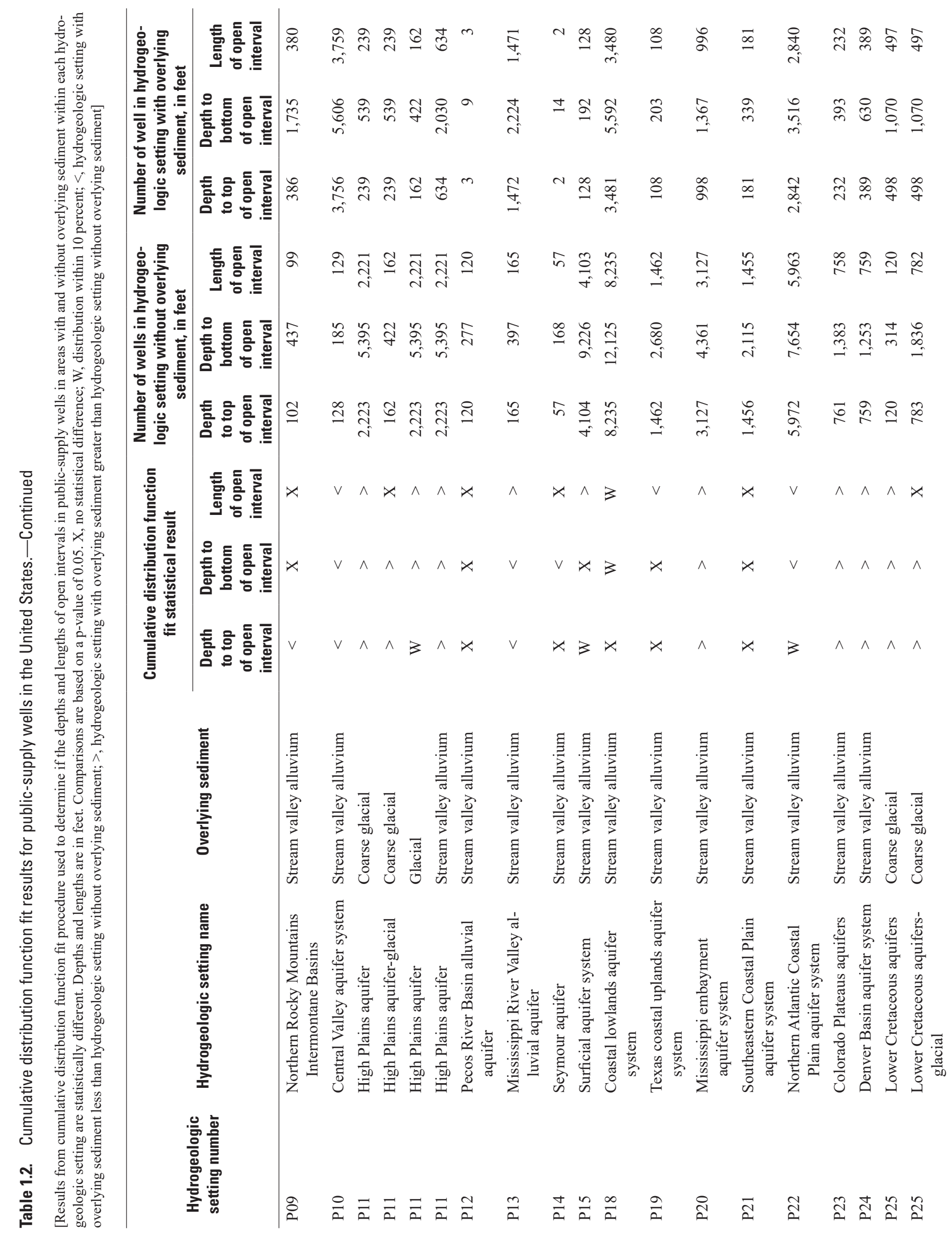




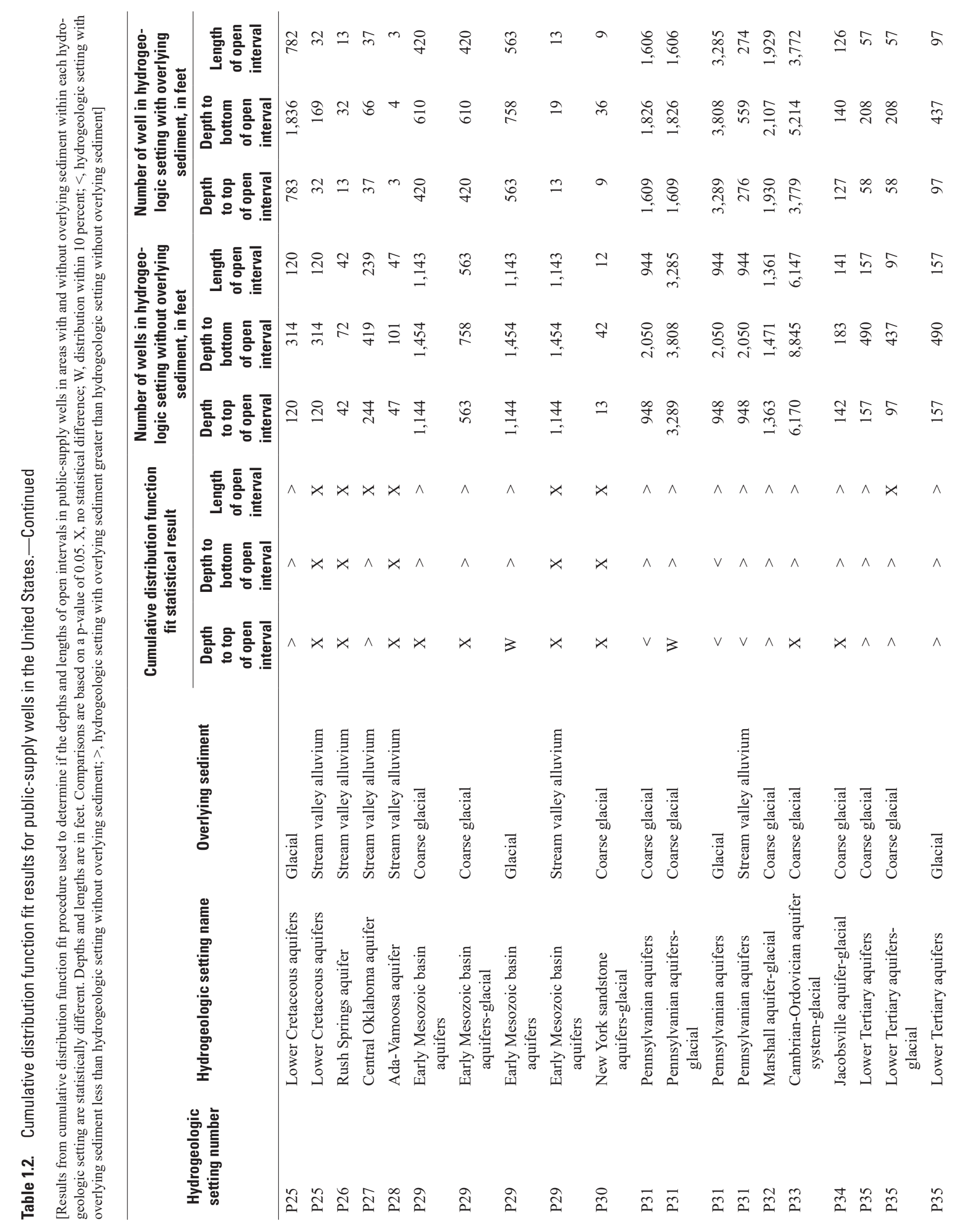




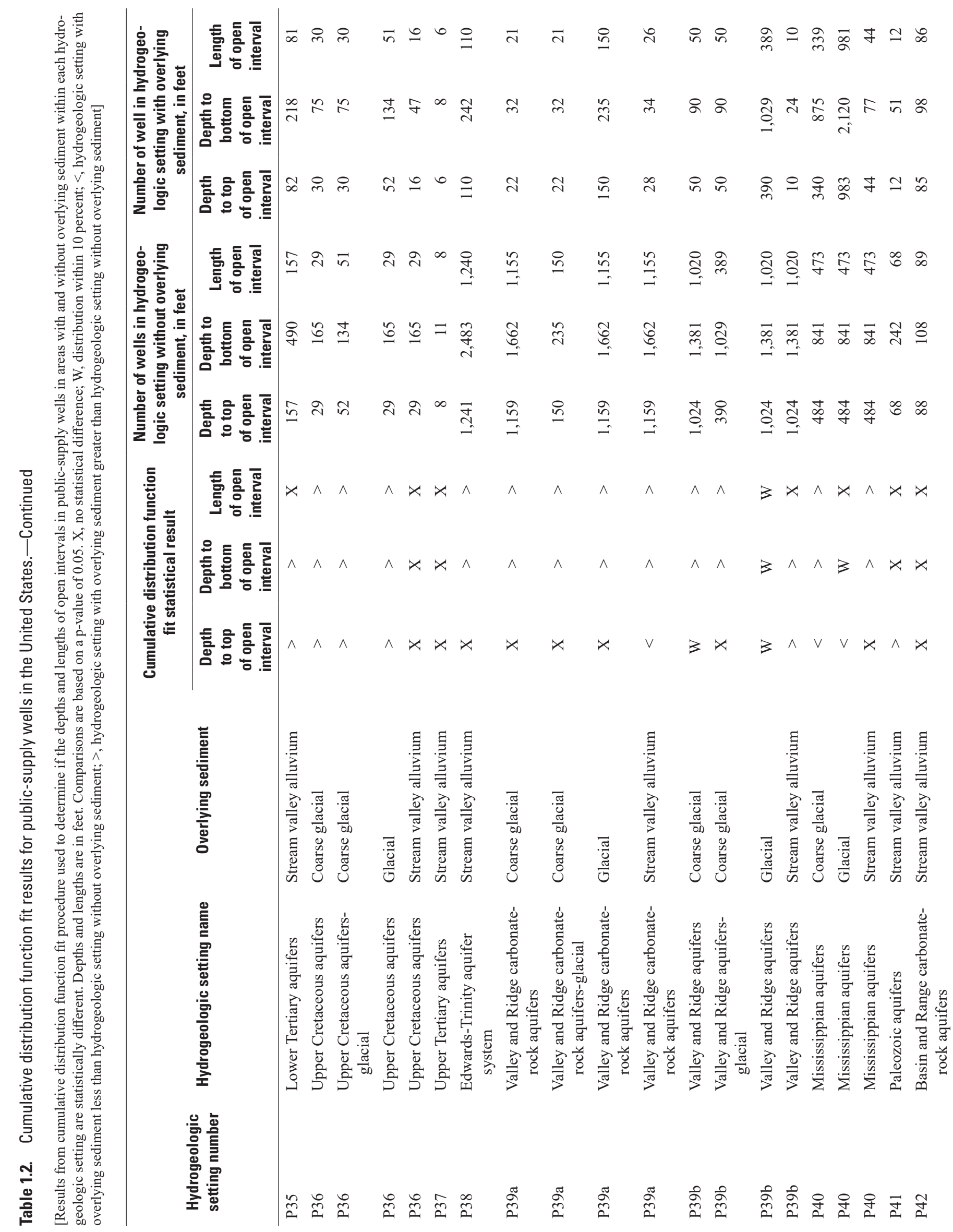




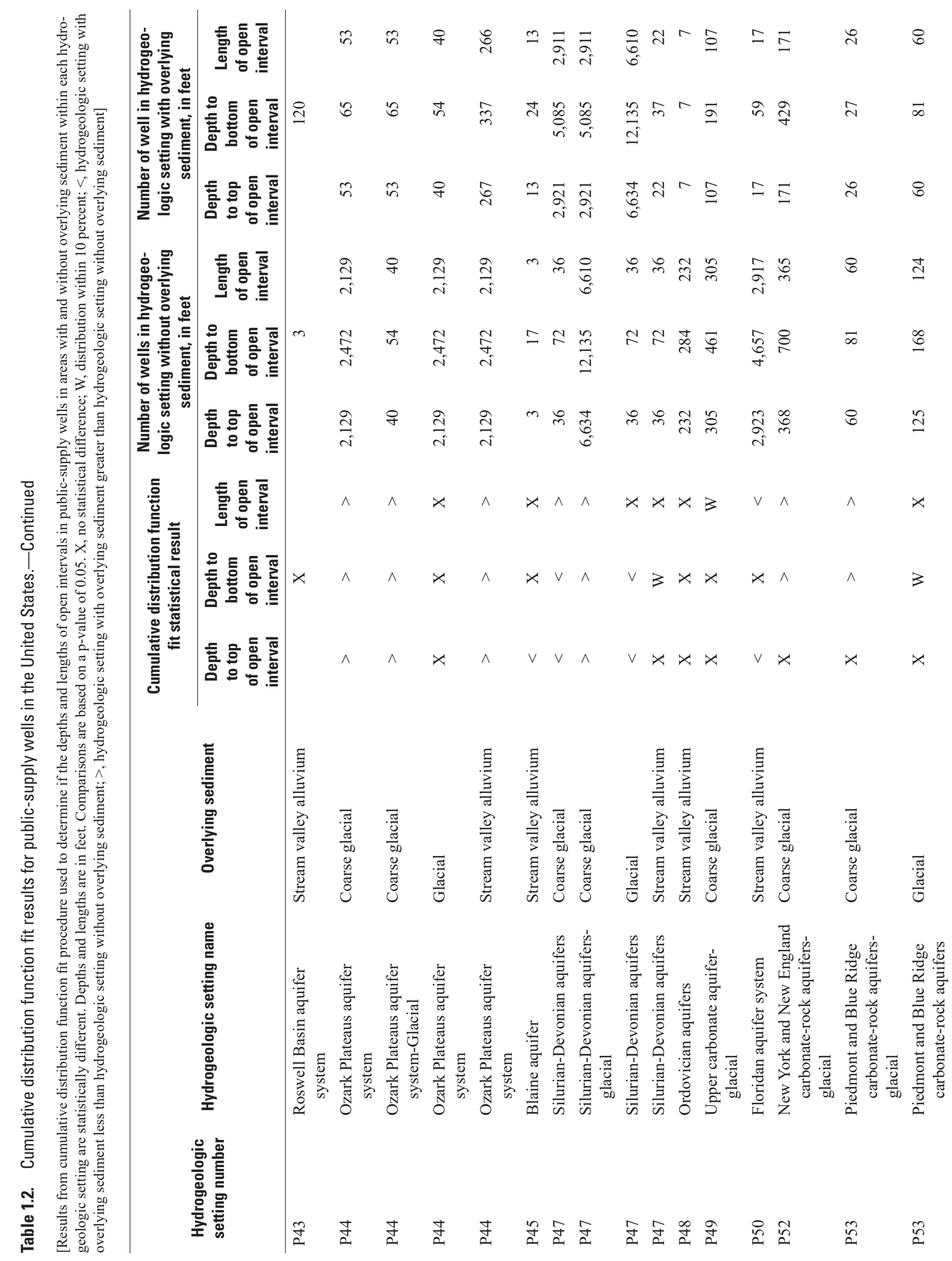




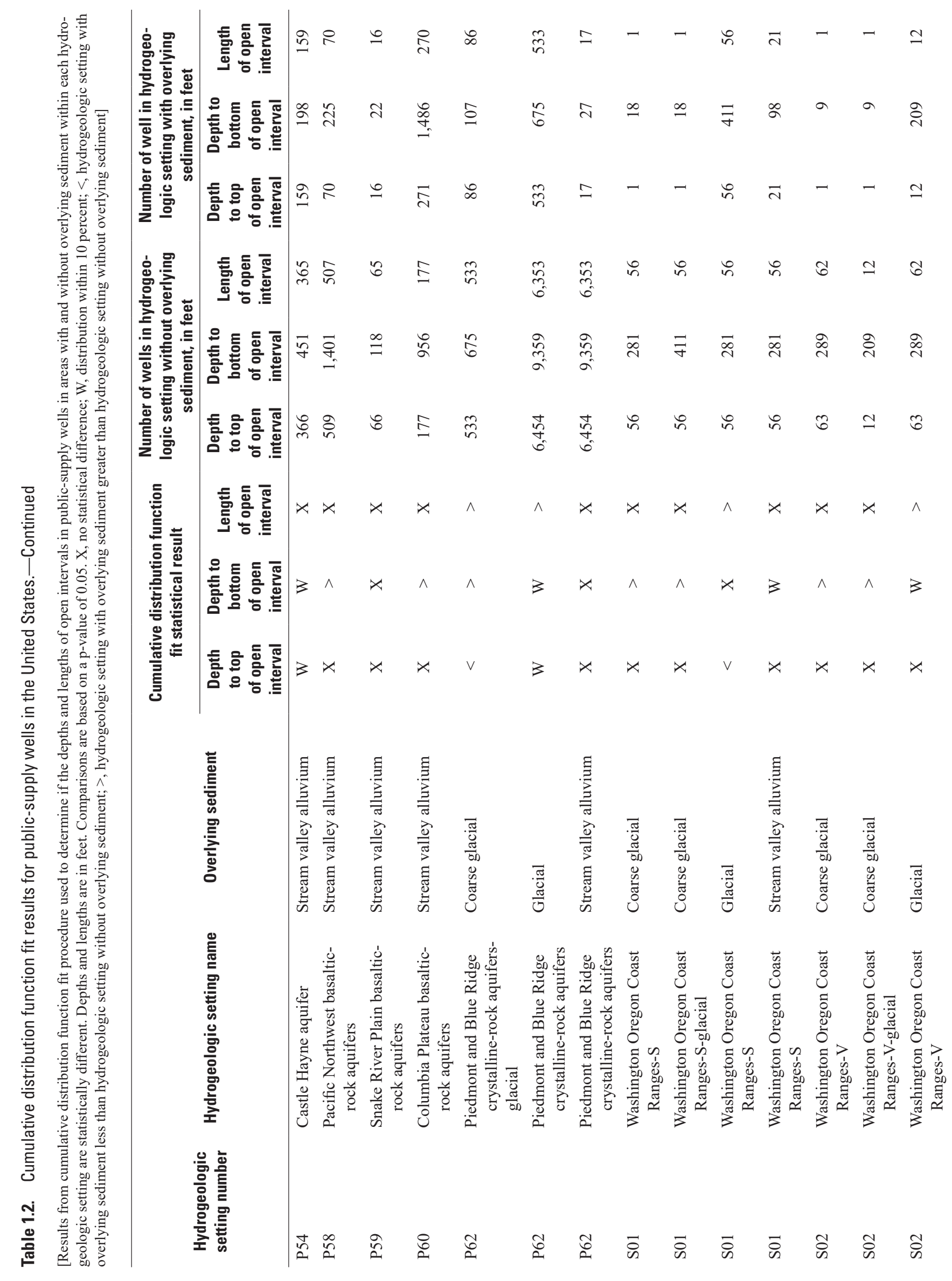




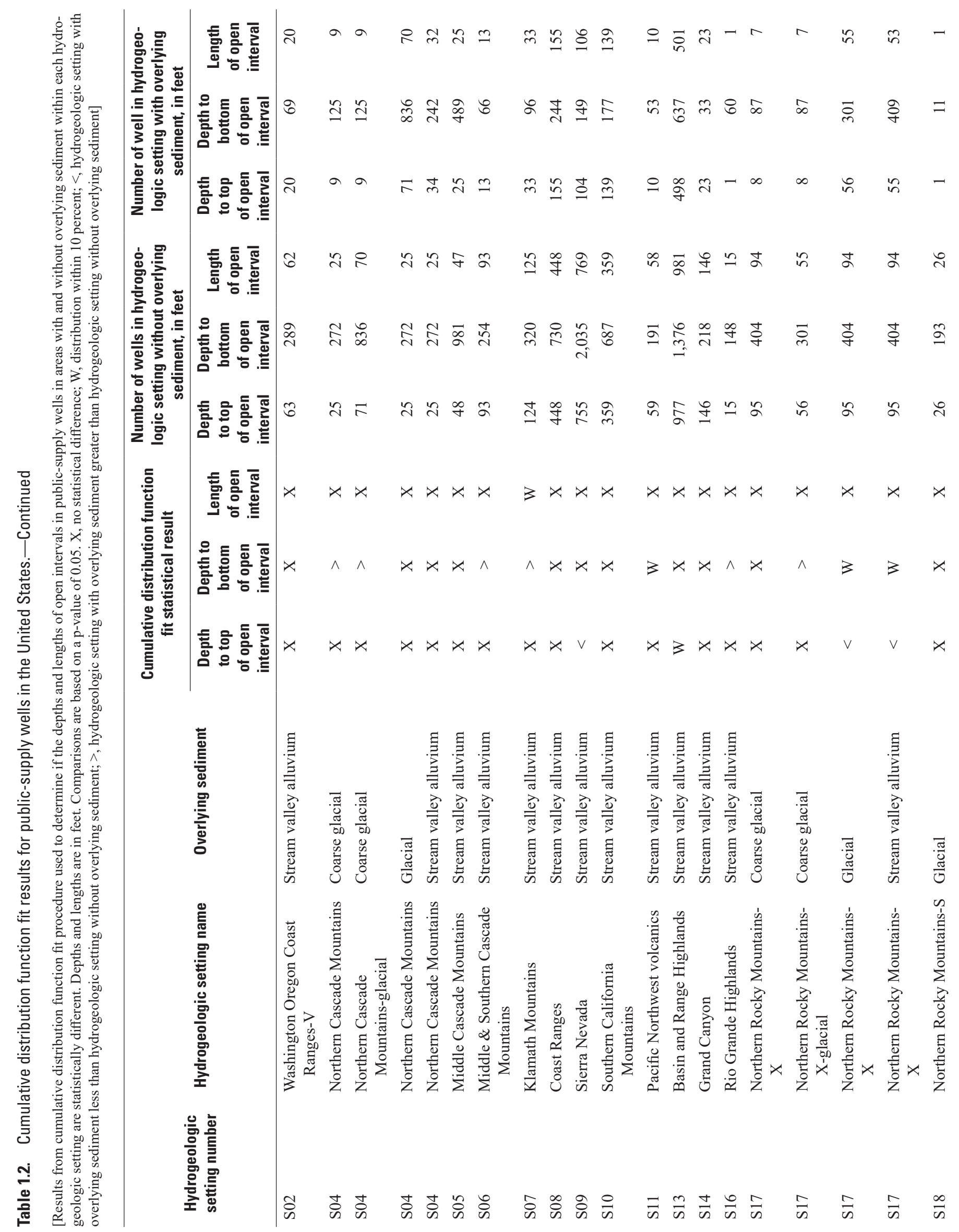




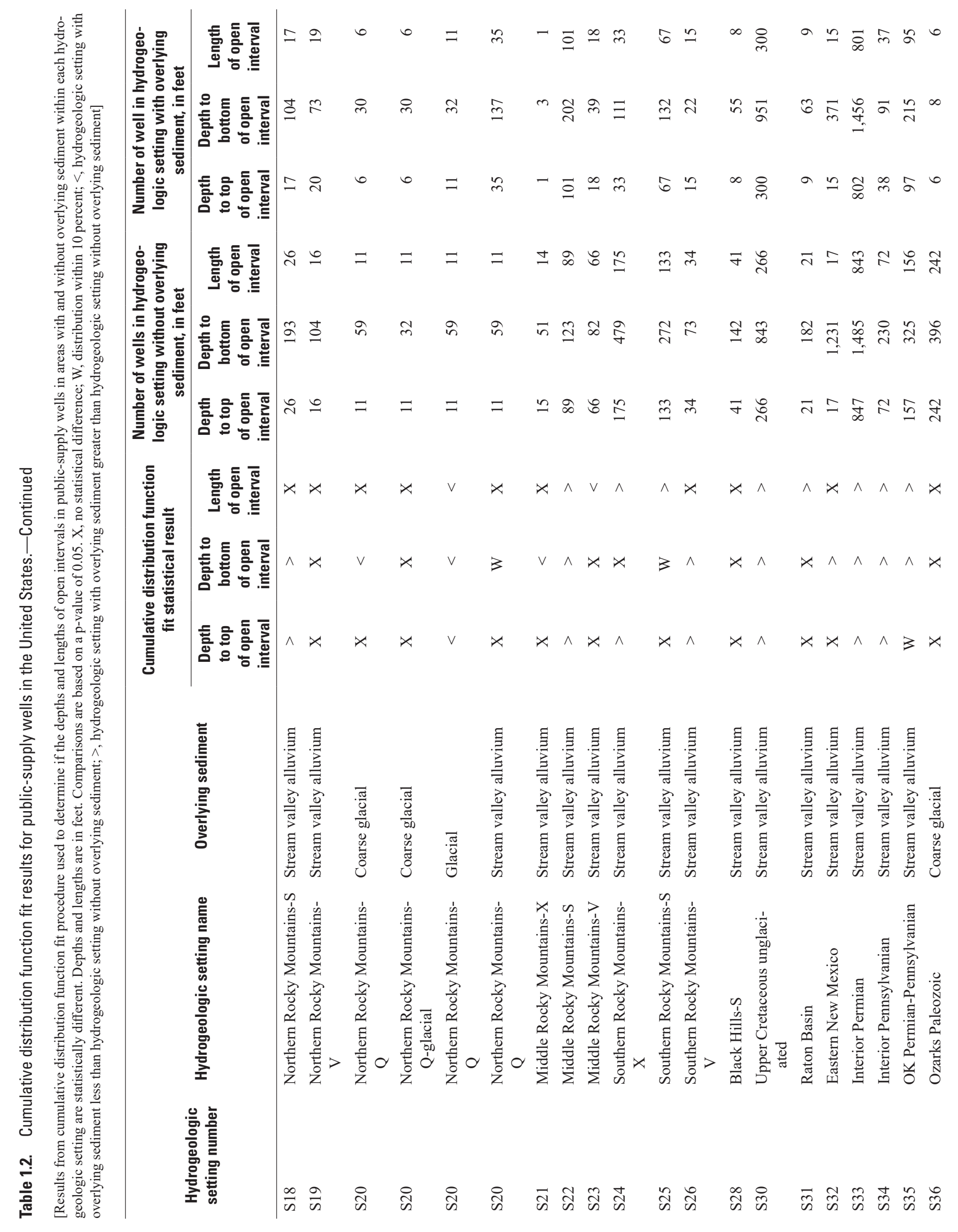




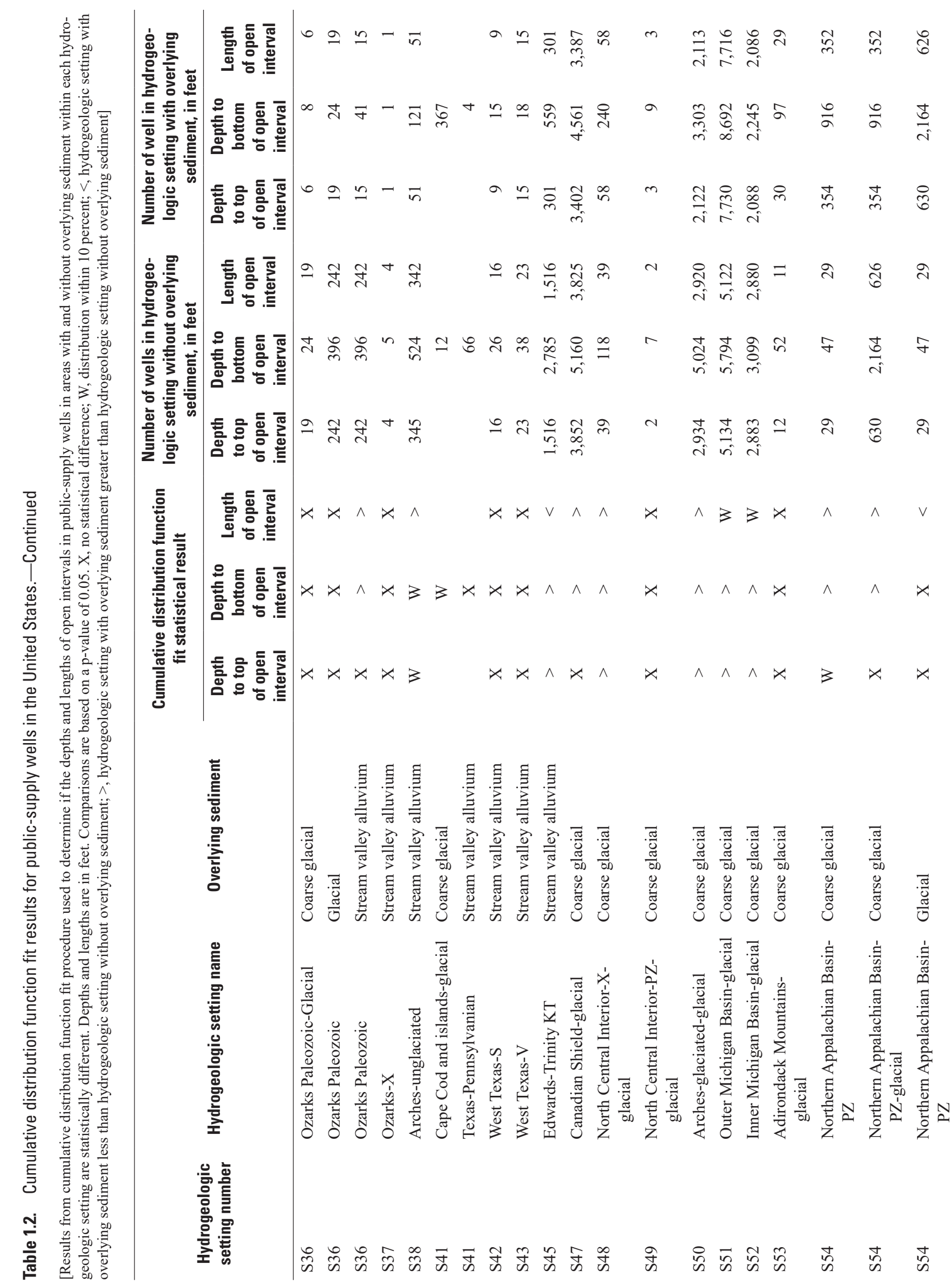




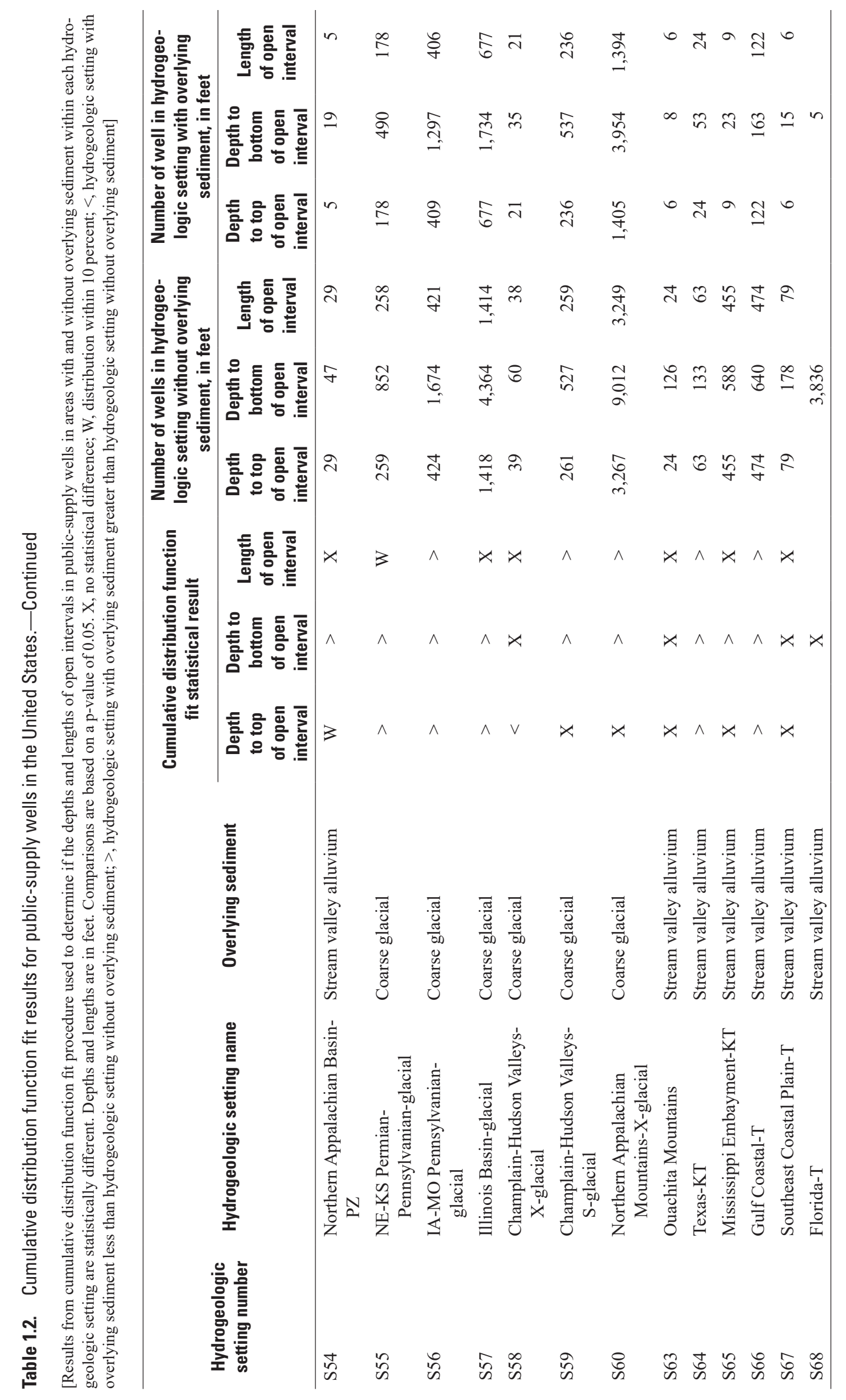




\section{References Cited}

Belitz, K., Watson, E., Johnson, T.D., and Sharpe, J.B., 2019, Secondary hydrogeologic regions of the conterminous United States: Ground Water, v. 57, no. 3, p. 367-377, accessed March 19, 2021, at https://doi.org/10.1111/ gwat.12806.

Lovelace, J.K., Nielsen, M.G., Read, A.L., Murphy, C.J., and Maupin, M.A., 2020, Estimated groundwater withdrawals from principal aquifers in the United States, 2015 (ver. 1.2, October 2020): U.S. Geological Survey Circular 1464, 70 p., accessed March 19, 2021, at http://doi.org/ 10.3133/cir1464. 

For more information, contact

Director, New England Water Science Center

U.S. Geological Survey

10 Bearfoot Road

Northborough, MA 01532

dc_nweng@usgs.gov

or visit our website at

https://www.usgs.gov/centers/new-england-water

Publishing support provided by the Lafayette, Pembroke, and Tacoma Publishing Service Centers. 
